\title{
Influence of Machine-Derived Smoke Yields on Biomarker of Exposure (BOE) Levels in Cigarette Smokers *
}

\author{
by \\ Gerhard Scherer \\ ABF Analytisch-Biologisches Forschungslabor GmbH, Goethestraße 20, 80336 München, Germany
}

\section{CONTENTS}

Summary.

Zusammenfassung.

Resumé

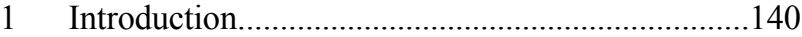

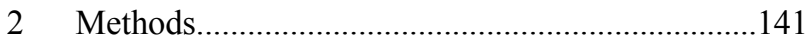

2.1 Selection of suitable publications...........................141

2.2 Statistical evaluations..............................................141

3 Characterization of biomarkers of exposure (BOEs) 141

3.1 Biomarkers for nicotine.........................................141

3.2 Biomarkers for carbon monoxide (CO) and hydrogen cyanide $\mathrm{HCN})$................................................... 142

3.3 Biomarkers for tobacco-specific nitrosamines (TSNAs)

3.4 Biomarkers for polycyclic aromatic hydrocarbons (PAHs).

3.5 Mercapturic acids (MAs) and trans,trans-muconic acid (ttMA).

3.6 Bulk biomarkers................................................. 143

3.7 Protein adducts.......................................................143

4 Association between BOE levels and yields and/or cigarettes per day (CPD)......................................... 144

4.1 Bivariate analysis................................................. 144

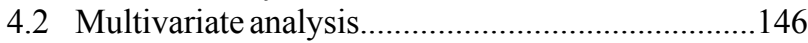

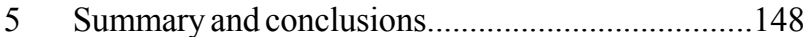

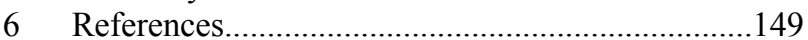

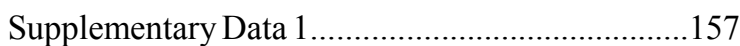

Supplementary Data 2 ...........................................162

\section{SUMMARY}

Individual uptake of tobacco smoke constituents by smoking is highly variable in cigarette smokers and cannot be predicted by smoking behaviour variables and machinederived smoke yields. It is well established that uptake of smoke constituents is best described by a series of biomarkers of exposure (BOEs) such as metabolites of nicotine, tobacco-specific nitrosamines (TSNAs), polycyclic aromatic hydrocarbons (PAHs), aromatic amines, benzene, 1,3-butadiene, acrolein, hydrogen cyanide, 2,5-dimethylfuran and other smoke constituents.

The purpose of this review is to investigate the relationship between BOE levels and machine-derived smoking yields on the basis of published data. The influence of other smoking behaviour variables, in particular the number of cigarettes smoked per day (CPD) and smoking topography (puffing and inhalation patterns) is also considered, provided suitable data are available.

Twenty eight (28) published studies, which report data on machine-derived smoke yields and biomarker concentrations in body fluids of smokers of these products were identified. In total, 33 different BOEs were applied in these studies. Important properties of the BOEs used in the further evaluation were described and discussed.

In almost all studies selected, data for CPD were reported. In only a few studies, puffing and inhalation profiles have been determined so that no systematic evaluation of the association between smoking topography and BOE levels was possible. In the studies evaluated, no statistically 
significant association between daily cigarette consumption (CPD) and smoke yields was observed. This clearly indicates that low machine-derived yields were not compensated by increasing the daily cigarette consumption. As expected, positive and statistically significant relationships were found between CPD and BOE levels for most of the biomarkers investigated.

$\mathrm{Bi}$ - and multivariate linear regressions were calculated for the relationships between BOE levels (dependent variable) and machine-derived yields as well as CPD (independent variables). Whenever possible, results from various studies were combined (this was only possible, when identical biomarkers and yield types were available). Aggregation of the results from all studies independent of BOE and yield type used is feasible on the basis of relative BOE and yield levels. The multivariate linear regression models obtained reveal that both CPD and machine-derived yields are significant predictors of the measured BOE levels. The models predict that, on average, a $50 \%$ reduction in CPD or yield are accompanied by a 33 or $15 \%$ reduction, respectively, in smoke uptake, as measured by various BOEs.

Taken together, the evaluated data from the literature show that lower machine-derived yields lead to a reduced uptake of smoke constituents. The reduction is statistically significant, but substantially lower than the decrease in machinederived yields. [Beitr. Tabakforsch. Int. 26 (2014) 138-175]

\section{ZUSAMMENFASSUNG}

Die individuelle Aufnahme von Tabakrauchbestandteilen durch Zigarettenrauchen variiert stark und kann nicht durch Rauchverhaltensparameter und Maschinenabrauchwerte vorausberechnet werden. Es gilt als gut belegt, dass die Aufnahme von Rauchbestandteilen am besten durch Expositionsbiomarker (BOEs) wie Metaboliten von Nikotin, tabakspezifischen Nitrosaminen (TSNAs), polyzyklischen aromatischen Kohlenwasserstoffen (PAHs), aromatischen Aminen, Benzol, 1,3-Butadien, Acrolein, Blausäure, 2,5Dimethylfuran und anderen Rauchinhaltsstoffen bestimmt werden kann.

Ziel dieses Reviews ist es, auf Basis von Literaturdaten, den Zusammenhang zwischen der Konzentration von BOEs und Maschinenabrauchwerten zu untersuchen. Der Einfluss von Rauchverhaltensparametern, insbesondere die Anzahl der gerauchten Zigaretten pro Tag (CPD) und der Rauchtopographie (Zug- und Inhalationsmuster) wurde dabei berücksichtigt, sofern entsprechende Daten berichtet wurden. Es konnten 28 publizierte Studien identifiziert werden, die Maschinenabrauchwerte und dazugehörige Biomarkerkonzentrationen in Körperflüssigkeiten von Rauchern berichten. Insgesamt wurden 33 verschiedene BOEs bei diesen Untersuchungen verwendet. Maßgebliche Eigenschaften der in diesem Review verwendeten BOEs werden beschrieben und diskutiert.

In fast allen ausgewählten Studien wurden CPD-Werte berichtet. Nur in wenigen Untersuchungen wurden dagegen Zug- und Inhalationsparameter ermittelt, so dass keine systematische Auswertung des Zusammenhangs zu den gemessenen BOE-Spiegeln möglich war. Die Daten der ausgewerteten Studien zeigen keinen statistisch signifikan- ten Zusammenhang zwischen dem täglichen Zigarettenkonsum (CPD) und den maschinellen Abrauchwerten der Zigaretten. Dies weist deutlich darauf hin, dass geringe Maschinenabrauchwerte nicht durch Erhöhung des Zigarettenkonsums kompensiert werden. Erwartungsgemäß wurde ein signifikanter Zusammenhang zwischen CPD und den Konzentrationen der meisten untersuchten BOE gefunden.

Es wurden bi- und multivariate Regressionsanalysen für die BOE-Konzentrationen (abhängige Variable) und die Maschinenabrauchwerte sowie CPD-Daten (unabhängige Variablen) durchgeführt. Wenn möglich wurden die Daten aus verschiedenen Studien für die Auswertung kombiniert (dies war nur möglich, wenn Daten für identische Biomarker und entsprechende Rauchinhaltsstoffe zur Verfügung standen). Durch die Verwendung von relativen Werten für die BOE-Konzentrationen und die Abrauchwerte ist jedoch die Aggregation der Daten aller ausgewählten Studien möglich. Die berechneten multivariaten linearen Regressionsmodelle zeigen, dass CPD und Maschinenabrauchwerte signifikante Prädiktoren für die gemessenen BOE-Spiegel sind. Die ermittelten Modelle sagen voraus, dass eine 50\%-ige Reduktion des täglichen Zigarettenkonsums (CPD) oder des Abrauchwertes im Durchschnitt zu einer 33 bzw. 15\%-igen Abnahme der durch die BOEs gemessenen Rauchaufnahmemenge führt. Zusammenfassend zeigen die ausgewerteten Literaturdaten, dass das Rauchen von Zigaretten mit niedrigeren maschinellen Abrauchwerten mit einer geringeren Aufnahme von Rauchinhaltsstoffen verbunden ist. Die Abnahme ist statistisch signifikant, jedoch deutlich geringer als die nominelle Abnahme in den Maschinenabrauchwerten. [Beitr. Tabakforsch. Int. 26 (2014) 138-175]

\section{RESUME}

L'inhalation individuelle de composants de la fumée de tabac en fumant est hautement variable chez les fumeurs de cigarettes et ne peut pas être prédite par des variables de comportement de fumage et des rendements de fumée obtenus par machine. Il est bien établi que l'inhalation de composants de fumée est décrite au mieux par une série de biomarqueurs d'exposition (BOE) comme les métabolites de la nicotine, les nitrosamines spécifiques du tabac, les hydrocarbures aromatiques polycycliques, les amines aromatiques, le benzène, le buta-1,3-diène, l'acroléine, le cyanure d'hydrogène, le 2,5-diméthylfurane et autres composants de la fumée.

L'objectif de ce compte rendu est d'examiner la relation entre les niveaux de BOE et les rendements de fumée par machine sur la base des données publiées. L'influence d'autres variables du comportement de fumage, en particulier le nombre de cigarettes fumées par jour (CPJ) et la topographie de fumage (production de bouffées et pratiques d'inhalation) est également considérée dans la mesure où des données adaptées sont disponibles.

Vingt-huit (28) études publiées, qui rapportent des données concernant des rendements de fumage par machine et des concentrations de biomarqueurs dans les fluides corporels de fumeurs de ces produits ont été identifiées. Au total, 33 BOE différents ont été appliqués dans ces études. Des 
propriétés importantes des BOE utilisés dans l'évaluation plus approfondie ont été décrites et discutées.

Dans presque toutes les études sélectionnées, des données relatives à la CPJ ont été rapportées. Dans seulement quelques études, des profils de production de bouffées et de pratiques d'inhalation ont été déterminés de sorte qu'aucune évaluation systématique de la relation entre la topographie de fumage et les niveaux de BOE n'était possible. Dans les études évaluées, aucune relation significative entre la consommation de cigarettes par jour (CPJ) et les rendements de fumée n'a été observée. Cela montre clairement que les faibles rendements obtenus par machine n'étaient pas compensés par l'augmentation de la consommation quotidienne de cigarettes. Comme prévu, des relations positives et significatives sur le plan statistique ont été trouvées entre la $\mathrm{CPJ}$ et les niveaux de $\mathrm{BOE}$ pour la plupart des biomarqueurs étudiés.

Des régressions linéaires bivariables et multivariables ont été calculées pour les relations entre les niveaux de BOE (variable dépendante) et des rendements obtenus par machine ainsi que la CPJ (variables indépendantes). Lorsque cela était possible, des résultats de différentes études ont été combinés (ceci était uniquement possible lorsque des biomarqueurs et des types de rendement identiques étaient disponibles). Une agrégation des résultats de toutes les études indépendamment des types de BOE et de rendement utilisés est faisable sur la base de niveaux relatifs de $\mathrm{BOE}$ et de rendement. Les modèles de régression linéaire multivariable obtenus révèlent que la CPJ et les rendements obtenus par machine sont des indicateurs significatifs des niveaux de BOE mesurés. Les modèles prévoient qu'en moyenne, une réduction de $50 \%$ de la CPJ ou du rendement s'accompagne d'une réduction de $33 \%$ ou de $15 \%$ respectivement, dans l'inhalation de fumée, conformément aux mesures effectuées pour divers BOE.

Prises dans leur ensemble, les données publiées évaluées montrent que des rendements plus faibles par machine entraînent une inhalation réduite des composants de fumée.
La réduction est significative sur le plan statistique, mais nettement inférieure à la baisse dans les rendements par machine. [Beitr. Tabakforsch. Int. 26 (2014) 138-175]

\section{$1 \quad$ INTRODUCTION}

The smoking dose in cigarette smokers, apart from duration of smoking, is an important parameter for estimating the implicated health risks with the smoking habit (1-3). The uptake of smoke constituents is highly variable and depends on a number of parameters, which the smoker has the ability to adjust according to his/her requirements. These 'smoking dose adjustment parameters' include (4-6):

- Number of cigarettes smoked per day (CPD)

- Selection of brand according to nominal smoke yield

- Number of puffs per cigarette

- Puff interval (puff frequency)

- Puff volume

- Duration of puff

- Flow rate during puffing

- Amount of smoking expelled from the mouth ('mouth spill')

- Depth of inhalation

- Duration of inhalation

- Butt length

- Blocking of filter vents

It is well established that the number of cigarettes smoked per day (CPD) is an important predictor for the smoking dose (7-9). CPD can be easily assessed by means of questionnaires, however, the self-reported information might be of limited reliability $(10,11)$. Puffing and inhalation intensities are also important for varying the smoking dose (12-16). These parameters are more difficult to assess compared to the CPD information. In addition, measurement of the smoking topography may interfere and modify the natural smoking process (17).

The human smoking dose (also termed 'human smoking

\begin{tabular}{|c|c|c|c|}
\hline \multicolumn{4}{|c|}{ ABBREVIATIONS } \\
\hline 1-OH-Pyr & 1-Hydroxypyrene & NAT & $N$-Nitrosoanatabine \\
\hline $\mathrm{B}[\mathrm{a}] \mathrm{P}$ & Benzo[a]yprene & Nic & Nicotine \\
\hline $\mathrm{BOE}(\mathrm{s})$ & Biomarker(s) of exposure & $\mathrm{Nic}+5$ & 'Nicotine equivalents' (molar sum of nicotine \\
\hline CEVal & $\begin{array}{l}\text { 2-Cyanoethylvaline (hemoglobin adduct of } \\
\text { acrylonitrile) }\end{array}$ & & $\begin{array}{l}\text { and } 5 \text { major metabolites including cotinine, } \\
\text { trans-3'-hydroxycotinine and the three }\end{array}$ \\
\hline $\mathrm{CO}$ & Carbon monoxide & & respective glucuronides) \\
\hline COex & Carbon monoxide in exhaled air & NNAL & 4-(Methylnitrosamino)-1-(3-pyridyl)-1-butanol \\
\hline $\mathrm{COHb}$ & Carboxyhemoglobin & NNK & 4-(Methylnitrosamino)-1-(3-pyridyl)-1- \\
\hline \multirow[t]{3}{*}{ CORESTA } & Centre de Coopération pour les & & butanone \\
\hline & Recherches Scientifiques Relatives au & NNN & $N$-Nitrosonornicotine \\
\hline & Tabac & NS & Non-smokers \\
\hline CPD & Cigarettes per day & $\mathrm{OH}-\mathrm{Cot}$ & trans-3'-Hydroxycotinine \\
\hline CS & Cigarette smokers & OHEtVal & 2-Hydroxyethylvaline (hemoglobin adduct of \\
\hline DHBMA & Dihydroxybutyl-mercapturic acid & & ethylene oxide) \\
\hline ETS & Environmental tobacco smoke & $\mathrm{OH}-\mathrm{PAH}$ & Phenolic polycyclic aromatic hydrocarbons \\
\hline FTC & Federal Trade Commission (USA) & $\mathrm{PAH}(\mathrm{s})$ & Polycyclic aromatic hydrocarbon(s) \\
\hline $\mathrm{HAA}(\mathrm{s})$ & Heterocyclic aromatic amines & PS & Passive smokers \\
\hline $\mathrm{MA}(\mathrm{s})$ & Mercapturic acid(s) & SCN & Thiocyanate \\
\hline \multirow[t]{2}{*}{ MeVal } & Methylvaline (hemoglobin adducts of & SPMA & S-Phenyl-mercapturic acid \\
\hline & methylating agents) & TSNA(s) & Tobacco-specific nitrosamine(s) \\
\hline MHBMA & Monohydroxybutenyl-mercapturic acid & ttMA & trans,trans-Muconic acid \\
\hline NAB & N-Nitrosoanabasine & & \\
\hline
\end{tabular}


yield' or 'yield in use') can be determined by the part filter methodology which has been established and applied in recent years (18-20). This methodology determines only the mouth level exposure but not what is actually absorbed into the body, although both smoking dose variables are strongly correlated $(21,22)$. Another limitation is the fact that each cigarette brand requires its individual calibration for determining the yield in use level.

This restriction is circumvented by measuring biomarkers of exposure (BOEs) in body fluids of smokers (for review, see (23-25)). BOEs for smoke exposure are either unchanged smoke constituents, their metabolites or reaction products with macromolecules (adducts), which reflect the internal exposure dose (26). General limitations of human biomonitoring include the fact that the route of uptake as well as the source of exposure is not known. The latter issue can be circumvented by measuring BOEs to tobacco-specific smoke constituents such as nicotine and tobacco-specific nitrosamines (TSNAs). However, if BOEs for smoke toxicants such as carbon monoxide (CO), polycyclic aromatic hydrocarbon $(\mathrm{PAH})$, aldehydes, hydrogen cyanide $(\mathrm{HCN})$, benzene, etc., which may originate from many sources other than tobacco smoke, are of interest, appropriate study designs are required in order to obtain useful information.

Despite of these restrictions, the measurement of suitable BOEs is nowadays the best approach for assessing the actual smoking dose. Data on BOEs along with information on smoking machine-derived yields and CPD, therefore, provide the basis for investigating the central question of this review:

- What is the relationship between the actual smoking dose and the machine-derived smoke yields of cigarettes?

For this purpose, suitable published studies from the peer reviewed literature were selected. In order to be included in the evaluation, the studies must contain data on machinederived smoke yields (at least two yield levels or ranges of yields (bands)) and the corresponding BOE concentrations in smokers of these products. CPD data for each yield group should be also available (which is the case for all but one of the selected studies). Information on smoking topography was also extracted from the selected studies, but could not be evaluated systematically, since only a few studies provided this information in addition to BOE and yield data. As a general approach for statistical evaluation, linear regressions between BOE and yield levels or CPD as well as between CPD and yield were calculated (bivariate evaluation). In multivariate linear regression analyses, models for $\mathrm{BOE}$ levels (dependent variable) considering yield and CPD as independent variables were also calculated. Whenever possible, data from different studies were aggregated for evaluation.

\section{METHODS}

\subsection{Selection of suitable publications}

For retrieval of suitable publications, the following search items were used:

- Cigarette smoking/cigarette smokers

- Smoking machine-derived yields

- Machine smoking regimes (ISO/FTC/CORESTA/
Health Canada/Massachusetts regime)

- Biomarkers of exposure to smoke constituents, including nicotine, cotinine, other nicotine metabolites, nicotine equivalents, carbon monoxide in exhaled air (COex), carboxyhemoglobin (COHb), thiocyanate, mercapturic acids, hemoglobin adducts

Articles were retrieved from the following sources (databases):

- PubMed database (U.S. National Library of Medicine, National Institutes of Health)

- ABF literature database (contains about 80,000 scientific articles in research fields of smoking, tobacco and related fields)

- References from books/reports/monographs/reviews (3, $4,27-30)$

\subsection{Statistical evaluations}

Linear regressions were calculated using the SPSS Release 13.0 software package (IBM GmbH, Munich, Germany). Regressions were evaluated for the following pairs of dependent/independent variables:

- BOEs/Yields

- BOEs/CPD

- $\mathrm{CPD} /$ Yields

In addition, stepwise linear regression models with $\mathrm{BOE}$ as dependent and yield as well as CPD as independent variables were calculated.

Regression analyses were applied to 8 datasets derived from the 28 selected studies. The datasets are described in detail in Chapter 4.

\section{CHARACTERIZATION OF BIOMARKERS OF EXPOSURE (BOEs)}

Before evaluating the association between BOEs and smoking machine-derived yields and smoking behaviour variables, some important properties of the BOEs of interest have to be considered. Supplementary Data 1 to this review lists the properties of those BOEs, for which data are available for investigating the associations between biomarker levels and mainstream smoke yields. These BOEs will be discussed in the following groups:

- Biomarkers for nicotine

- Biomarkers for carbon monoxide (CO) and hydrogen cyanide $(\mathrm{HCN})$

- Biomarkers for tobacco-specific nitrosamines (TSNAs)

- Biomarkers for polycyclic aromatic hydrocarbons (PAHs)

- Mercapturic acids (MAs) and trans,trans-muconic acid (ttMA)

- Bulk biomarkers

- Protein adducts

\subsection{Biomarkers for nicotine}

Nicotine is usually regarded as tobacco and tobacco smokespecific. Possible interference from other nicotine containing products, such as patches, chewing gums, inhalers and electronic cigarettes has to be considered and, if applicable, eliminated. At low nicotine exposure levels, such as 
exposure of non-smokers to environmental tobacco smoke (ETS), other sources of nicotine, in particular certain food items (31-33) may interfere and need to be considered as well. Nicotine in body fluids has a very short half-life (initial half-life: $8 \mathrm{~min}$; terminal half-life: $2 \mathrm{~h}$ (34)) and, therefore, reflects the acute uptake of nicotine. Thus, application of nicotine as a biomarker in smoking behaviour studies would require strict control of time to last smoking prior to sample collection. Urinary nicotine levels are dependent on the $\mathrm{pH}$ and the urinary flow and are, therefore, relatively variable (34). Nicotine in saliva is a less suitable biomarker, since it originates not only from systemically absorbed nicotine, but also from the exogenous alkaloid in the mouth of the smoker. Additionally, nicotine is actively secreted by the submandibular and parotid salivary glands, which contributes to the high variability of nicotine concentrations in mixed saliva, which is usually collected (35). Therefore, cotinine, rather than nicotine is preferably used as a BOE to nicotine and tobacco or tobacco smoke. In particular, cotinine in blood (plasma or serum) and saliva are highly suitable for this purpose (36). Since cotinine in blood and saliva are strongly correlated, these two biological matrices can be used inter-changeably (37-39). Due to its non-invasive collection, saliva might have advantages for some types of studies. trans-3'-Hydroxycotinine $(\mathrm{OH}-\mathrm{Cot})$ is a further major metabolite of nicotine formed from cotinine. As a $\mathrm{BOE}$ to nicotine it has no advantages over cotinine when taken by itself. However, OH-Cot in body fluids is of interest for phenotyping rapid and slow metabolizers of nicotine by the determination of the $\mathrm{OH}-\mathrm{Cot} /$ cotinine ratio (40-42). Furthermore, OH-Cot and its $O$ - and $\mathrm{N}$-glucuronides represent the major nicotine metabolites in urine. Together with the free and conjugated nicotine and cotinine, these urinary nicotine metabolites constitute about $80 \%$ of the absorbed nicotine dose (also termed 'nicotine equivalents' or ' $\mathrm{Nic}+5$ ') $(34,43,44) . \mathrm{Nic}+5$ has been frequently used as a biomarker for estimating the nicotine dose excreted in the 24-h-urine (21, 45-51). In extension of the Nic +5 method, a Nic +9 method (assessing additionally nornicotine, norcotinine, nicotine- $N$-oxide and cotinine- $N$ oxide) and a Nic +10 method (considering in addition the nicotine metabolite 4-hydroxy-4-(3-pyridyl)-butanoic acid (HyPyBut)) are also available, reflecting about 90 and $98 \%$, respectively, of the total dose of absorbed nicotine (43, 44, 52-55). As yet, however, no data have been published applying these extended methods in studies of interest for this review.

Biomarkers for nicotine, especially cotinine, have been also applied for assessing ETS exposure of non-smokers. Clear dose-response-relationships were observed $(36,56,57)$. This has to be taken into account when the ratio of biomarker levels between cigarette smokers (CS) and nonsmokers (NS) is investigated. This ratio (last column of the table in Supplementary Data 1) is an indicator of the specificity of a biomarker for tobacco smoke exposure. For $\mathrm{BOEs}$ to nicotine, the ratio $\mathrm{CS} / \mathrm{NS}$ is usually $\sim 100$. If the non-smokers are actual passive smokers (PS), the CS/PS ratio can be significantly lower (36). A cutoff for differentiating smokers and non-smokers of about $15 \mathrm{ng} / \mathrm{mL}$ has been proposed (for review, see (44)).

\subsection{Biomarkers for hydrogen cyanide (HCN) and carbon monoxide (CO)}

The first reported biomarker of the (internal) smoking dose was thiocyanate ( $\mathrm{SCN})$, a detoxification product of cyanide, determined in urine, saliva and blood. Claude Bernard (1813-1878) discovered that smokers excreted higher amounts of SCN in their urine than non-smokers $(58,59)$. SCN in body fluids is still in use as a BOE to smokingrelated uptake of hydrogen cyanide, which is one of the strongest toxicants in tobacco smoke. Improved analytical methodology now allows the unambiguous determination of SCN in urine (60), which is not possible with the commonly applied photometric SCN analysis (61). For application of $\mathrm{SCN}$ as a BOE in field studies, a major advantage of this biomarker is its long half-life of $6 \mathrm{~d}$ (62) (other authors reported even half-lives of up to $14 \mathrm{~d}(63)$ ). A substantial disadvantage of $\mathrm{SCN}$ as a $\mathrm{BOE}$ are the relatively high background levels caused by sources for cyanide other than tobacco smoke (almonds, nuts, pulses, bamboo sprouts, beans) and SCN itself (cabbage, cauliflower, broccoli, formation by colon bacteria) (64). This leads to a substantial overlap of the SCN concentration ranges of smokers and non-smokers. The CS/NS ratio is about 2, which plainly emphasizes the described background problem. It should be also mentioned that SCN levels in saliva are about 20 -fold higher than in blood or urine, indicating active transport of SCN from blood into saliva (39).

Carboxyhemoglobin $(\mathrm{COHb})$ has been used as BOE for the smoking-related $\mathrm{CO}$ uptake for almost one century (for review see (64)). $\mathrm{COHb}$ has a half-life of $2-4 \mathrm{~h}$, depending on the physical activity, and, therefore, indicates the acute exposure to $\mathrm{CO}$. There are a couple of other sources for $\mathrm{COHb}$ such as $\mathrm{CO}$ in ambient air (originating mainly from traffic exhausts) and endogenous formation by haem degradation (65). This is reflected in $\mathrm{CS} / \mathrm{NS}$ ratios for $\mathrm{COHb}$ of 4-6 (Supplementary Data 1). A particular property of $\mathrm{COHb}$ is that it reflects smoke inhalation, since $\mathrm{CO}$ can be taken up only through the alveoli (64). CO in exhaled breath is in equilibrium with $\mathrm{COHb}$ in blood. In numerous studies (66-70), strong correlations between $\mathrm{COHb}$ and $\mathrm{CO}$ in exhaled breath (COex) were observed. The non-invasively assessable COex can therefore be used as a fully equivalent surrogate marker for $\mathrm{COHb}$ as a biomarker for $\mathrm{CO}$ uptake.

\subsection{Biomarkers for tobacco-specific nitrosamines (TSNAs)}

The TSNAs include 4-(methylnitrosamino)-1-(3-pyridyl)-1butanone (NNK), $N$-nitrosonornicotine (NNN), $N$-nitrosoanabasine (NAB) and $N$-nitrosoanatabine (NAT). Most human biomonitoring data on TSNA exposure are available for total urinary 4-(methylnitrosamino)-1-(3-pyridyl)-1butanol (NNAL), which is the molar sum of free and conjugated NNAL, representing the major metabolites of NNK in urine. NNAL shows a biphasic elimination from the body with half-lives of about $28 \mathrm{~h}$ and $18 \mathrm{~d}$ for the initial and terminal phases, respectively $(71,72)$. This has to be taken into account in the study design, when using NNAL as a BOE. Total urinary NNAL is also elevated in ETS exposed non-smokers (2). Published CS/NS ratios for NNAL range from $<50$ to $>500$, for which variations in the numerator (NNAL levels in smokers) and the denomi- 
nator (NNAL levels in non-smokers) are responsible (73, 74). Analytical methods for the determination of biomarkers for all four TSNAs (NNAL, NNN, NAB and NAT in urine) have been published $(75,76)$. Sufficient data for evaluating the association between biomarker levels and nominal yields in mainstream smoke of cigarettes are only available for NNAL. It should be also noted that, for unknown reasons, the HPB (4-hydroxy-1-(3-pyridyl)-1butanone)-releasing hemoglobin adducts, which are formed from enzymatically activated NNK and NNN, show no clear dose-response-relationship to tobacco smoke exposure and cannot be used as a BOE (77-80).

\subsection{Biomarkers for polycyclic aromatic hydrocarbons (PAHs)}

PAHs are formed during all incomplete combustion processes of organic materials and comprise more than 500 compounds (81). For characterizing the exposure to this class of compounds, usually only a few representative metabolites are selected. The most frequently used BOE for uptake of PAHs is total (free + conjugated) urinary 1hydroxypyrene (1-OH-Pyr), originating from pyrene exposure (82). More recently, profiles of phenolic metabolites of naphthalene, fluorene, phenanthrene and pyrene have been determined as BOE to PAHs (83-86). Biomarkers for the most studied $\mathrm{PAH}$, benzo $[a]$ pyrene $(\mathrm{B}[a] \mathrm{P})$ include urinary $3-\mathrm{OH}-\mathrm{B}[a] \mathrm{P}(87,88)$ and $\mathrm{B}[a] \mathrm{P}$-tetrol $(89-91)$ as well as either albumin or hemoglobin adducts (92). However, due to the very low BOE levels and hence elaborate analytical procedure required, these methods have not yet been widely applied. The phenolic PAH (OH-PAH) metabolites have elimination half-lives of about $12 \mathrm{~h}$ and can, therefore, be regarded as short-term BOEs. Other sources for exposure to PAHs are smoked, grilled and fried food, leafy vegetables, combustion gases and some topical coal "tar" medications. As a result, there are significant background levels in non-smokers leading to CS/NS ratios of about 2-6 (Supplementary Data 1).

\subsection{Mercapturic acids (MAs) and trans,trans-muconic acid (ttMA)}

MAs in urine are detoxification products originating from various toxicants present in smoke and other environmental media, which are either electrophiles on their own (e.g., acrolein or crotonaldehyde) or metabolically converted to electrophiles (e.g., benzene or 1,3-butadiene). The electrophiles react with the nucleophilic sulfur in glutathione (GSH) and are subsequently metabolized to MAs, which are excreted into urine. Data for evaluation of the association between biomarker levels and mainstream smoke yields are available for S-phenyl-mercapturic acid (SPMA, metabolite of benzene), 3-hydroxypropyl-mercapturic acid (HPMA, metabolite of acrolein), monohydroxybutenyl- and dihydroxybutyl-mercapturic acid (MHBMA and DHBMA, respectively, metabolites of 1,3-butadiene). These MAs have elimination half-lives of about 9-12 h (93) and are thus short-term BOEs. Non-smokers have measurable background levels of these MAs, resulting in CS/NS ratios of about 4-12. Particularly high background concentrations are found for DHBMA $(\mathrm{CS} / \mathrm{NS}$ ratio $<2)$, therefore this metabolite is of limited value as a BOE for the smokingrelated uptake of 1,3-butadiene $(94,95)$.

ttMA is another urinary metabolite of benzene, which is frequently used as a BOE. Despite the fact that a substantial part of the benzene exposure dose is excreted as ttMA into urine (2-25\% for ttMA compared to $0.1-0.5 \%$ for SPMA, (96)), SPMA is a more specific and suitable BOE for the smoking-related benzene uptake than ttMA, with average $\mathrm{CS} / \mathrm{NS}$ ratios of 6.5 and 1.5, respectively (Supplementary Data 1). The reason is that ttMA is also formed as a metabolite from the food preservative sorbic acid, which significantly interferes with ttMA formed from benzene exposure, especially at low exposure levels (96).

\subsection{Bulk biomarkers}

Bulk biomarkers such as urinary thioethers and mutagenic activity indicate the exposure to a class of compounds with similar chemical/toxicological properties such as electrophilic (measured as the sum parameter 'thioethers') and mutagenic chemicals (measured as the sum parameter 'mutagenic activity') (97-99). Thioethers comprise the bulk of all mercapturic acids (MAs) assessable by this methodology (and probably many other sulfur-containing compounds). In terms of elimination half-life, in general the same applies as for urinary MAs. Specificity for tobacco smoke is probably lower than for the MAs mentioned in the previous section, since significant dietary uptake of interfering compounds has to be assumed $(100,101)$. Consequently, the CS/NS ratio for urinary thioether levels is in the range of 1.5 and thus of borderline suitability as a BOE for tobacco smoking. An advantage of this bulk biomarker is undoubtedly the fact that the toxicants (electrophiles) leading to increased thioether levels must not be identified prior to application of this methodology.

Increased urinary mutagenicity in smokers compared to non-smokers was first reported by YAMASAKI and AMES (102). There is a strong influence of diet on the mutagenic activity in urine, therefore, the CS/NS ratio may vary considerably (CS/NS: 10-30), depending on the level of dietary control $(2,27,87)$. The smoking-related urinary mutagenicity reaches non-smoker levels within $6-13 \mathrm{~h}$ after smoking cessation $(103,104)$. Detection of the mutagenic activity is usually performed with the Salmonella typhimurium tester strains TA98 or YG1024 in the presence of a microsomal activation system. The tobacco smokederived mutagens are primarily particle phase constituents (105). Despite some earlier assumptions that heterocyclic aromatic amines (HAA) together with aromatic amines might be mainly responsible for the mutagenic activity of smokers' urine (106-108), recent findings indicate that HAA explain probably only less than $10 \%$ of the mutagenic activity of smoke particles (109). Again, an advantage of this bulk biomarker is the fact that the toxicants (mutagens) leading to increased mutagenic activities must not be identified in order to apply this method.

\subsection{Protein adducts}

Protein adducts can be regarded as a special case of BOEs. They are referred to as 'biomarkers of effective dose', since their formation usually requires metabolic activation of the 
parent compound (110-112). Biomarkers of effective dose, therefore, not only reflect the exposure dose, but also the capacity of the organism to enzymatically activate the compounds of interest to generate the toxic intermediates (e.g., the ultimate carcinogens). Protein adducts for human biomonitoring purposes (most frequently hemoglobin or albumin adducts) are usually of no physiological or toxicological relevance, but rather are used as plain dosimeters, which indicate the accumulated dose over the lifetime of the protein ( $120 \mathrm{~d}$ for hemoglobin, half-life of human serum albumin: $20 \mathrm{~d}$ ). Available data of protein adducts for studying the association between adduct levels and mainstream smoke yields of cigarettes include the following biomarkers: 2-cyanoethylvaline hemoglobin (CEVal, BOE to acrylonitrile), 2-hydroxyethylvaline hemoglobin (OHEtVal, BOE to ethylene oxide and ethylene), methylvaline hemoglobin (MeVal, BOE to methylating agents), carbamoylethylvaline hemoglobin (AAVal, BOE to acrylamide) and 4-aminobiphenyl hemoglobin (4-ABP-Hb, BOE to 4-aminobiphenyl). These adducts reflect the chronic exposure to the smoke toxicants indicated over the last 3-4 months. The adduct with the highest specificity for tobacco smoke is CEVal (CS/NS ratio: 17 (47). The least specific BOE is MeVal (CS/NS ratio: 1.3 (47), primarily owing to substantial endogenous methylation processes. Protein adducts (in particular hemoglobin adducts) are not suitable for short-term studies lasting for several days up to a few weeks. They are, however, ideally suited for longterm field studies lasting for several months up to years (e.g., evaluation of new smoking products in post-market studies $(5,113))$.

\section{ASSOCIATION BETWEEN BOE LEVELS AND YIELDS AND/OR CPD}

In the Supplementary Data 2, data extracted from the 28 selected studies $(9,47,49,50,52,53,83,114-134)$ for the described statistical evaluations are compiled. Each study consists of one or more data sets comprising values for cigarette mainstream smoke yields, BOE levels and CPD. One selected study (116) did not report CPD data. Some studies do not contain separate data for yields, BOEs and $\mathrm{CPD}$, but rather report the results of the correlations and regressions of interest $(9,115,118,122)$. These studies were not included in the evaluations performed for this review, but reported results were listed for information only. Furthermore, in the last column of the table in the Supplementary Data 2 it is indicated, in which statistical evaluations the study data have been used.

In the following two sections (4.1 and 4.2), results of bivariate regressions and multivariate regression models, respectively, are presented. The bivariate evaluation comprises the associations between BOEs and yields, BOE and CPD, as well as CPD and yield. The multivariate evaluation includes linear regression models for BOE (dependent variable) and yield as well as CPD (independent variables). In other words, these models provide quantitative data on how well the BOE levels are predicted by yields and CPDs or how much of the variability in the BOE levels is explained by yield and CPD.

The bivariate associations and the multivariate models are based on the same subsets of selected data from the 28 studies. The characteristics of these datasets are summarized in Table 1.

Aggregation of data with absolute units of BOEs and yields (as is the case with the first 5 datasets in Table 1) requires that the studies to be combined have reported identical (or distinctly convertible) units for the BOEs. Additionally, machine-derived smoke yields of identical smoke components (such as nicotine, "tar", carbon monoxide, or other) have to be used for calculating linear regressions between the variables of interest. Furthermore, the yields have to be determined by identical or similar machine-smoking regimes. For the purpose of this evaluation, the ISO and (former) FTC (US Federal Trade Commission) smoking regimes are regarded to be similar.

The last two datasets of Table 1 are based on relative values for BOEs and yields, allowing the aggregation of data irrespective of the units used for the BOEs and the standard smoking regimes applied for the determination of the yields. The relative dataset with 'corresponding' yields comprises only BOE/yield pairs which are related to the same smoke constituents (e.g., cotinine/nicotine, $\mathrm{COHb} /$ $\mathrm{CO}, \mathrm{NNAL} / \mathrm{NNK}$ ) or BOE/yield pairs with suitable surrogate yields (e.g., NNAL/"tar", OH-PAH/"tar", mutagenic activity/"tar"). The last dataset of Table 1 comprises all available BOE/yield pairs in relative units (\%) from the 24 evaluable studies. Details of the data used for statistical evaluation can be gathered from the Supplementary Data 2. A general limitation of the evaluations presented in this review is the inherent variability of both smoke yield and BOE data, which are generated in different laboratories. While there are analytical standard methods and frequent ring-trials available for smoke yields of "tar", nicotine and $\mathrm{CO}$, this is not the case for analysis of BOEs (although corresponding activities for BOEs are presently driven forth). This limitation has to be kept in mind when interpreting the results.

\subsection{Bivariate analysis}

The associations between smoking behaviour variables such as CPD, puffing and inhalation patterns and the measurable uptake of smoke constituents by BOEs are only a secondary aspect of this review. The selected studies contain information on CPD and other smoking behaviour variables (Supplementary Data 2). In only a few of the studies, results for puffing or inhalation patterns are reported $(9,124,129,133)$. In one study $(133)$, a weak but statistically significant relationship between self-reported inhalation pattern and nicotine uptake was found $(\mathrm{r}=0.20$, $\mathrm{p}=0.002)$. In another study (129), no measurable influence of the extent of inhalation (assessed by questionnaire) on urinary cotinine levels was stated. MUHAMMAD-KAH and coworkers (9) found that important smoking topography parameters were total puff volume, puff count and total inter-puff interval. Together with CPD and yield, these parameters explain about $30-40 \%$ of the variability in daily exposure to nicotine and carbon monoxide. HeE et al. (124) observed that the total puff volume did not significantly change in relation to smoke yields, whereas the inhalation index significantly decreased with increasing yields. In all but one study (116), which were included in the 
Table 1. Datasets considered in the bi- and multivariate evaluations.

\begin{tabular}{|c|c|c|c|c|c|}
\hline Dataset \# & $\begin{array}{l}\text { Biomarker of exposure } \\
\text { (biological matrix) }\end{array}$ & Yield class $^{a}$ & $\begin{array}{l}\begin{array}{l}\text { Number of studies } \\
\text { (references) }\end{array} \\
\end{array}$ & \begin{tabular}{|l|}
$\begin{array}{l}\text { Number of } \\
\text { sub-datasets }\end{array}$ \\
\end{tabular} & $\begin{array}{l}\text { Number of } \\
\text { subjects }\end{array}$ \\
\hline 1 & $\begin{array}{l}\text { Cotinine } \\
\text { (plasma) }\end{array}$ & $\mathrm{N}$ & $\begin{array}{l}7 \\
(49,50,116,117,131,132 \\
134)\end{array}$ & 9 & 6523 \\
\hline 2 & $\begin{array}{l}\text { Cotinine } \\
\text { (saliva) }\end{array}$ & $\mathrm{N}$ & $\begin{array}{l}5 \\
(47,50,52,114,126)\end{array}$ & 5 & 2580 \\
\hline 3 & $\begin{array}{l}\mathrm{Nic}+5 \\
\text { (urine) }\end{array}$ & $\mathrm{N}$ & $\begin{array}{l}3 \\
(47,49,50)\end{array}$ & 3 & 3991 \\
\hline 4 & $\begin{array}{l}\mathrm{COHb} \\
\text { (blood) }\end{array}$ & $\mathrm{CO}$ & $\begin{array}{l}4 \\
(49,124,130,132)\end{array}$ & 6 & 4116 \\
\hline 5 & $\begin{array}{l}\text { COex } \\
\text { (exhaled air) }\end{array}$ & $\mathrm{CO}$ & $\begin{array}{l}2 \\
(119,134)\end{array}$ & 3 & 2726 \\
\hline 6 & $\begin{array}{l}\text { 1-Hydroxypyrene } \\
\text { (urine) }\end{array}$ & "Tar" & $\begin{array}{l}3 \\
(49,120,130)\end{array}$ & 3 & 3707 \\
\hline 7 & $\begin{array}{l}\text { Relative BOE levels } \\
\text { ('corresponding' BOE/yield } \\
\text { pairs) }\end{array}$ & $\begin{array}{l}\text { Relative values of all } \\
\text { 'corresponding' yields }\end{array}$ & $\begin{array}{l}21 \\
(47,49,50,52,53,83,114, \\
116,117,119,120,123,124, \\
126,128-134)\end{array}$ & 24 & 30948 \\
\hline 8 & $\begin{array}{l}\text { Relative BOE levels } \\
\text { (all available BOE/yield pairs) }\end{array}$ & $\begin{array}{l}\text { Relative values of all } \\
\text { available yields }\end{array}$ & $\begin{array}{l}23 \\
(47,49,50,52,53,83,114 \\
116,117,119,120,123-134)\end{array}$ & 27 & 52966 \\
\hline
\end{tabular}

a 'Corresponding yields': yield and biomarker are related to the same chemical in smoke.

b Number of sub-datasets can be higher than number of studies, since some studies comprise more than one data set, for example when males and females were investigated separately or when several biomarkers were evaluated.

c Total numbers of subjects of all studies considered in a subset of data for evaluation. Subjects are multiple counted, if more than one biomarker is evaluated in a study.

evaluation of the relationship between machine-derived smoke yields and biomarker levels, CPD data were reported. In numerous studies, the importance of CPD for the smoking dose as well as the implicated health risks has been emphasized (1-3).

In this bivariate evaluation, the following associations were investigated:

- BOE versus CPD

- BOE versus yield

- CPD versus yield

Table 2 shows the results of this analysis for the 8 selected datasets described in Table 1. These results show that the BOE levels are significantly associated with CPD and with the machine-derived yields for all selected datasets except for \# 3 (nicotine equivalents $\mathrm{Nic}+5$ versus cigarette nicotine yields) and \# 6 (1-hydroxypyrene versus "tar" yield). The latter finding is not surprising, due to the limited number of studies available and the non-specificity of this biomarker for tobacco smoke exposure. The lacking statistical significance for the association between $\mathrm{Nic}+5$ in urine and either CPD or nicotine yield is somewhat unexpected. A number of reasons might have caused this result, including limited number of studies included (only three studies) and the low variability in the CPD variable in the largest of these 3 studies (49).

The association between BOE levels and CPD is in some cases stronger (\# 1, 2, 5), in other cases (\# 4, 7, 8) similar or weaker than the association between BOE levels and yields. This is also somewhat unexpected since in most previous studies $(7,9,118)$ the correlation between $\mathrm{BOE}$ and $\mathrm{CPD}$ was found to be stronger. A plausible explanation for this finding is the fact that in this analysis, average CPD values instead of individual CPDs have to be used for each yield level, thus levelling off the variability in this parameter leading to, in general, weaker correlations. The use of individual CPD data would have been preferable, however, were not available from the published data.

Table 2 further indicates that there is no significant correlation between CPD and machine-derived yield levels, suggesting that the daily cigarette consumption is not increased in smokers of lower yield cigarettes. This observation has been emphasized in an earlier review (4). Also in this evaluation, the above discussed limitation of using average CPD values has to be taken into account.

As an example, the three linear regressions for the selected data base \# 1 are shown in Figures 1-3.

CoUlTAs et al. (118) reported significant coefficients of correlation (r) of 0.51 and 0.52 for the association between salivary cotinine and CPD and between $\mathrm{CO}$ in exhaled breath and CPD, respectively. BENOWITZ et al. (115) found a significant $r$ value of 0.40 between cotinine in plasma and cigarette consumption. MUHAMMAD-KAH et al. (9) concluded from their data that the number of cigarettes smoked per day is the most important factor in the model for predicting nicotine equivalents $(\mathrm{Nic}+5)$ in urine and $\mathrm{COHb}$ levels. Note that these results are based on individual data 
Table 2. Results of the bivariate statistical analysis. Statistically significant coefficients of correlations ( $r$ ) and coefficients of determination $\left(R^{2}\right)$ values are shown in bold.

\begin{tabular}{|c|c|c|c|c|}
\hline $\begin{array}{l}\text { Selected } \\
\text { dataset \# }\end{array}$ & Statistics $^{a}$ & $\begin{array}{c}\text { BOE versus } \\
\text { CPD }\end{array}$ & $\begin{array}{c}\text { BOE versus } \\
\text { yield }\end{array}$ & $\begin{array}{c}\text { CPD versus } \\
\text { yield }\end{array}$ \\
\hline \multirow[t]{4}{*}{1} & $\mathrm{~N}$ & 29 & 31 & 29 \\
\hline & $r$ & 0.858 & 0.559 & 0.343 \\
\hline & $\mathrm{R}^{2}$ & 0.736 & 0.313 & 0.118 \\
\hline & $p$ & 0.000 & 0.001 & 0.069 \\
\hline \multirow[t]{4}{*}{2} & $\mathrm{~N}$ & 23 & 23 & 23 \\
\hline & $r$ & 0.789 & 0.439 & 0.044 \\
\hline & $R^{2}$ & 0.623 & 0.193 & 0.002 \\
\hline & $p$ & 0.000 & 0.036 & 0.841 \\
\hline \multirow[t]{4}{*}{3} & $\mathrm{~N}$ & 10 & 10 & 23 \\
\hline & $r$ & 0.414 & 0.602 & -0.044 \\
\hline & $\mathrm{R}^{2}$ & 0.172 & 0.362 & 0.002 \\
\hline & $p$ & 0.234 & 0.066 & 0.904 \\
\hline \multirow[t]{4}{*}{4} & $\mathrm{~N}$ & 18 & 18 & 18 \\
\hline & $r$ & 0.572 & 0.597 & 0.335 \\
\hline & $\mathrm{R}^{2}$ & 0.327 & 0.356 & 0.112 \\
\hline & $p$ & 0.013 & 0.009 & 0.175 \\
\hline \multirow[t]{4}{*}{5} & $\mathrm{~N}$ & 9 & 9 & 9 \\
\hline & $r$ & 0.944 & -0.084 & -0.337 \\
\hline & $\mathrm{R}^{2}$ & 0.891 & 0.007 & 0.114 \\
\hline & $p$ & 0.000 & 0.830 & 0.375 \\
\hline \multirow[t]{4}{*}{6} & $\mathrm{~N}$ & 9 & 9 & 9 \\
\hline & $r$ & 0.611 & 0.357 & -0.144 \\
\hline & $\mathrm{R}^{2}$ & 0.373 & 0.128 & 0.020 \\
\hline & $p$ & 0.080 & 0.346 & 0.712 \\
\hline \multirow[t]{4}{*}{7} & $\mathrm{~N}$ & 179 & 185 & 179 \\
\hline & $r$ & 0.310 & 0.654 & 0.128 \\
\hline & $\mathrm{R}^{2}$ & 0.096 & 0.428 & 0.016 \\
\hline & $p$ & 0.000 & 0.000 & 0.089 \\
\hline \multirow[t]{4}{*}{8} & $\mathrm{~N}$ & 284 & 292 & 292 \\
\hline & $r$ & 0.207 & 0.505 & 0.033 \\
\hline & $\mathrm{R}^{2}$ & 0.043 & 0.255 & 0.001 \\
\hline & $\mathrm{p}$ & 0.000 & 0.000 & 0.578 \\
\hline
\end{tabular}

a $\mathrm{N}$ : Number of data pairs in the analysis; $r$ : Pearsons coefficient of correlation

for $\mathrm{CPD}$ and BOE levels. Further results for the association between CPD and BOE concentrations have been summarized in an earlier review (4).

GORI and LYNCH (122) stated that CPD is not affected by the FTC nicotine yield of the smoked cigarettes. In a review on smoking behaviour and compensation (4), it was concluded that the number of cigarettes is not a significant factor for compensation. These findings are in agreement with the evaluation presented here, which also shows no significant relationship between CPD and smoke yield levels.

\subsection{Multivariate analysis}

The association between the actual uptake of smoke constituents, measured by suitable biomarkers of exposure (BOEs), and the corresponding machine-derived yields in mainstream smoke of cigarettes is in the focus of this review. Published studies which allow the investigation of this relationship have been especially selected for this purpose (the studies selected are compiled in the Supplementary Data No 2). The BOEs applied in these studies have been characterized and discussed in Chapters 3 and 4.1. The influence of smoking behaviour parameters such as puffing pattern, extent of inhalation and daily cigarette consumption (CPD), as far as these variables were considered in the selected studies, were evaluated in the previous section. CPD was the only smoking behaviour variable, which was included in almost all studies. As found in previous reviews $(4,29)$, nicotine and "tar" yields have no significant impact on average daily cigarette consumption. On the other hand, BOE levels significantly increase with CPD (73, 135-137). Average daily cigarette consumption (CPD) was found to be the strongest predictor for smokingrelated BOE concentrations in body fluids $(9,138)$. It is, therefore, important to take into account the variable $\mathrm{CPD}$ when investigating the association between $\mathrm{BOE}$ and yield levels in cigarette smokers. The consideration of other influencing factors such as gender, age, cigarette blend type, puffing and inhalation profile would be of general interest. However, these influencing factors could not be systematically studied in this review, due to lack of suitable information in the selected studies.

In this section, the results of multivariate analyses of the 8 datasets as described in Table 1 are presented and discussed. Stepwise linear regression models are calculated using the following variables:

- BOE, either with absolute units (datasets \# 1-6) or relative units $(\%$, datasets $\# 7$ and 8$)$ as dependent variable

- CPD, either with absolute units (cigarettes/d, datasets \# 1-6) or in relative units (\%, datasets \# 7 and 8 ) as independent variable

- Smoking machine-derived yields according to ISO or FTC (mg/cigarette, datasets \# 1-6) or in relative units $(\%$, datasets \# 7 and 8$)$ as independent variable.

In Table 3, the characteristics of the various models are summarized. The models generated explain between $95 \%$ (dataset \# 5, COex/CO yield) and 15\% (dataset \# $6,1-\mathrm{OH}-$ pyrene/"tar", not significant) of the variability in the BOE levels. As is obvious from Table 3 , the highest $\mathrm{R}^{2}$ values (indicating the percentage of BOE variability explained) were obtained when $\mathrm{BOE}$ and yield correspond, i.e., are related to the same chemical in tobacco smoke, which is the case for the models based on the datasets \# 1-5. The models based on datasets \# 6-8 partially use 'surrogate' yields in case that the corresponding yields are not available from the published data. Model 8, which uses all available datasets, shows a much lower $\mathrm{R}^{2}$ as compared to Model 7, which uses 'corresponding' or closely related BOE/yield pairs (for further discussion of this issue, see the last but one paragraph of introduction to Chapter 4).

Depending on the selected dataset, the independent variables CPD and yield explain various percentages of the variability in the BOE levels. CPDs explain between 3.6 and $89.2 \%$ of the variability in BOE levels, whereas the corresponding range for yields is $6.2-42.8 \%$. As discussed in Section 4.1, CPD usually is a significantly better predictor for BOE levels than machine-derived yields $(7,9,118)$. We assume that in this particular evaluation, the individual variations in CPD 


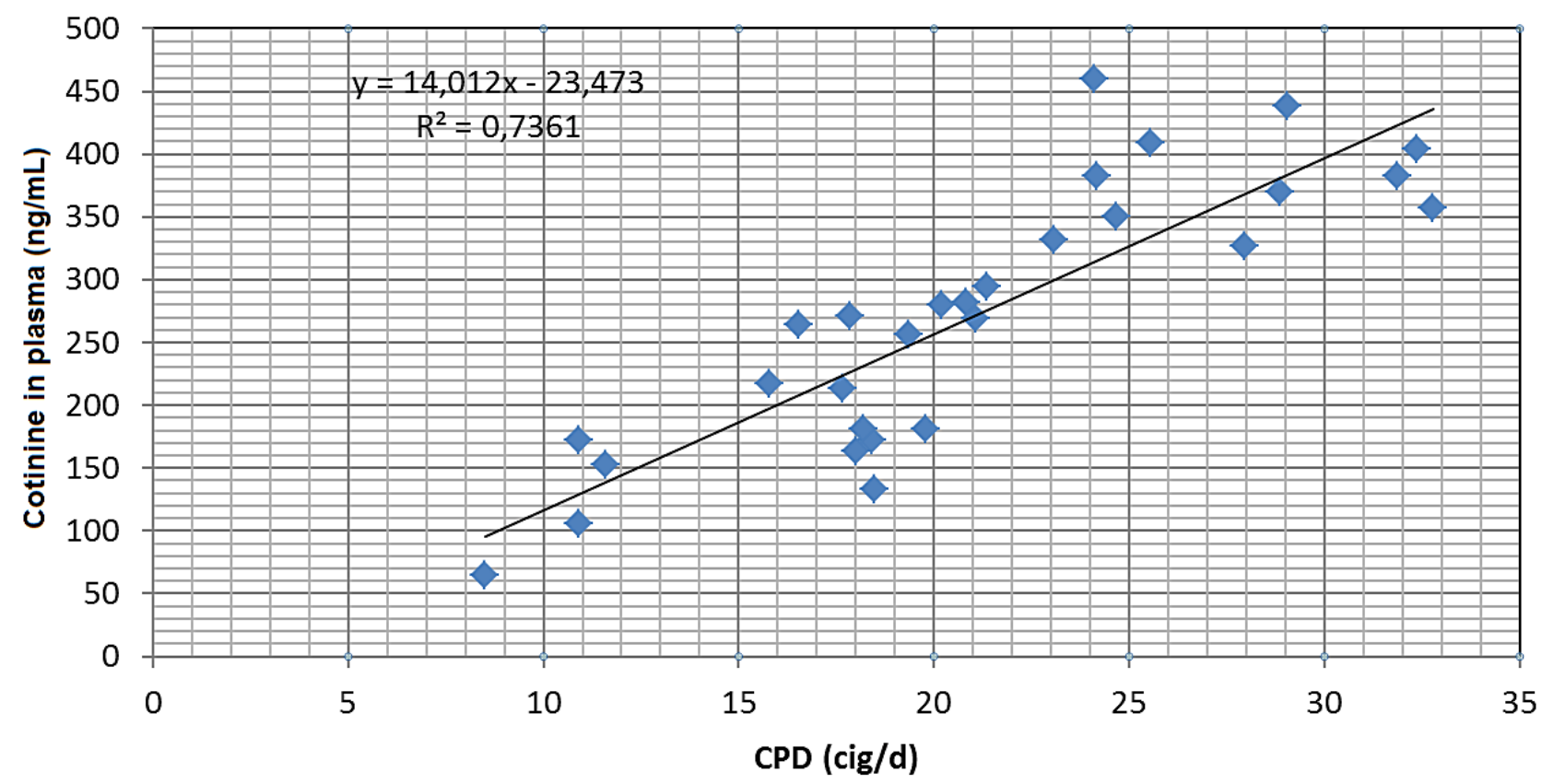

Figure 1. Linear regression between the BOE cotinine in plasma and the average CPD values as extracted from 7 published studies (selected dataset \# 1 in Table 1).

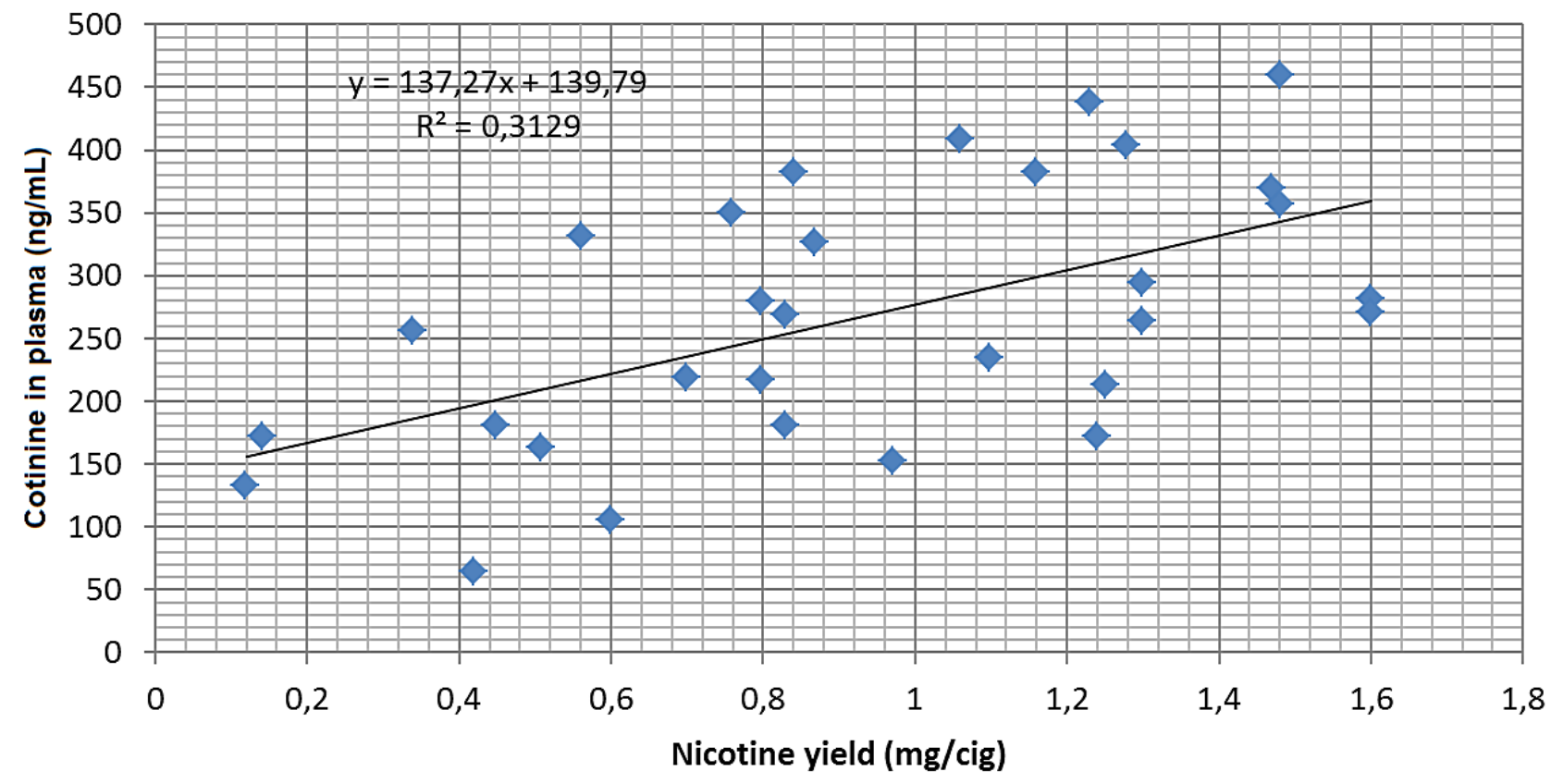

Figure 2. Linear regression between the BOE cotinine in plasma and the smoking machine-derived nicotine yields as extracted from 7 published studies (selected dataset \# 1 in Table 1).

are partly levelled off by using the group means of the CPD, thus possibly leading to lower $\mathrm{R}^{2}$ values for this variable. Model predictions are exemplified in Table 4 . The predicted effects on the BOE levels when reducing either yield or CPD by $50 \%$ and keeping the respective other variable constant were calculated for all models, except for Model 6, which shows no significant contribution of any of the two independent variables. Additionally, this calculation takes into account $95 \%$ confidence intervals (CIs) of the constants and coefficients of the models. The observed CIs were relatively large and show wide overlaps between the various assumed smoking behaviours. Despite of that, the modelderived predictions show some consistent results. The models predict that reducing the daily cigarette consumption (CPD) by $50 \%$ results in an average reduction in BOE levels of $32.6 \%$ (range: $16.3-63.6 \%$ ) when considering the evaluable 7 models (Table 4). The corresponding BOE reductions for a $50 \%$ reduction in machine-derived yields amount to $15.0(4.2-18.9) \%$. This finding is in line with reports of MUHAMMAD-KAH et al. (9), HAMMOND et al. (7), COULTAS et al. (118) who also found that CPD is a significantly better predictor for biomarker-derived smoke uptake 


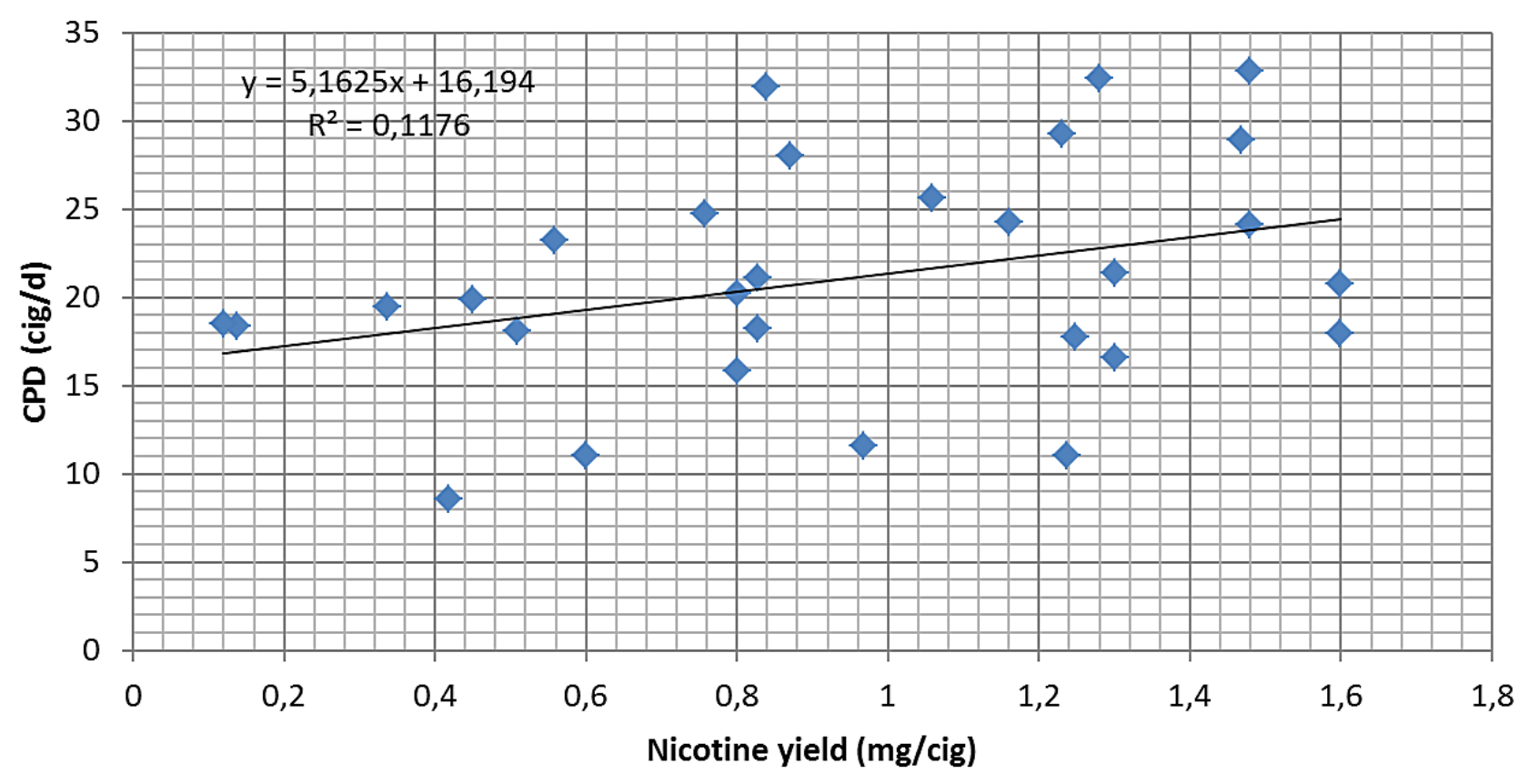

Figure 3. Linear regression between the average CPDs and the smoking machine-derived nicotine yields as extracted from 7 published studies (selected dataset \# 1 in Table 1).

data as compared to machine-derived smoke yields.

In a few studies $(9,115,118,121,122)$, results for the relationship between $\mathrm{BOE}$ and yield levels are presented (summarized in Supplementary Data 2). The reported coefficients of correlation are in the range of -0.15 to 0.23 $(115,118,121,122)$. This would correspond to an explained variability in BOE level by yield of up to $5 \%$, which is significantly lower than the percentage explained by yield found in this evaluation. MUHAMMAD-KAH et al. (9) found that the machine measured "tar" yield was a significant factor in their model for predicting the BOEs $\mathrm{Nic}+5$ and $\mathrm{COHb}$, however with a relatively small contribution to the explained variability in the biomarker levels. This is in agreement with conclusions from other studies (8, $47,49,139)$ and supports the general concept of partial compensation outlined in a previous review (4). However, the extent of this (partial) compensation is still controversial and ranges from $100 \%$ (complete compensation, no association between BOE levels and machine-derived smoke yields) as suggested by some authors (29) and 70\% (slope of $\sim 0.3$ between relative BOE and yield levels) as found in the data evaluation of this review.

\section{SUMMARY AND CONCLUSIONS}

- Twenty eight (28) published studies, which reported data on machine-derived smoke yields of cigarettes and corresponding biomarker concentrations in body fluids of smokers of these products were identified. In total, 33 different BOEs were applied in these studies.

- Important properties of the BOEs applied, such as precursors in smoke, sources other than tobacco smoke, background levels in non-smokers, half-life and smoker/non-smoker level ratios were described and discussed.
Table 3. Results of the multivariate statistical analysis: Model characteristics (stepwise linear regression). Statistically significant independent variables (and constants) in the models are shown in bold.

\begin{tabular}{|c|c|c|c|c|c|}
\hline Dataset \# & $N^{a}$ & & $\mathrm{R}^{2}$ & Significance & Coefficients \\
\hline 1 & 29 & $\begin{array}{l}\text { Model } \\
\text { (Constant) } \\
\text { CPD } \\
\text { Yield }\end{array}$ & $\begin{array}{r}0.818 \\
-\overline{0.736} \\
0.081\end{array}$ & $\begin{array}{r}-\overline{80} \\
0.000 \\
\mathbf{0 . 0 0 2}\end{array}$ & $\begin{array}{r}-\overline{(-57.93)} \\
12.31 \\
74.67\end{array}$ \\
\hline 2 & 23 & $\begin{array}{l}\text { Model } \\
\text { (Constant) } \\
\text { CPD } \\
\text { Yield }\end{array}$ & $\begin{array}{r}0.786 \\
-\overline{-} \\
0.623 \\
0.163\end{array}$ & $\begin{array}{l}-\overline{0} \\
0.081 \\
0.000 \\
\mathbf{0 . 0 0 1}\end{array}$ & $\begin{array}{c}-\overline{(53.10)} \\
9.24 \\
\mathbf{9 8 . 8 4}\end{array}$ \\
\hline 3 & 10 & $\begin{array}{l}\text { Model } \\
\text { (Constant) } \\
\text { CPD } \\
\text { Yield }\end{array}$ & $\begin{array}{r}0.557 \\
- \\
0.195 \\
\mathbf{0 . 3 6 2}\end{array}$ & $\begin{array}{l}-\overline{0} \\
0.643 \\
0.123 \\
\mathbf{0 . 0 4 3}\end{array}$ & $\begin{array}{c}-\overline{(2.190)} \\
0.434 \\
4.725\end{array}$ \\
\hline 4 & 18 & $\begin{array}{l}\text { Model } \\
\text { (Constant) } \\
\text { CPD } \\
\text { Yield }\end{array}$ & $\begin{array}{r}0.706 \\
-\overline{0} \\
0.678 \\
0.029\end{array}$ & $\begin{array}{r}-\overline{0} \\
0.000 \\
0.246\end{array}$ & $\begin{array}{c}-\overline{(2.914)} \\
0.131 \\
0.045\end{array}$ \\
\hline 5 & 9 & $\begin{array}{l}\text { Model } \\
\text { (Constant) } \\
\text { CPD } \\
\text { Yield }\end{array}$ & $\begin{array}{r}0.953 \\
- \\
0.892 \\
0.062\end{array}$ & $\begin{array}{l}-\overline{4} \\
0.044 \\
0.000 \\
0.030\end{array}$ & $\begin{array}{r}-\overline{(11.04)} \\
1.485 \\
0.470\end{array}$ \\
\hline 6 & 9 & $\begin{array}{l}\text { Model } \\
\text { (Constant) } \\
\text { CPD } \\
\text { Yield }\end{array}$ & $\begin{array}{r}0.151 \\
- \\
0.055 \\
0.095\end{array}$ & $\begin{array}{l}-\overline{0} \\
0.458 \\
0.554 \\
0.498\end{array}$ & $\begin{array}{r}- \\
(-297.35) \\
-11.496 \\
8.603\end{array}$ \\
\hline 7 & 179 & $\begin{array}{l}\text { Model } \\
\text { (Constant) } \\
\text { CPD } \\
\text { Yield }\end{array}$ & $\begin{array}{r}0.480 \\
-\overline{-} \\
0.052 \\
0.428\end{array}$ & $\begin{array}{r}-\overline{0} \\
0.209 \\
0.000 \\
\mathbf{0 . 0 0 0}\end{array}$ & $\begin{array}{c}-\overline{(14.430)} \\
\mathbf{0 . 4 9 0} \\
\mathbf{0 . 3 8 7}\end{array}$ \\
\hline 8 & 284 & $\begin{array}{l}\text { Model } \\
\text { (Constant) } \\
\text { CPD } \\
\text { Yield }\end{array}$ & $\begin{array}{r}0.290 \\
-\overline{-} \\
0.036 \\
0.253\end{array}$ & $\begin{array}{r}-\overline{0} \\
0.000 \\
0.000\end{array}$ & $\begin{array}{r}-\overline{(40.127)} \\
0.331 \\
0.280\end{array}$ \\
\hline
\end{tabular}

a $\mathrm{N}$ : Number of data pairs in the analysis 
Table 4. Predicted BOE levels and reductions under various assumed human smoking conditions. The rows indicating the effect of the $50 \%$ yield reduction are shaded in grey.

\begin{tabular}{|c|c|c|c|c|c|c|}
\hline \multirow{2}{*}{$\begin{array}{l}\text { Dataset and model \# } \\
\text { BOEs, yields (units) }\end{array}$} & \multicolumn{3}{|c|}{ Assumed human smoking } & \multicolumn{2}{|c|}{ Predicted BOE level } & \multirow{2}{*}{$\begin{array}{l}\text { Predicted \% reduction } \\
\text { in mean BOE level }\end{array}$} \\
\hline & No & Yield & CPD & Mean & $95 \% \mathrm{Cl}$ & \\
\hline \multirow{4}{*}{$\begin{array}{l}\# 1 \\
\text { BOE: cotinine (P) (ng/ml) } \\
\text { Yield: nicotine (mg/cig) }\end{array}$} & 1 & 1.0 & 15 & 201.4 & $46.2-356.6$ & \multirow{2}{*}{18.5} \\
\hline & 2 & 0.5 & 15 & 164.1 & $31.4-296.8$ & \\
\hline & 3 & 1.0 & 20 & 262.9 & $92.8-433.1$ & \multirow{2}{*}{46.8} \\
\hline & 4 & 1.0 & 10 & 139.8 & $-0.4-280.1$ & \\
\hline \multirow{4}{*}{$\begin{array}{l}\# 2 \\
\text { BOE: cotinine (S) (ng/ml) } \\
\text { Yield: nicotine (mg/cig) }\end{array}$} & 1 & 1.0 & 15 & 290.5 & $138.6-442.3$ & \multirow{2}{*}{17.0} \\
\hline & 2 & 0.5 & 15 & 241.1 & $115.6-366.5$ & \\
\hline & 3 & 1.0 & 20 & 336.7 & $171.9-501.4$ & \multirow{2}{*}{27.4} \\
\hline & 4 & 1.0 & 10 & 244.3 & $105.4-383.2$ & \\
\hline \multirow{4}{*}{$\begin{array}{l}\text { \# } 3 \\
\text { BOE: Nic+5 (U) (mg/24h) } \\
\text { Yield: nicotine (mg/cig) }\end{array}$} & 1 & 1.0 & 15 & 13.4 & $-10.6-37.4$ & \multirow{2}{*}{17.6} \\
\hline & 2 & 0.5 & 15 & 11.1 & $-10.7-32.8$ & \\
\hline & 3 & 1.0 & 20 & 15.5 & $-11.3-42.5$ & \multirow{2}{*}{27.8} \\
\hline & 4 & 1.0 & 10 & 11.3 & $-9.8-32.3$ & \\
\hline \multirow{4}{*}{$\begin{array}{l}\# 4 \\
\text { BOE: COHb (B) (\%) } \\
\text { Yield: CO (mg/cig) }\end{array}$} & 1 & 10.0 & 15 & 5.3 & $1.7-9.1$ & \multirow{2}{*}{4.2} \\
\hline & 2 & 5.0 & 15 & 5.1 & $1.6-8.0$ & \\
\hline & 3 & 10.0 & 20 & 6.0 & $1.7-9.8$ & \multirow{2}{*}{21.9} \\
\hline & 4 & 10.0 & 10 & 4.7 & $1.7-8.4$ & \\
\hline \multirow{4}{*}{$\begin{array}{l}\# 5 \\
\text { BOE: COex (Ex) (ppm) } \\
\text { Yield: CO (mg/cig) }\end{array}$} & 1 & 10.0 & 15 & 15.9 & $-3.7-35.9$ & \multirow{2}{*}{14.7} \\
\hline & 2 & 5.0 & 15 & 13.6 & $-4.0-31.2$ & \\
\hline & 3 & 10.0 & 20 & 23.4 & $2.1-44.7$ & \multirow{2}{*}{63.6} \\
\hline & 4 & 10.0 & 10 & 8.5 & $-9.5-26.5$ & \\
\hline \multirow{4}{*}{$\begin{array}{l}\# 7 \\
\text { Relative BOEs (\%) and } \\
\text { corresponding } \\
\text { relative yields (\%), } \\
\text { relative CPD (\%) }\end{array}$} & 1 & 100.0 & 100 & 102.1 & $49.8-154.5$ & \multirow{2}{*}{18.9} \\
\hline & 2 & 50.0 & 100 & 82.8 & $33.8-131.8$ & \\
\hline & 3 & 100.0 & 100 & 102.1 & $49.8-154.5$ & \multirow{2}{*}{24.0} \\
\hline & 4 & 100.0 & 50 & 77.6 & $36.8-118.4$ & \\
\hline \multirow{4}{*}{$\begin{array}{l}\text { \# } 8 \\
\text { All available } \\
\text { relative BOEs (\%), } \\
\text { relative yields (\%), } \\
\text { relative CPD (\%) }\end{array}$} & 1 & 100.0 & 100 & 101.2 & $61.1-141.4$ & \multirow{2}{*}{13.8} \\
\hline & 2 & 50.0 & 100 & 87.2 & $49.9-124.6$ & \\
\hline & 3 & 100.0 & 100 & 101.2 & $61.1-141.4$ & \multirow{2}{*}{16.3} \\
\hline & 4 & 100.0 & 50 & 84.7 & $53.2-116.2$ & \\
\hline
\end{tabular}

a P: plasma; S: saliva; B: blood; U: urine; Ex: exhaled air; Cl: confidence interval

- In almost all studies, data for CPD were provided. In only a few studies, puffing or inhalation profiles have been determined so that no systematic evaluation of the association between puffing and inhalation variables and BOE levels was possible.

- Stepwise linear regression models were calculated with $\mathrm{BOE}$ as dependent variable and CPD as well as smoking machine-derived yields as independent variables. Depending on the dataset evaluated, both CPD and yield were found as significant predictors for the measurable BOE levels. In previous studies, most frequently CPD was reported to be a significantly better predictor than yield. A possible reason for this discrepancy is that fact that in this evaluation, average CPD values had to be used resulting in loss of variability in this parameter.

- The models predict that reducing the daily cigarette consumption (CPD) by $50 \%$ would result in an average reduction in BOE levels of $33 \%$, whereas a $50 \%$ reduction in machine-derived yields would result in a mean reduction of $15 \%$ reduction in smoke uptake.

\section{ACKNOWLEDGEMENTS}

The financial support for the preparation of this review by Japan Tobacco International, Geneva, Switzerland is gratefully acknowledged. I also thank Professor WolfDieter Heller for support with the statistical analysis.

\section{REFERENCES}

1. Doll, R. and R. Peto: Cigarette Smoking and Bronchial Carcinoma: Dose and Time Relationships among Regular Smokers and Lifelong Non-Smokers; J. Epidemiol. Community Health 32 (1978) 303-313.

2. International Agency for Research on Cancer (IARC): Tobacco Smoke and Involuntary Smoking; IARC Monographs on the Evaluation of Carcinogenic Risks to Humans, Vol 83, IARC, Lyon, France, 2004.

3. U.S. Department of Health and Human Services: How Tobacco Smoke Causes Disease: The Biology and Behavioral Basis for Smoking-Attributable Disease: A Report of the Surgeon General; U.S. Dept. of Health 
and Human Services, Centers for Disease Control and Prevention, National Center for Chronic Disease Prevention and Health Promotion, Office on Smoking and Health, Atlanta, GA, USA, 2010, available at: http://www.surgeongeneral.gov/library (accessed Nov. 2014).

4. Scherer, G.: Smoking Behaviour and Compensation: A Review of the Literature; Psychopharmacology (Berl.) 145 (1999) 1-20.

5. Scherer, G.: Biomonitoring of Inhaled Complex Mixtures - Ambient Air, Diesel Exhaust and Cigarette Smoke; Exp. Toxicol. Pathol. 57 (2005) 75-110.

6. Scherer, G. and P.N. Lee: Smoking Behaviour and Compensation: A Review of the Literature with MetaAnalysis; Regul. Toxicol. Pharmacol. (2014) in press, available at: http://www.sciencedirect.com/science/ article/pii/S027323001400213X (accessed Nov. 2014).

7. Hammond, D., G.T. Fong, K.M. Cummings, and A. Hyland: Smoking Topography, Brand Switching, and Nicotine Delivery: Results from an In Vivo Study; Cancer Epidemiol. Biomarkers Prev. 14 (2005) 1370-1375

8. Hammond, D., G.T. Fong, K.M. Cummings, R.J. O'Connor, G.A. Giovino, and A. McNeill: Cigarette Yields and Human Exposure: A Comparison of Alternative Testing Regimens; Cancer Epidemiol. Biomarkers Prev. 15 (2006) 1495-1501.

9. Muhammad-Kah, R., Q. Liang, K. Frost-Pineda, P.E. Mendes, H.J. Roethig, and M. Sarkar: Factors Affecting Exposure to Nicotine and Carbon Monoxide in Adult Cigarette Smokers; Regul. Toxicol. Pharmacol. 61 (2011) 129-136.

10. Fidler, J.A., J.A. Stapleton, and R. West: Variation in Saliva Cotinine as a Function of Self-Reported Attempts to Reduce Cigarette Consumption; Psychopharmacology (Berl.) 217 (2011) 587-593.

11. Lewis, S.J., N.M. Cherry, R. McL. Niven, P.V. Barber, K. Wilde, and A.C. Povey: Cotinine Levels and Self-Reported Smoking Status in Patients Attending a Bronchoscopy Clinic; Biomarkers 8 (2003) 218-239.

12. Matsumoto, M., Y. Inaba, I. Yamaguchi, O. Endo, D. Hammond, S. Uchiyama, and G. Suzuki: Smoking Topography and Biomarkers of Exposure among Japanese Smokers: Associations with Cigarette Emissions Obtained Using Machine Smoking Protocols; Environ. Health Prev. Med. 18 (2013) 95-103.

13. Hatsukami, D.K., R.W. Pickens, D.S. Svikis, and J.R. Hughes: Smoking Topography and Nicotine Blood Levels; Addict. Behav. 13 (1988) 91-95.

14. Burling, T.A., M.L. Stitzer, G.E. Bigelow, and A.M. Mead: Smoking Topography and Carbon Monoxide Levels in Smokers; Addict. Behav. 10 (1985) 319-323.

15. Burling, T.A., S.B. Lovett, W.T. Richter, and L.W. Frederiksen: Alveolar Carbon Monoxide: The Relative Contributions of Daily Cigarette Rate, Cigarette Brand, and Smoking Topography; Addict. Behav. 8 (1983) 23-26.

16. Pickworth, W., P. Houlgate, M. Schorp, M. Dixon, M. Borgerding, and G. Zaatari: (2005) A Review of Human Smoking Behaviour Data and Recommenda- tions for a New ISO Standard for the Machine Smoking of Cigarettes; available at: http://legacy.library. ucsf.edu/tid/bqa92g00/pdf, Bates-No. 30837479478050 (accessed Nov. 2014).

17. Ossip-Klein, D.J., J.E. Martin, B.D. Lomax, D.M. Prue, and C.J. Davis: Assessment of Smoking Topography Generalization across Laboratory Clinical, and Naturalistic Settings; Addict. Behav. 8 (1983) 11-17.

18. Mariner, D.C., M. Ashley, C.J. Shepperd, G. Mullard, and M. Dixon: Mouth Level Smoke Exposure Using Analysis of Filters from Smoked Cigarettes: A Study of Eight Countries; Regul. Toxicol. Pharmacol. 61 (Suppl 3) (2011) S39-S50.

19. Shepperd, C.J., F.K. St Charles, M. Lien, and M. Dixon: Validation of Methods for Determining Consumer Smoked Cigarette Yields from Cigarette Filter Analysis; Beitr. Tabakforsch. Int. 22 (2006) 176-184.

20. St Charles, F.K., M. Ashley, C.J. Shepperd, P. Clayton, and G. Errington: A Robust Method for Estimating Human Smoked Cigarette Yields from Filter Analysis Data; Beitr. Tabakforsch. Int. 23 (2009) 232-243.

21. Morin, A., C.J. Shepperd, A.C. Eldridge, N. Poirier, and R. Voisine: Estimation and Correlation of Cigarette Smoke Exposure in Canadian Smokers as Determined by Filter Analysis and Biomarkers of Exposure; Regul. Toxicol. Pharmacol. 61 (Suppl 3) (2011) S3-S12.

22. Shepperd, C.J., A.C. Eldridge, D.C. Mariner, M. McEwan, and M. Dixon: A Study to Estimate and Correlate Cigarette Smoke Exposure in Smokers in Germany as Determined by Filter Analysis and Biomarkers of Exposure; Regul. Toxicol. Pharmacol. 55 (2009) 97-109.

23. Scherer, G.: Tobacco Smoke: Methodology for Assessing the Exposure; Cent. Eur. J. Occup. Environ. Med. 11 (2005) 102-122.

24. Scherer, G.: Application of Biomarkers for the Evaluation of Potential Reduced-Exposure Products (PREPs); Rec. Adv. Tob. Sci. 32 (2006) 85-122.

25. Gregg, E.O., E. Minet, and M. McEwan: Urinary Biomarkers of Smokers' Exposure to Tobacco Smoke Constituents in Tobacco Products Assessment: A Fit for Purpose Approach; Biomarkers 18 (2013) 467-486.

26. Angerer, J., U. Ewers, and M. Wilhelm: Human Biomonitoring: State of the Art; Int. J. Hyg. Environ. Health 210 (2007) 201-228.

27. International Agency for Research on Cancer (IARC): Tobacco Smoking; IARC Monographs on the Evaluation of the Carcinogenic Risk of Chemicals to $\mathrm{Hu}-$ mans, Vol. 38, IARC, Lyon, France, 1986.

28. Institute of Medicine (IOM): Clearing the Smoke: Assessing the Science Base for Tobacco Harm Reduction; edited by K. Stratton, P. Shetty, R. Wallace, and S. Bondurant, National Academy Press, Washington, DC, USA, 2001.

29. Benowitz, N.L.: Compensatory Smoking of LowYield Cigarettes; in: Risks Associated with Smoking Cigarettes with Low Machine-Measured Yields of Tar and Nicotine; Smoking and Tobacco Control Monograph 13, U.S. Dept. of Health and Human Services, 
Public Health Service, National Institutes of Health, National Cancer Institute, NIH Publication, Bethesda, MD, USA, 2001, pp. 39-63.

30. U.S. Dept. of Health and Human Services, Public Health Service, National Institutes of Health, National Cancer Institute: Risks Associated with Smoking Cigarettes with Low Machine-Measured Yields of Tar and Nicotine; Smoking and Tobacco Control Monograph 13, NIH Publication, Bethesda, MD, USA, 2001.

31. Castro, A. and N. Monji: Dietary Nicotine and its Significance in Studies on Tobacco Smoking; Biochem. Arch. 2 (1986) 91-97.

32. Davis, R.A., M.F. Stiles, J.D. deBethizy, and J.H. Reynolds: Dietary Nicotine: A Source of Urinary Cotinine; Food Chem. Toxicol. 29 (1991) 821-827.

33. Sheen, S.J.: Detection of Nicotine in Foods and Plant Materials; J. Food Sci. 53 (1988) 1572-1573.

34. Davis, R.A. and M. Curvall: Determination of Nicotine and its Metabolites in Biological Fluids: In Vivo Studies; in: Analytical Determination of Nicotine and Related Compounds and Their Metabolites, edited by J.W. Gorrod and P. Jacob III, Elsevier, Amsterdam, The Netherlands, 1999, pp. 583-643.

35. Jarczyk, L., H. Maier, I.A. Born, G. Scherer, and F. Adlkofer: Concentration of Nicotine in Serum and Saliva after Intravenous Infusion of the Alkaloid and after Smoking; in: Effects of Nicotine on Biological Systems, edited by F. Adlkofer and K. Thurau, Birkhäuser Verlag, Basel, Switzerland, 1991, pp 51-55.

36. Lee, P.N.: Uses and Abuses of Cotinine as a Marker of Tobacco Smoke Exposure; in: Nicotine and Related Compounds and Their Metabolites, edited by J.W. Gorrod and P. Jacob III, Elsevier, Amsterdam, The Netherlands, 1999, pp 669-719.

37. Curvall, M., C.E. Elwin, E. Kazemi-Vala, C. Warholm, and C.R. Enzell: The Pharmacokinetics of Cotinine in Plasma and Saliva from Non-Smoking Healthy Volunteers; Eur. J. Clin. Pharmacol. 38 (1990) 281-287.

38. Jarvis, M.J., P. Primatesta, B. Erens, C. Feyerabend, and A. Bryant: Measuring Nicotine Intake in Population Surveys: Comparability of Saliva Cotinine and Plasma Cotinine Estimates; Nicotine Tob. Res. 5 (2003) 349-355.

39. Michalke, B., B. Rossbach, T. Göen, A. Schäferhenrich, and G. Scherer: Saliva as a Matrix for Human Biomonitoring in Occupational and Environmental Medicine; Int. Arch. Occup. Environ. Health, epub ahead of print (2014), available at: http://link.springer. com/article/10.1007\%2Fs00420-014-0938-5 (accessed Nov. 2014)

40. Benowitz, N.L., G.E. Swan, P. Jacob III, C.N. LessovSchlaggar, and R.F. Tyndale: CYP2A6 Genotype and the Metabolism and Disposition Kinetics of Nicotine; Clin. Pharmacol. Ther. 80 (2006) 457-467.

41. Malaiyandi, V., S.D. Goodz, E.M. Sellers, and R.F. Tyndale: CYP2A6 Genotype, Phenotype, and the Use of Nicotine Metabolites as Biomarkers during Smoking; Cancer Epidemiol. Biomarkers Prev. 15 (2006) 1812-1819.

42. West, O., P. Hajek, and H. McRobbie: Systematic
Review of the Relationship Between the 3-Hydroxycotinine/Cotinine Ratio and Cigarette Dependence; Psychopharmacology (Berl.) 218 (2011) 313-322.

43. Curvall, M., E. Kazcemi Vala, C.R. Enzell, and J. Wahren: Simulation and Evaluation of Nicotine Intake During Passive Smoking: Cotinine Measurements in Body Fluids of Nonsmokers Given Intravenous Infusions of Nicotine; Clin. Pharmacol. Ther. 47 (1990) 42-49.

44. Tricker, A.R.: Biomarkers Derived from Nicotine and its Metabolites: A Review; Beitr. Tabakforsch. Int. 22 (2006) 147-175.

45. Zedler, B.K., R. Kinser, J. Oey, B. Nelson, H.J. Roethig, R.A. Walk, P. Kuhl, K. Rustemeier, G. Schepers, K. von Holt, and A.R. Tricker: Biomarkers of Exposure and Potential Harm in Adult Smokers of 3-7 mg Tar Yield (Federal Trade Commission) Cigarettes and in Adult Non-Smokers; Biomarkers 11 (2006) 201-220.

46. Feng, S., S. Kapur, M. Sarkar, R. Muhammad, P. Mendes, K. Newland, and H.J. Roethig: Respiratory Retention of Nicotine and Urinary Excretion of Nicotine and its Five Major Metabolites in Adult Male Smokers; Toxicol. Lett. 173 (2007) 101-106.

47. Scherer, G., J. Engl, M. Urban, G. Gilch, D. Janket, and K. Riedel: Relationship Between Machine-Derived Smoke Yields and Biomarkers in Cigarette Smokers in Germany; Regul. Toxicol. Pharmacol. 47 (2007) 171-183.

48. Roethig, H.J., S. Feng, Q. Liang, J. Liu, W.A. Rees, and B.K. Zedler: A 12-Month, Randomized, Controlled Study to Evaluate Exposure and Cardiovascular Risk Factors in Adult Smokers Switching from Conventional Cigarettes to a Second-Generation Electrically Heated Cigarette Smoking System; J. Clin. Pharmacol. 48 (2008) 580-591.

49. Mendes, P., Q. Liang, K. Frost-Pineda, S. Munjal, R.A. Walk, and H.J. Roethig: The Relationship Between Smoking Machine Derived Tar Yields and Biomarkers of Exposure in Adult Cigarette Smokers in the US; Regul. Toxicol. Pharmacol. 55 (2009) 17-27.

50. Shepperd, C.J., A.C. Eldridge, G. Errington, and M. Dixon: A Study to Evaluate the Effect on Mouth Level Exposure and Biomarkers of Exposure Estimates of Cigarette Smoke Exposure Following a Forced Switch to a Lower ISO Tar Yield Cigarette; Regul. Toxicol. Pharmacol. 61 (2011) (Suppl. 3) S13-S24.

51. Sarkar, M., R. Muhammad-Kah, Q. Liang, S. Kapur, S. Feng, and H. Roethig: Evaluation of Spot Urine as an Alternative to $24 \mathrm{~h}$ Urine Collection for Determination of Biomarkers of Exposure to Cigarette Smoke in Adult Smokers; Environ. Toxicol. Pharmacol. 36 (2013) 108-114.

52. Byrd, G.D., R.A. Davis, W.S. Caldwell, J.H. Robinson, and J.D. deBethizy: A Further Study of FTC Yield and Nicotine Absorption in Smokers; Psychopharmacology (Berl.) 139 (1998) 291-299.

53. Byrd, G.D., J.H. Robinson, W.S. Caldwell, and J.D. deBethizy: Comparison of Measured and FTC-Predicted Nicotine Uptake in Smokers; Psychopharmacology (Berl.) 122 (1995) 95-103. 
54. Meger, M., I. Meger-Kossien, A. Schuler-Metz, D. Janket, and G. Scherer: Simultaneous Determination of Nicotine and Eight Nicotine Metabolites in Urine of Smokers Using Liquid Chromatography Tandem Mass Spectrometry; J. Chromatogr. B 778 (2002) 251-261.

55. Piller, M., G. Gilch, G. Scherer, and M. Scherer: Simple, Fast and Sensitive LC-MS/MS Analysis for the Simultaneous Quantification of Nicotine and 10 of its Major Metabolites; J. Chromatogr. B 951-952 (2014) 7-15.

56. Jarvis, M., H. Tunstall-Pedoe, C. Feyerabend, C. Vesey, and Y. Salloojee: Biochemical Markers of Smoke Absorption and Self Reported Exposure to Passive Smoking; J. Epidemiol. Community Health 38 (1984) 335-339.

57. Scherer, G., U. Krämer, I. Meger-Kossien, K. Riedel, W.D. Heller, E. Link, J.G. Gostomzyk, J. Ring, and H. Behrendt: Determinants of Children's Exposure to Environmental Tobacco Smoke (ETS): A Study in Southern Germany; J. Expo. Anal. Environ. Epidemiol. 14 (2004) 284-292.

58. Larson, P.S., H.B. Haag, and H. Silvette: Tobacco: Experimental and Clinical Studies, The Williams \& Wilkins Co., Baltimore, USA, 1961.

59. Baumeister, R.G.H., H. Schievelbein, and G. Zickgraf-Rüdel: Toxicological and Clinical Aspects of Cyanide Metabolism; Arzneimittel-Forschung (Drug Research) 25 (1975) 1056-1064.

60. Toraño, J.S. and H.J. van Kan: Simultaneous Determination of the Tobacco Smoke Uptake Parameters Nicotine, Cotinine and Thiocyanate in Urine, Saliva and Hair, Using Gas Chromatography-Mass Spectrometry for Characterisation of Smoking Status of Recently Exposed Subjects; Analyst 128 (2003) 838-843.

61. Degiampietro, P., E. Peheim, D. Drew, H. Graf, and J.P. Colombo: Determination of Thiocyanate in Plasma and Saliva without Deproteinisation and its Validation as a Smoking Parameter; J. Clin. Chem. Clin. Biochem. 25 (1987) 711-717.

62. Junge, B.: Changes in Serum Thiocyanate Concentration on Stopping Smoking; Br. Med. J. 291 (1985) 22.

63. Bliss, R.E. and K.A. O'Connell: Problems with Thiocyanate as an Index of Smoking Status: A Critical Review with Suggestions for Improving the Usefulness of Biochemical Measures in Smoking Cessation Research; Health Psychol. 3 (1984) 563-581.

64. Scherer, G.: Carboxyhemoglobin and Thiocyanate as Biomarkers of Exposure to Carbon Monoxide and Hydrogen Cyanide in Tobacco Smoke; Exp.Toxicol. Pathol. 58 (2006) 101-124.

65. Landaw, S.A., E.W. Callahan Jr, and R. Schmid: Catabolism of Heme In Vivo: Comparison of the Simultaneous Production of Bilirubin and Carbon Monoxide; J. Clin. Invest. 49 (1970) 914-925.

66. Benowitz, N.L.: The Use of Biologic Fluid Samples in Assessing Tobacco Smoke Consumption; in: Measurement in the Analysis and Treatment of Smoking Behavior, edited by J. Grabowski and C.S. Bell, NIDA Research Monograph 48, National Institute on Drug Abuse, Rockville, MD, USA, 1983, pp. 6-26.

67. Cohen, S.I., N.M. Perkins, H.K. Ury, and J.R. Gold- smith: Carbon Monoxide Uptake in Cigarette Smoking; Arch. Environ. Health 22 (1971) 55-60.

68. Heinemann, G., H. Schievelbein, and F. Richter: Die analytische und diagnostische Validität der Bestimmung von Carboxyhämoglobin im Blut und Kohlenmonoxid in der Atemluft von Rauchern und Nichtrauchern [Analytic and Diagnostic Validity of the Determination of Carboxyhemoglobin in Blood and Carbon Monoxide in the Breath of Smokers and Nonsmokers]; J. Clin. Chem. Clin. Biochem. 22 (1984) 229-235.

69. Irving, J.M., E.C. Clark, I.K. Crombie, and W.C.S. Smith: Evaluation of a Portable Measure of ExpiredAir Carbon Monoxide; Prev. Med. 17 (1988) 109-115.

70. Jarvis, M.J., M.A.H. Russell, and Y. Saloojee: Expired Air Carbon Monoxide: A Simple Breath Test of Tobacco Smoke Intake; Br. Med. J. 281 (1980) 484-485.

71. Goniewicz, M.L., C.M. Havel, M.W. Peng, P. Jacob III, D. Dempsey, L. Yu, W. Zielinska-Danch, B. Koszowski, J. Czogala, A. Sobczak, and N.L. Benowitz: Elimination Kinetics of the Tobacco-Specific Biomarker and Lung Carcinogen 4-(Methylnitrosamino)1-(3-pyridyl)-1-butanol; Cancer Epidemiol. Biomarkers Prev. 18 (2009) 3421-3425.

72. Hecht, S.S., S.G. Carmella, M. Chen, J.F. Dor Koch, A.T. Miller, S.E. Murphy, J.A. Jensen, C.L. Zimmerman, and D.K. Hatsukami: Quantitation of Urinary Metabolites of a Tobacco-Specific Lung Carcinogen after Smoking Cessation; Cancer Res. 59 (1999) 590-596.

73. Hecht, S.S.: Human Urinary Carcinogen Metabolites: Biomarkers for Investigating Tobacco and Cancer; Carcinogenesis 23 (2002) 907-922.

74. Kavvadias, D., G. Scherer, F. Cheung, G. Errington, J. Shepperd, and M. McEwan: Determination of Tobacco-Specific $N$-Nitrosamines in Urine of Smokers and Non-Smokers; Biomarkers 14 (2009) 547-553.

75. Kavvadias, D., G. Scherer, M. Urban, F. Cheung, G. Errington, J. Shepperd, and M. McEwan: Simultaneous Determination of Four Tobacco-Specific $N$ Nitrosamines (TSNA) in Human Urine; J. Chromatogr. B 877 (2009) 1185-1192.

76. Stepanov, I. and S.S. Hecht: Tobacco-Specific Nitrosamines and Their Pyridine- $N$-glucuronides in the Urine of Smokers and Smokeless Tobacco Users; Cancer Epidemiol. Biomarkers Prev. 14 (2005) 885-891.

77. Atawodi, S.E., S. Lea, F. Nyberg, A. Mukeria, V. Constantinescu, W. Ahrens, I. Brueske-Hohlfeld, C. Fortes, P. Boffetta, and M.D. Friesen: 4-Hydroxy-1(3-pyridyl)-1-butanone-hemoglobin Adducts as Biomarkers of Exposure to Tobacco Smoke: Validation of a Method to Be Used in Multicenter Studies; Cancer Epidemiol. Biomarkers Prev. 7 (1998) 817-821.

78. Hecht, S.S., S.G. Carmella, P.G. Foiles, S.E. Murphy, and L.A. Peterson: Tobacco-Specific Nitrosamine Adducts: Studies in Laboratory Animals and Humans; Environ. Health Perspect. 99 (1993) 57-63.

79. Hecht, S.S., S.G. Carmella, and S.E. Murphy: Hemoglobin Adducts as Biomarkers of Exposure to and Metabolic Activation of Carcinogenic Tobacco- 
Specific Nitrosamines; Biomed. Environ. Sci. 4 (1991) 93-103.

80. Schlöbe, D., D. Hölzle, D. Hatz, L. von Meyer, A.R. Tricker, and E. Richter: 4-Hydroxy-1-(3-pyridyl)-1butanone-Releasing DNA Adducts in Lung, Lower Esophagus and Cardia of Sudden Death Victims; Toxicology 245 (2008) 154-161.

81. Rodgman, A. and T.A. Perfetti: The Composition of Cigarette Smoke: A Catalogue of the Polycyclic Aromatic Hydrocarbons; Beitr. Tabakforsch. Int. 22 (2006) 13-69.

82. Jongeneelen, F. and R.B.M. Anzion: 1-Hydroxypyrene; in: Analyses of Hazardous Substances in Biological Materials, Vol. 3, edited by J. Angerer and K.H. Schaller, VCH Verlagsgesellschaft mbH, Weinheim, Germany, 1991, pp. 151-169,

83. Hagedorn, H.W., G. Scherer, J. Engl, K. Riedel, F. Cheung, G. Errington, J. Shepperd, and M. McEwan: Urinary Excretion of Phenolic Polycyclic Aromatic Hydrocarbons (OH-PAH) in Nonsmokers and in Smokers of Cigarettes with Different ISO Tar Yields; J. Anal. Toxicol. 33 (2009) 301-309.

84. Ramsauer, B., K. Sterz, H.W. Hagedorn, J. Engl, G. Scherer, M. McEwan, G. Errington, J. Shepperd, and F. Cheung: A Liquid Chromatography/Tandem Mass Spectrometry (LC-MS/MS) Method for the Determination of Phenolic Polycyclic Aromatic Hydrocarbons (OH-PAH) in Urine of Non-Smokers and Smokers; Anal. Bioanal. Chem. 399 (2011) 877-889.

85. St Helen, G., M.L. Goniewicz, D. Dempsey, M. Wilson, P. Jacob III, and N.L. Benowitz: Exposure and Kinetics of Polycyclic Aromatic Hydrocarbons (PAHs) in Cigarette Smokers; Chem. Res. Toxicol. 25 (2012) 952-964.

86. Sobus, J.R., M.D. McClean, R.F. Herrick, S. Waidyanatha, F. Onyemauwa, L.L. Kupper, and S.M. Rappaport: Investigation of PAH Biomarkers in the Urine of Workers Exposed to Hot Asphalt; Ann. Occup. Hyg. 53 (2009) 551-560.

87. Sarkar, M., J. Liu, T. Koval, J. Wang, S. Feng, R. Serafin, Y. Jin, Y. Xie, K. Newland, and H.J. Roethig: Evaluation of Biomarkers of Exposure in Adult Cigarette Smokers Using Marlboro Snus; Nicotine Tob. Res. 12 (2010) 105-116.

88. Lafontaine, M., C. Champmartin, P. Simon, P. Delsaut, and C. Funck-Brentano: 3-Hydroxybenzo[a]pyrene in Urine of Smokers and Non-Smokers; Toxicol. Lett. 162 (2006) 181-185.

89. Hecht, S.S., S.G. Carmella, P.W. Villalta, and J.B. Hochalter: Analysis of Phenanthrene and Benzo $[a]$ pyrene Tetraol Enantiomers in Human Urine: Relevance to the Bay Region Diol Epoxide Hypothesis of Benzo $[a]$ pyrene Carcinogenesis and to Biomarker Studies; Chem. Res. Toxicol. 23 (2010) 900-908.

90. Zhong, Y., S.G. Carmella, J.B. Hochalter, S. Balbo, and S.S. Hecht: Analysis of $r-7, t-8,9, c-10$-Tetrahydroxy-7,8,9,10-tetrahydrobenzo[ $[a]$ pyrene in Human Urine: A Biomarker for Directly Assessing Carcinogenic Polycyclic Aromatic Hydrocarbon Exposure Plus Metabolic Activation; Chem. Res. Toxicol. 24 (2011) 73-80.

91. Hecht, S.S. and J.B. Hochalter: Quantitation of Enan- tiomers of $r$-7,t-8,9,c-10-Tetrahydroxy-7,8,9,10-tetrahydrobenzo $[a]$ pyrene in Human Urine: Evidence Supporting Metabolic Activation of Benzo[a]pyrene Via the Bay Region Diol Epoxide; Mutagenesis 29 (2014) 351-356.

92. Scherer, G., S. Frank, K. Riedel, I. Meger-Kossien, and T. Renner: Biomonitoring of Exposure to Polycyclic Aromatic Hydrocarbons of Nonoccupationally Exposed Persons; Cancer Epidemiol. Biomarkers Prev. 9 (2000) 373-380.

93. van Welie, R.T.H., R.G.J.M. van Dijck, N.P.E. Vermeulen, and N.J. van Sittert: Mercapturic Acids, Protein Adducts, and DNA Adducts as Biomarkers of Electrophilic Chemicals; Crit. Rev. Toxicol. 22 (1992) 271-306.

94. Urban, M., G. Gilch, G. Schepers, E. van Miert, and G. Scherer: Determination of the Major Mercapturic Acids of 1,3-Butadiene in Human and Rat Urine Using Liquid Chromatography-Tandem Mass Spectrometry; J. Chromatogr. B 796 (2003) 131-140.

95. Carmella, S.G., M. Chen, S. Han, A. Briggs, J. Jensen, D.K. Hatsukami, and S.S. Hecht: Effects of Smoking Cessation on Eight Urinary Tobacco Carcinogen and Toxicant Biomarkers; Chem. Res. Toxicol. 22 (2009) 734-741.

96. Scherer, G., T. Renner, and M. Meger: Analysis and Evaluation of trans,trans-Muconic Acid as a Biomarker for Benzene Exposure; J. Chromatogr. B 717 (1998) 179-199.

97. van Doorn, R., R.P. Bos, C.M. Leijdekkers, M.A.P. Wagenaas-Zegers, J.L.G. Theuws, and P.T. Henderson: Thioether Concentration and Mutagenicity of Urine from Cigarette Smokers; Int. Arch. Occup. Environ. Health 43 (1979) 159-166.

98. Heinonen, T., V. Kytöniemi, M. Sorsa, and H. Vainio: Urinary Excretion of Thioethers among Low-Tar and Medium-Tar Cigarette Smokers; Int. Arch. Occup. Environ. Health 52 (1983) 11-16.

99. Scherer, G., D.J. Doolittle, T. Ruppert, I. MegerKossien, K. Riedel, A.R. Tricker, and F. Adlkofer: Urinary Mutagenicity and Thioethers in Nonsmokers: Role of Environmental Tobacco Smoke (ETS) and Diet; Mutat. Res. 368 (1996) 195-204.

100. Adlkofer, F., G. Scherer, C. Maltzan, L. Meyerinck, L. Jarczyk, F. Martin, and G. Grimmer: Dietary Influence on Urinary Excretion of OH-Phenanthrenes, Thioethers and Mutagenicity in Man; in: Complex Mixtures and Cancer Risk, edited by H. Vainio, M. Sorsa, and A.J. McMichael, International Agency for Research on Cancer, Lyon, France, 1990, pp. 415-420.

101. Aringer, L. and V. Lidums: Influence of Diet and Other Factors on Urinary Levels of Thioethers; Int. Arch. Occup. Environ. Health 61 (1988) 123-130.

102. Yamasaki, E. and B.N. Ames: Concentration of Mutagens from Urine by Adsorption with the Nonpolar Resin XAD-2: Cigarette Smokers Have Mutagenic Urine; PNAS 74 (1977) 3555-3559.

103. Kado, N.Y., C. Manson, E. Eisenstadt, and D.P.H. Hsieh: The Kinetics of Mutagen Excretion in the Urine of Cigarette Smokers; Mutat. Res. 157 (1985) 227-233.

104. Kobayashi, H. and H. Hayatsu: A Time-Course Study 
on the Mutagenicity of Smokers' Urine; Jap. J. Cancer Res. (Gann) 75 (1984) 489-493.

105. Benowitz, N.L., P. Jacob III, L.T. Kozlowski, and L. $\mathrm{Yu}$ : Influence of Smoking Fewer Cigarettes on Exposure to Tar, Nicotine, and Carbon Monoxide; New Engl. J. Med. 315 (1986) 1310-1313.

106. Connor, T.H., V.M.S. Ramanujam, J.B. Ward Jr, and M.S. Legator: The Identification and Characterization of a Urinary Mutagen Resulting from Cigarette Smoke; Mutat. Res. 113 (1983) 161-172.

107. Peluso, M., M. Castegnaro, C. Malaveille, M. Friesen, L. Garren, A. Hantefenille, P. Vineis, F. Kadlubar, and H. Bartsch: ${ }^{32} \mathrm{P}-$ Postlabelling Analysis of Urinary Mutagens from Smokers of Black Tobacco Implicates 2-Amino-1-methyl-6-phenylimidazo[4,5-b]pyridine (PhIP) as a Major DNA-Damaging Agent; Carcinogenesis 12 (1991) 713-717.

108. Peluso, M., M. Castegnaro, C. Malaveille, G. Talaska, P. Vineis, F. Kadlubar, and H. Bartsch: ${ }^{32}$ P-Postlabelling Analysis of DNA Adducted with Urinary Mutagens from Smokers of Black Tobacco; Carcinogenesis 11 (1990) 1307-1311.

109. Liu, S., L.T. Taylor, M.F. Borgerding, W.M. Coleman III, and B.R. Bombick: Trace Analysis of Mutagenic Heterocyclic Aromatic Amines in Cigarette Smoke Condensate and its Base Fractions Via Silylation-GCMS; Beitr. Tabakforsch. Int. 25 (2013) 550-562.

110. Peng, L. and R.J. Turesky: Mass Spectrometric Characterization of 2-Amino-1-methyl-6-phenylimidazo[4,5-b]pyridine $\mathrm{N}$-Oxidized Metabolites Bound at $\mathrm{Cys}^{34}$ of Human Serum Albumin; Chem. Res. Toxicol. 24 (2011) 2004-2017.

111. Rappaport, S.M., S. Waidyanatha, K. YeowellO’Connell, N. Rothman, M.T. Smith, L. Zhang, Q. $\mathrm{Qu}, \mathrm{R}$. Shore, G. Li, and S. Yin: Protein Adducts as Biomarkers of Human Benzene Metabolism; Chem. Biol. Interact. 153-154 (2005) 103-109.

112. Sørensen, M., H. Autrup, P. Møller, O. Hertel, S.S. Jensen, P. Vinzents, L.E. Knudsen, and S. Loft: Linking Exposure to Environmental Pollutants with Biological Effects; Mutat. Res. 544 (2003) 255-271.

113. Hatsukami, D.K., N.L. Benowitz, S.I. Rennard, C. Oncken, and S.S. Hecht: Biomarkers to Assess the Utility of Potential Reduced Exposure Tobacco Products; Nicotine Tob. Res. 8 (2006) 600-622.

114. Andersson, G., E.K. Vala, and M. Curvall: The Influence of Cigarette Consumption and Smoking Machine Yields of Tar and Nicotine on the Nicotine Uptake and Oral Mucosal Lesions in Smokers; J. Oral Pathol. Med. 26 (1997) 117-123.

115. Benowitz, N.L., S.M. Hall, R.I. Herning, P. Jacob III, R.T. Jones, and A.L. Osman: Smokers of Low-Yield Cigarettes Do Not Consume Less Nicotine; New Engl. J. Med. 309 (1983) 139-142.

116. Bernert, J.T., R.B. Jain, J.L. Pirkle, L. Wang, B.B. Miller, and E.J. Sampson: Urinary Tobacco-Specific Nitrosamines and 4-Aminobiphenyl Hemoglobin Adducts Measured in Smokers of Either Regular or Light Cigarettes; Nicotine Tob. Res. 7 (2005) 729-738.

117. Bridges, R.B., J.G. Combs, J.W. Humble, J.A. Turbek, S.R. Rehm, and N.J. Haley: Population Characteristics and Cigarette Yield as Determinants of Smoke Exposure; Pharmacol. Biochem. Behav. 37 (1990) 17-28.

118. Coultas, D.B., C.A. Stidley, and J.M. Samet: Cigarette Yields of Tar and Nicotine and Markers of Exposure to Tobacco Smoke; Am. Rev. Respir. Dis. 148 (1993) 435-440.

119. Ebert, R.V., M.E. McNabb, K.T. McCusker, and S.L. Snow: Amount of Nicotine and Carbon Monoxide Inhaled by Smokers of Low-Tar, Low-Nicotine Cigarettes; JAMA 250 (1983) 2840-2842.

120. Feng, S., H.J. Roethig, Q. Liang, R. Kinser, Y. Jin, G. Scherer, M. Urban, J. Engl, and K. Riedel: Evaluation of Urinary 1-Hydroxypyrene, $S$-Phenylmercapturic Acid, trans, trans-Muconic Acid, 3-Methyladenine, 3ethyladenine, 8-Hydroxy-2'-deoxyguanosine and Thioethers as Biomarkers of Exposure to Cigarette Smoke; Biomarkers 11 (2006) 28-52.

121. Folsom, A.R., T.F. Pechacek, R. de Gaudemaris, R.V. Luepker, D.R. Jacobs Jr, and R.F. Gillum: Consumption of 'Low-Yield' Cigarettes: Its Frequency and Relationship to Serum Thiocyanate; Am. J. Public Health 74 (1984) 564-568.

122. Gori, G.B. and C. Lynch: Analytical Cigarette Yields as Predictors of Smoke Bioavailability; Regul. Toxicol. Pharmacol. 5 (1985) 314-326.

123. Hecht, S.S., S.E. Murphy, S.G. Carmella, S. Li, J. Jensen, C. Le, A.M. Joseph, and D.K. Hatsukami: Similar Uptake of Lung Carcinogens by Smokers of Regular, Light, and Ultralight Cigarettes; Cancer Epidemiol. Biomarkers Prev. 14 (2005) 693-698.

124. Hee, J., F. Callais, I. Momas, A.M. Laurent, S. Min, P. Molinier, M. Chastagnier, J.R. Claude, and B. Festy: Smokers' Behaviour and Exposure According to Cigarette Yield and Smoking Experience; Pharmacol. Biochem. Behav. 52 (1995) 195-203.

125. Jaffe, J.H., M. Kanzler, L. Friedman, A.J. Stunkard, and K. Verebey: Carbon Monoxide and Thiocyanate Levels in Low Tar/Nicotine Smokers; Addict. Behav. 6 (1981) 337-343.

126. Jarvis, M.J., R. Boreham, P. Primatesta, C. Feyerabend, and A. Bryant: Nicotine Yield from MachineSmoked Cigarettes and Nicotine Intakes in Smokers: Evidence from a Representative Population Survey; J. Natl. Cancer Inst. 93 (2001) 134-138.

127. Maron, D.J. and S.P. Fortmann: Nicotine Yield and Measures of Cigarette Smoke Exposure in a Large Population: Are Lower-Yield Cigarettes Safer?; Am. J. Public Health 77 (1987) 546-549.

128. Melikian, A.A., M.V. Djordjevic, S. Chen, J. Richie, Jr, and S.D. Stellman: Effect of Delivered Dosage of Cigarette Smoke Toxins on the Levels of Urinary Biomarkers of Exposure; Cancer Epidemiol. Biomarkers Prev. 16 (2007) 1408-1415.

129. Nakazawa, A., M. Shigeta, and K. Ozasa: Smoking Cigarettes of Low Nicotine Yield Does Not Reduce Nicotine Intake as Expected: A Study of Nicotine Dependency in Japanese Males; BMC Public Health 4 (2004) 28.

130. Rickert, W.S. and J.C. Robinson: Estimating the Hazards of Less Hazardous Cigarettes. II. Study of Cigarette Yields of Nicotine, Carbon Monoxide, and Hydrogen Cyanide in Relation to Levels of Cotinine, 
Carboxyhemoglobin, and Thiocynate in Smokers; J. Toxicol. Environ. Health 7 (1981) 391-403.

131. Rosa, M., R. Pacifici, I. Altieri, S. Pichini, G. Ottaviani, and P. Zuccaro: How the Steady-State Cotinine Concentration in Cigarette Smokers Is Directly Related to Nicotine Intake; Clin. Pharmacol. Ther. 52 (1992) 324-329.

132. Russell, M.A.H., M.J. Jarvis, C. Feyerabend, and Y. Saloojee: Reduction of Tar, Nicotine and Carbon Monoxide Intake in Low Tar Smokers; J. Epidemiol. Community Health 40 (1986) 80-85.

133. Ueda, K., I. Kawachi, M. Nakamura, H. Nogami, N. Shirokawa, S. Masui, A. Okayama, and A. Oshima: Cigarette Nicotine Yields and Nicotine Intake among Japanese Male Workers; Tob. Control 11 (2002) 55-60.

134. Woodward, M. and H. Tunstall-Pedoe: Self-Titration of Nicotine: Evidence from the Scottish Heart Health Study; Addiction 88 (1993) 821-830.

135. Joseph, A.M., S.S. Hecht, S.E. Murphy, S.G. Carmella, C.T. Le, Y. Zhang, S. Han, and D.K. Hatsukami: Relationships Between Cigarette Consumption and Biomarkers of Tobacco Toxin Exposure; Cancer Epidemiol. Biomarkers Prev. 14 (2005) 2963-2968.

136. Minet, E., F. Cheung, G. Errington, K. Sterz, and G. Scherer: Urinary Excretion of the Acrylonitrile Metabolite 2-Cyanoethylmercapturic Acid is Correlated with a Variety of Biomarkers of Tobacco Smoke Exposure and Consumption; Biomarkers 16 (2011) 89-96.

137. Roethig, H.J., S. Munjal, S. Feng, Q. Liang, M. Sarkar, R.A. Walk, and P.E. Mendes: Population Estimates for Biomarkers of Exposure to Cigarette Smoke in Adult U.S. Cigarette Smokers; Nicotine Tob. Res. 11 (2009) 1216-1225.

138. Law, M.R., J.K. Morris, H.C. Watt, and N.J. Wald: The Dose-response Relationship Between Cigarette Consumption, Biochemical Markers and Risk of Lung Cancer; Br. J. Cancer 75 (1997) 1690-1693.

139. Binnie, V., S. McHugh, L. MacPherson, B. Borland, K. Moir, and K. Malik: The Validation of Self-Reported Smoking Status by Analysing Cotinine Levels in Stimulated and Unstimulated Saliva, Serum and Urine; Oral Dis. 10 (2004) 287-293.

140. Feyerabend, C., R.M.J. Ings, and M.A.H. Russell: Nicotine Pharmacokinetics and its Application to Intake from Smoking; Br. J. Clin. Pharmacol. 19 (1985) 239-247.

141. Scherer, G., L. Jarczyk, W.D. Heller, A. Biber, G.B. Neurath, and F. Adlkofer: Pharmacokinetics of Nicotine, Cotinine, and 3'-Hydroxycotinine in Cigarette Smokers; Klin. Wochenschr. 66, Suppl. 11 (1988) 5-11.

142. Rosenberg, J., N.L. Benowitz, P. Jacob, and K.M. Wilson: Disposition Kinetics and Effects of Intravenous Nicotine; Clin. Pharmacol. Ther. 28 (1980) 517-522.

143. St Charles, F.K., G.R. Krautter, M. Dixon, and D.C. Mariner: A Comparison of Nicotine Dose Estimates in Smokers Between Filter Analysis, Salivary Cotinine, and Urinary Excretion of Nicotine Metabolites; Psychopharmacology (Berl.) 189 (2006) 345-354.
144. Urban, M., D. Kavvadias, K. Riedel, G. Scherer, and A.R. Tricker: Urinary Mercapturic Acids and a Hemoglobin Adduct for the Dosimetry of Acrylamide Exposure in Smokers and Non-Smokers; Inhal. Toxicol. 18 (2006) 831-839.

145 Jarvis, M.J., H. Tunstall-Pedoe, C. Feyerabend, C. Vesey, and Y. Saloojee: Comparison of Tests Used to Distinguish Smokers from Nonsmokers; Am. J. Public Health 77 (1987) 1435-1438.

146. Benowitz, N.L. and P. Jacob III: trans-3'-Hydroxycotinine: Disposition Kinetics, Effects and Plasma Levels During Cigarette Smoking; Br. J. Clin. Pharmacol. 51 (2001) 53-59.

147. Lowe, F.J., E.O. Gregg, and M. McEwan: Evaluation of Biomarkers of Exposure and Potential Harm in Smokers, Former Smokers and Never-Smokers; Clin. Chem. Lab. Med. 47 (2009) 311-320.

148. Carmella, S.G., S. Akerkar, and S.S. Hecht: Metabolites of the Tobacco-Specific Nitrosamine 4(Methylnitrosamino)-1-(3-Pyridyl)-1-Butanone in Smokers' Urine; Cancer Res. 53 (1993) 721-724.

149. Meger, M., I. Meger-Kossien, K. Riedel, and G. Scherer: Biomonitoring of Environmental Tobacco Smoke (ETS)-Related Exposure to 4-(Methylnitrosamino)-1-(3-pyridyl)-1-butanone (NNK); Biomarkers 5 (2000) 33-45.

150. Serdar, B., S. Waidyanatha, Y. Zheng, and S.M. Rappaport: Simultaneous Determination of Urinary 1and 2-Naphthols, 3- and 9-Phenanthrols, and 1Pyrenol in Coke Oven Workers; Biomarkers 8 (2003) 93-109.

151. Gmeiner, G., P. Gärtner, C. Krassnig, and H. Tausch: Identification of Various Urinary Metabolites of Fluorene Using Derivatization Solid-Phase Microextraction; J. Chromatogr. B 766 (2002) 209-218.

152. Boogaard, P.J. and N.J. van Sittert: Biological Monitoring of Exposure to Benzene: A Comparison Between S-Phenylmercapturic Acid, trans,trans-Muconic Acid, and Phenol; Occup. Environ. Med. 52 (1995) 611-620.

153. Alwis, K.U., B.C. Blount, A.S. Britt, D. Patel, and D.L. Ashley: Simultaneous Analysis of 28 Urinary VOC Metabolites Using Ultra High Performance Liquid Chromatography Coupled with Electrospray Ionization Tandem Mass Spectrometry (UPLCESI/MSMS); Anal. Chim. Acta. 750 (2012) 152-160.

154. Müller, G. and E. Jeske: S-Phenylmercapturic Acid; in: The MAK-Collection: Biomonitoring Methods, edited by DFG, Wiley-VCH Verlag GmbH, Weinheim, Germany, 1998, pp 143-162.

155. Sterz, K., D. Köhler, T. Schettgen, and G. Scherer: Enrichment and Properties of Urinary Pre- $S$ Phenylmercapturic Acid (Pre-SPMA); J. Chromatogr. B 878 (2010) 2502-2505.

156. Carmella, S.G., M. Chen, Y. Zhang, S. Zhang, D.K. Hatsukami, and S.S. Hecht: Quantitation of AcroleinDerived (3-Hydroxypropyl)mercapturic Acid in Human Urine by Liquid Chromatography-Atmospheric Pressure Chemical Ionization Tandem Mass Spectrometry: Effects of Cigarette Smoking; Chem. Res. Toxicol. 20 (2007) 986-990.

157. Mascher, D.G., H.J. Mascher, G. Scherer, and E.R. 
Schmid: High-Performance Liquid ChromatographicTandem Mass Spectrometric Determination of 3-Hydroxypropylmercapturic Acid in Human Urine; J. Chromatogr. B 750 (2001) 163-169.

158. Sterz, K., G. Scherer, J. Krumsiek, F.J. Theis, and J. Ecker: Identification and Quantification of 1-Hydroxybutene-2-yl Mercapturic Acid in Human Urine by UPLC-HILIC-MS/MS as a Novel Biomarker for 1,3-Butadiene Exposure; Chem. Res. Toxicol. 25 (2012) 1565-1567.

159. van Sittert, N.J.: N-2-Cyanoethyl-valin, N-2Hydroxyethyl-valin, $N$-Methyl-valin (Zum Nachweis einer Belastung/Beanspruchung durch Acrylnitril, Ethylenoxid sowie methylierende Substanzen) [Biomonitoring Methods in German language, 1996]; in: The MAK Collection for Occupational Health and Safety, edited by DFG, VCH Verlagsgesellschaft mbH, Weinheim, Germany, 1996, 1-21.
160. Skipper, P.L., M.S. Bryant, S.R. Tannenbaum, and J.D. Groopman: Analytical Methods for Assessing Exposure to 4-Aminobiphenyl Based on Protein Adduct Formation; J. Occup. Med. 28 (1986) 643-646.

Corresponding author:

Gerhard Scherer

ABF Analytisch-Biologisches Forschungslabor GmbH Goethestraße 20

80336 München

Germany

E-Mail: Gerhard.Scherer@abf-lab.com 


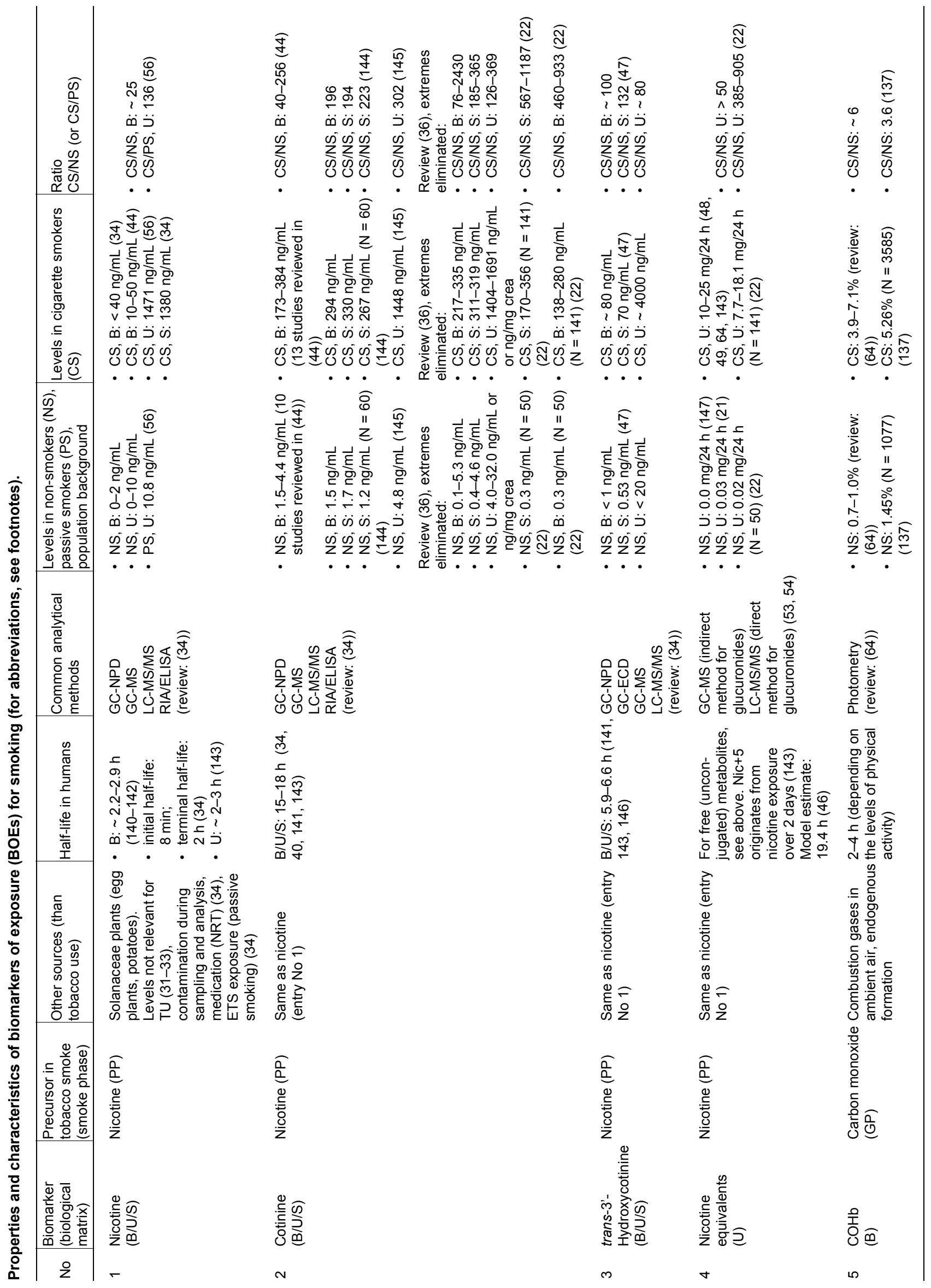




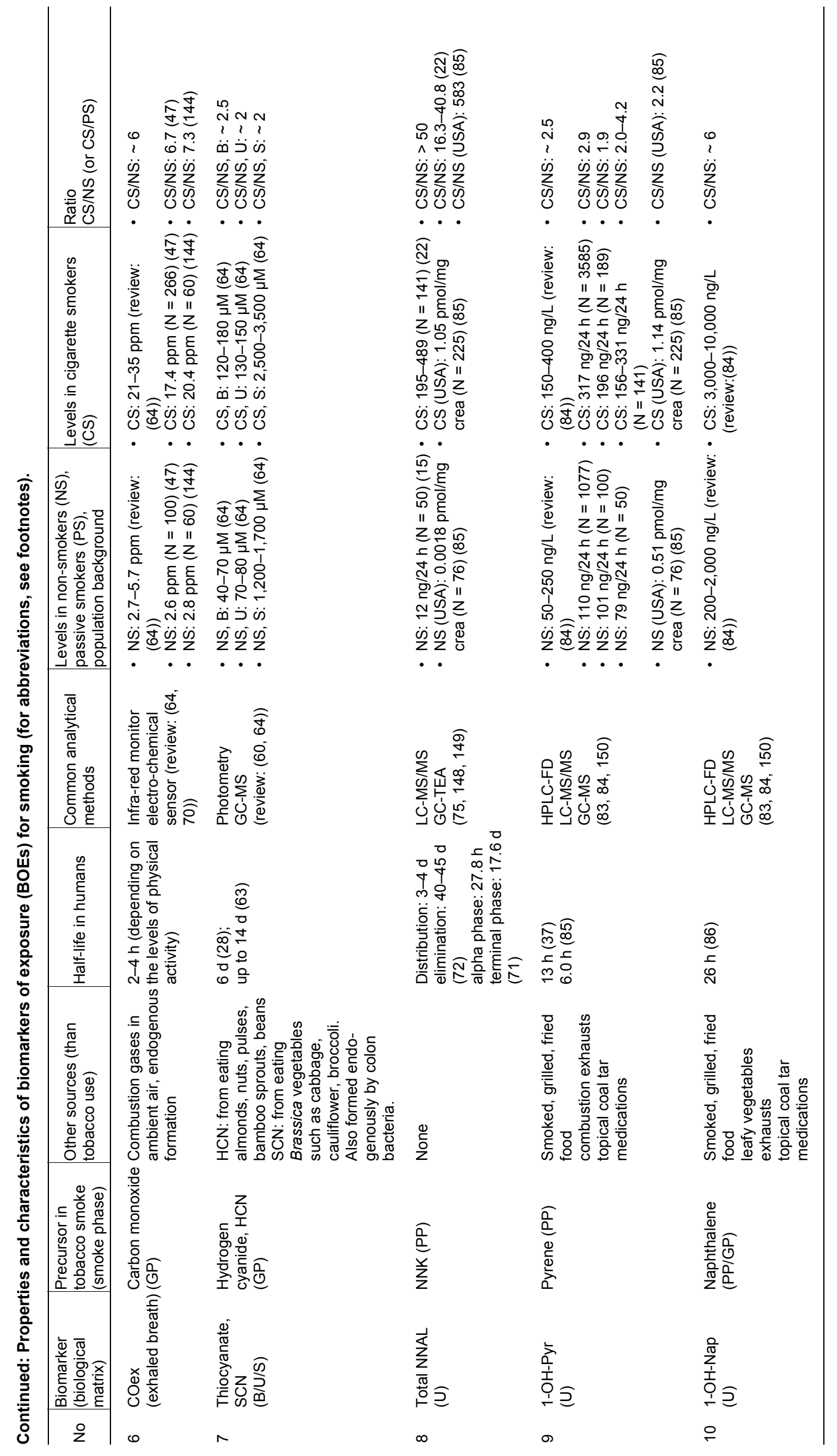




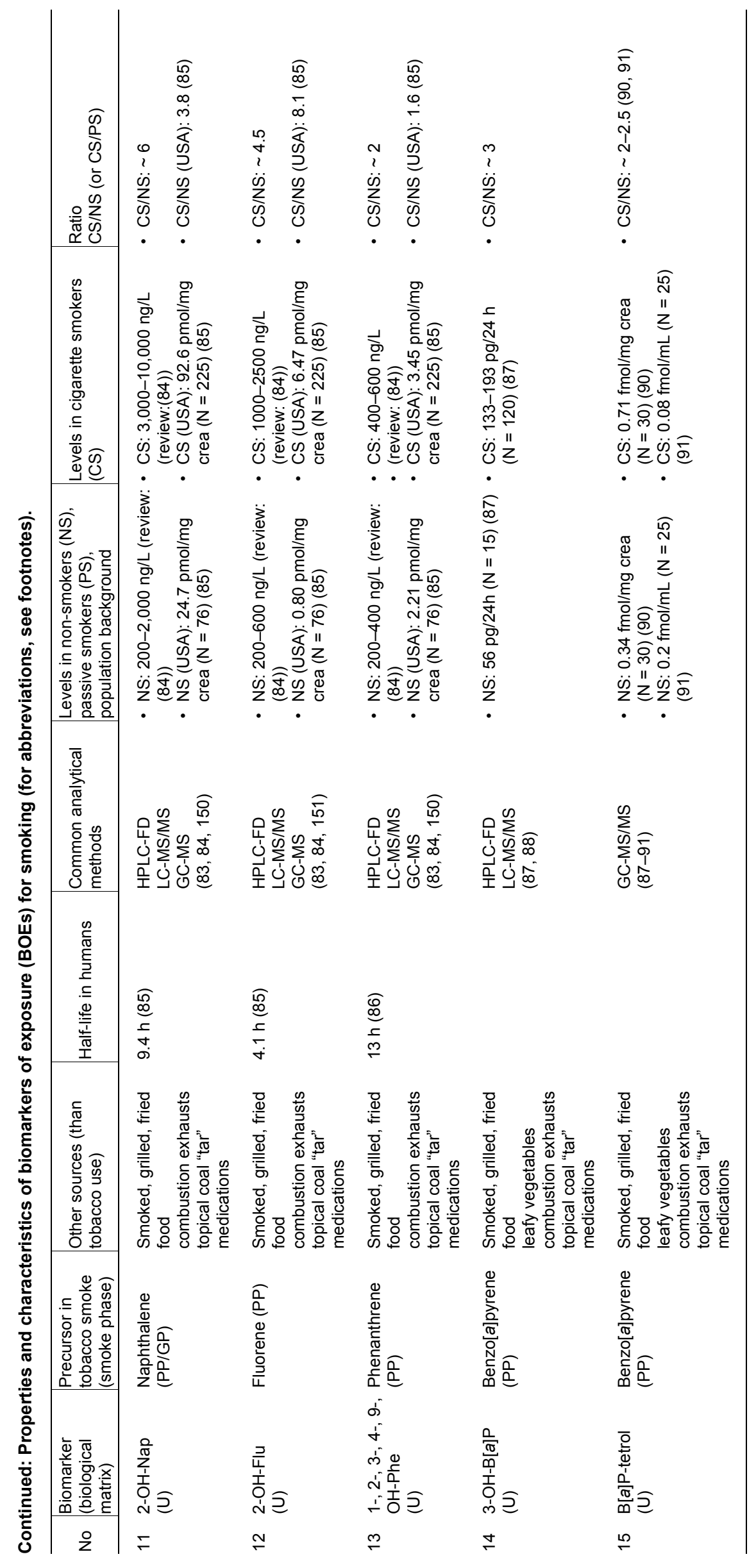




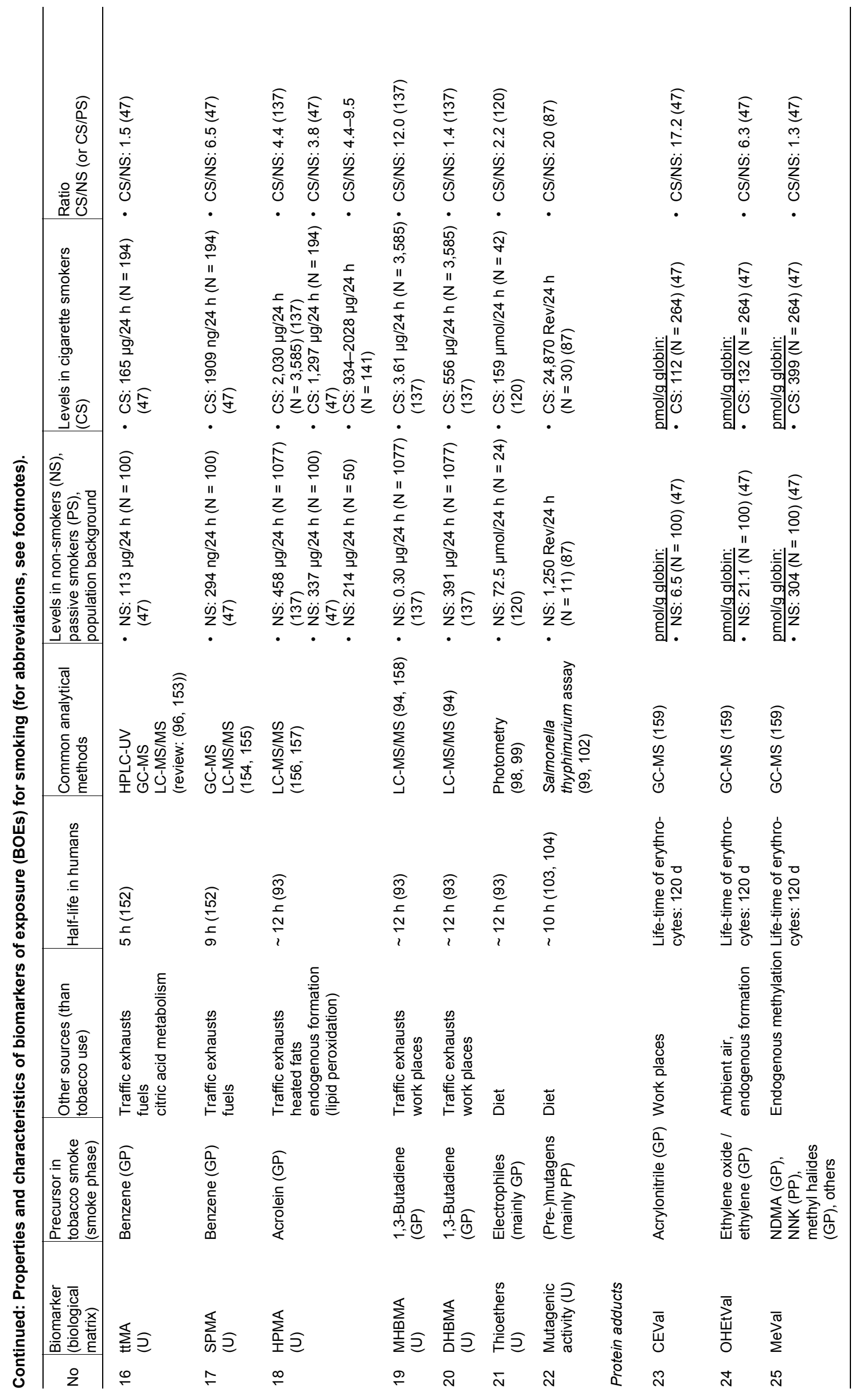




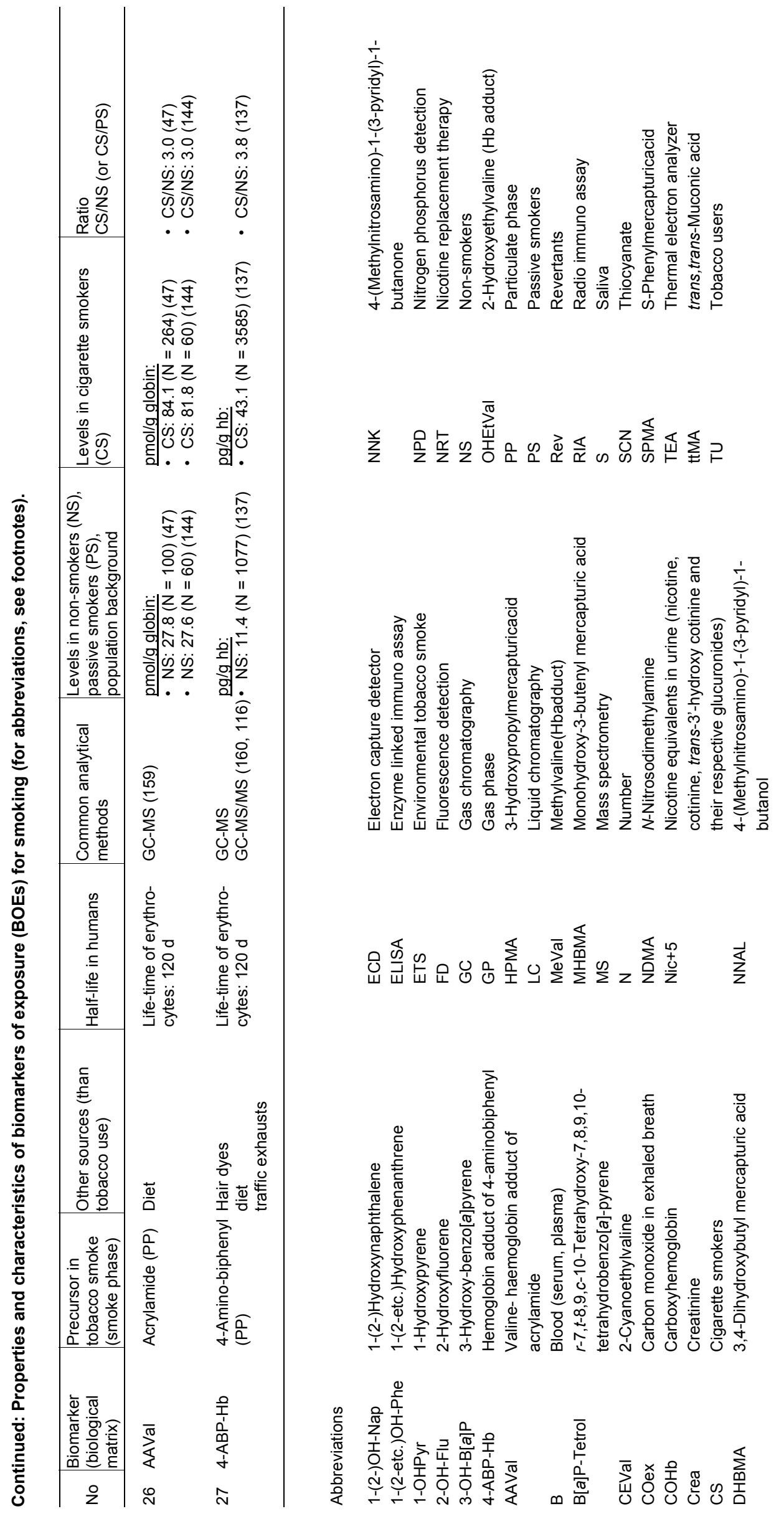




\section{SUPPLEMENTARY DATA 2}

Selected studies with reported data used for the regression analyses. ${ }^{a, b}$

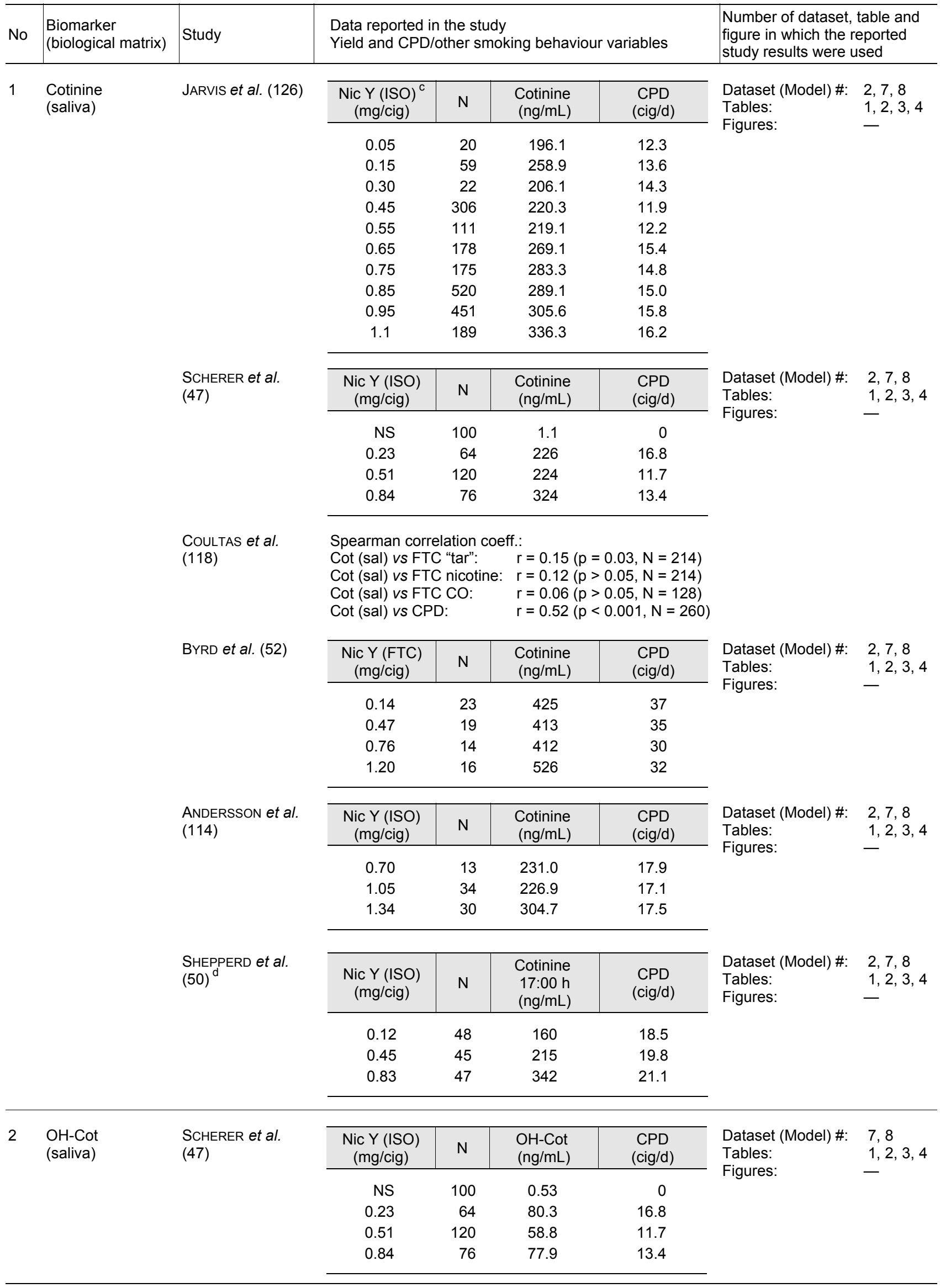


Selected studies with reported data used for the regression analyses. ${ }^{a, b}$ (contd.)

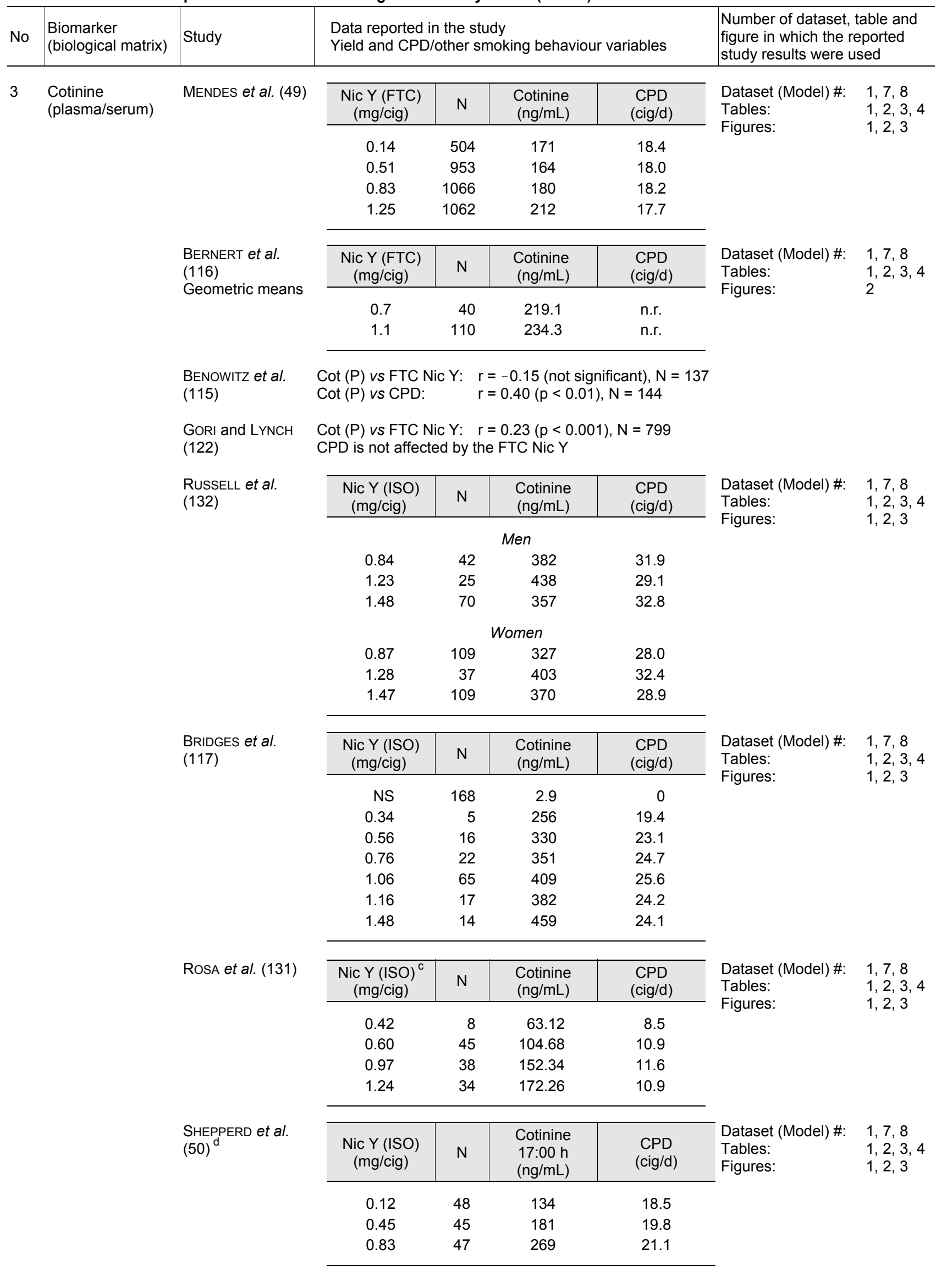


Selected studies with reported data used for the regression analyses. ${ }^{a, b}$ (contd.)

\begin{tabular}{|c|c|c|c|c|c|c|c|c|}
\hline No & $\begin{array}{l}\text { Biomarker } \\
\text { (biological matrix) }\end{array}$ & Study & \multicolumn{4}{|c|}{$\begin{array}{l}\text { Data reported in the study } \\
\text { Yield and CPD/other smoking behaviour variables }\end{array}$} & \multicolumn{2}{|c|}{$\begin{array}{l}\text { Number of dataset, table and } \\
\text { figure in which the reported } \\
\text { study results were used }\end{array}$} \\
\hline \multirow[t]{9}{*}{$\begin{array}{l}3 \\
\text { contd }\end{array}$} & & $\begin{array}{l}\text { WOODWARD and } \\
\text { TUNSTALL-PEDOE }\end{array}$ & $\begin{array}{l}\mathrm{Nic} Y(\text { ISO })^{\mathrm{e}} \\
(\mathrm{mg} / \mathrm{cig})\end{array}$ & $\mathrm{N}$ & $\begin{array}{l}\text { Cotinine } \\
(\mathrm{ng} / \mathrm{mL})\end{array}$ & $\begin{array}{l}\text { CPD } \\
\text { (cig/d) }\end{array}$ & \multirow{9}{*}{$\begin{array}{l}\text { Dataset (Model) \#: } \\
\text { Tables: } \\
\text { Figures: }\end{array}$} & \multirow{9}{*}{$\begin{array}{l}1,7,8 \\
1,2,3,4 \\
1,2,3\end{array}$} \\
\hline & & & \multicolumn{4}{|c|}{ Men } & & \\
\hline & & & 0.80 & 136 & 279.0 & 20.2 & & \\
\hline & & & 1.30 & 315 & 293.6 & 21.4 & & \\
\hline & & & 1.60 & 388 & 281.0 & 20.8 & & \\
\hline & & & \multicolumn{4}{|c|}{ Women } & & \\
\hline & & & 0.80 & 374 & 217 & 15.8 & & \\
\hline & & & 1.30 & 330 & 265.0 & 16.6 & & \\
\hline & & & 1.60 & 449 & 270.4 & 17.9 & & \\
\hline \multirow[t]{4}{*}{4} & $\begin{array}{l}\text { Nicotine } \\
\text { (plasma) }\end{array}$ & EBERT et al. (119) & $\begin{array}{l}\mathrm{Nic} Y(\text { ISO) } \\
(\mathrm{mg} / \mathrm{cig})\end{array}$ & $\mathrm{N}$ & $\begin{array}{l}\text { Nicotine } \\
(\mathrm{ng} / \mathrm{mL})\end{array}$ & $\begin{array}{l}\mathrm{CPD} \\
(\mathrm{cig} / \mathrm{d})\end{array}$ & \multirow{4}{*}{$\begin{array}{l}\text { Dataset (Model) \#: } \\
\text { Tables: } \\
\text { Figures: }\end{array}$} & \multirow{4}{*}{$\begin{array}{l}7,8 \\
1,2,3,4 \\
-\end{array}$} \\
\hline & & & 0.30 & 24 & 24 & 34 & & \\
\hline & & & 0.76 & 23 & 28 & 30 & & \\
\hline & & & 1.20 & 29 & 33 & 30 & & \\
\hline \multirow[t]{23}{*}{5} & \multirow[t]{23}{*}{$\begin{array}{l}\text { Nicotine equiva- } \\
\text { lents } \\
\text { (urine) }\end{array}$} & $\begin{array}{l}\text { SCHERER et al. } \\
(47)\end{array}$ & $\begin{array}{l}\mathrm{Nic} Y(\text { ISO) } \\
(\mathrm{mg} / \mathrm{cig})\end{array}$ & $\mathrm{N}$ & $\begin{array}{c}\mathrm{Nic}+5 \\
(\mathrm{mg} / 24 \mathrm{~h})\end{array}$ & $\begin{array}{l}\mathrm{CPD} \\
\text { (cig/d) }\end{array}$ & \multirow[t]{4}{*}{$\begin{array}{l}\text { Dataset (Model) \#: } \\
\text { Tables: } \\
\text { Figures: }\end{array}$} & \multirow[t]{4}{*}{$\begin{array}{l}3,7,8 \\
1,2,3,4 \\
-\end{array}$} \\
\hline & & & 0.23 & 66 & 12.8 & 16.8 & & \\
\hline & & & 0.51 & 122 & 10.6 & 11.7 & & \\
\hline & & & 0.84 & 78 & 11.5 & 13.4 & & \\
\hline & & \multirow[t]{5}{*}{ MENDES et al. (49) } & $\begin{array}{l}\text { Nic Y (FTC) } \\
(\mathrm{mg} / \mathrm{cig})\end{array}$ & $\mathrm{N}$ & $\begin{array}{c}\mathrm{Nic}+5 \\
(\mathrm{mg} / 24 \mathrm{~h})\end{array}$ & $\begin{array}{l}\text { CPD } \\
\text { (cig/d) }\end{array}$ & \multirow{5}{*}{$\begin{array}{l}\text { Dataset (Model) \#: } \\
\text { Tables: } \\
\text { Figures: }\end{array}$} & \multirow{5}{*}{$\begin{array}{l}3,7,8 \\
1,2,3,4 \\
-\end{array}$} \\
\hline & & & 0.14 & 504 & 11.8 & 18.4 & & \\
\hline & & & 0.51 & 953 & 12.3 & 18.0 & & \\
\hline & & & 0.83 & 1066 & 13.2 & 18.2 & & \\
\hline & & & 1.25 & 1062 & 14.5 & 17.7 & & \\
\hline & & \multirow[t]{5}{*}{ BYRD et al. (53) } & $\begin{array}{l}\text { Nic Y (FTC) } \\
(\mathrm{mg} / \mathrm{cig})\end{array}$ & $\mathrm{N}$ & $\begin{array}{c}\mathrm{Nic}+8 \\
(\mathrm{mg} / 24 \mathrm{~h})\end{array}$ & $\begin{array}{l}\mathrm{CPD} \\
\text { (cig/d) }\end{array}$ & \multirow{5}{*}{$\begin{array}{l}\text { Dataset (Model) \#: } \\
\text { Tables: } \\
\text { Figures: }\end{array}$} & \multirow{5}{*}{$\begin{array}{l}7,8 \\
1,2,3,4 \\
-\end{array}$} \\
\hline & & & 0.14 & 9 & 9.1 & 35 & & \\
\hline & & & 0.49 & 13 & 19.2 & 37 & & \\
\hline & & & 0.67 & 6 & 21.8 & 37 & & \\
\hline & & & 1.13 & 5 & 37.3 & 34 & & \\
\hline & & \multirow[t]{5}{*}{ BYRD et al. (52) } & $\begin{array}{l}\text { Nic Y (FTC) } \\
(\mathrm{mg} / \mathrm{cig})\end{array}$ & $\mathrm{N}$ & $\begin{array}{c}\mathrm{Nic}+8 \\
(\mathrm{mg} / 24 \mathrm{~h})\end{array}$ & $\begin{array}{l}\mathrm{CPD} \\
\text { (cig/d) }\end{array}$ & \multirow{5}{*}{$\begin{array}{l}\text { Dataset (Model) \#: } \\
\text { Tables: } \\
\text { Figures: }\end{array}$} & \multirow{5}{*}{$\begin{array}{l}7,8 \\
1,2,3,4 \\
-\end{array}$} \\
\hline & & & 0.14 & 23 & 22.2 & 37 & & \\
\hline & & & 0.47 & 19 & 21.9 & 35 & & \\
\hline & & & 0.76 & 14 & 20.0 & 30 & & \\
\hline & & & 1.20 & 16 & 27.9 & 32 & & \\
\hline & & \multirow[t]{4}{*}{$\begin{array}{l}\text { ANDERSSON et al. } \\
\text { (114) }\end{array}$} & $\begin{array}{l}\text { Nic Y (ISO) } \\
\text { (mg/cig) }\end{array}$ & $\mathrm{N}$ & $\begin{array}{c}\mathrm{Nic}+7 \\
(\mathrm{mg} / 24 \mathrm{~h})\end{array}$ & $\begin{array}{l}\mathrm{CPD} \\
\text { (cig/d) }\end{array}$ & \multirow{4}{*}{$\begin{array}{l}\text { Dataset (Model) \#: } \\
\text { Tables: } \\
\text { Figures: }\end{array}$} & \multirow[t]{4}{*}{$\begin{array}{l}7,8 \\
1,2,3,4 \\
-\end{array}$} \\
\hline & & & 0.70 & 13 & 24.6 & 17.9 & & \\
\hline & & & 1.05 & 34 & 23.4 & 17.1 & & \\
\hline & & & 1.34 & 30 & 25.7 & 17.5 & & \\
\hline
\end{tabular}


Selected studies with reported data used for the regression analyses. ${ }^{a, b}$ (contd.)

\begin{tabular}{|c|c|c|c|c|c|c|c|c|}
\hline No & $\begin{array}{l}\text { Biomarker } \\
\text { (biological matrix) }\end{array}$ & Study & \multicolumn{4}{|c|}{$\begin{array}{l}\text { Data reported in the study } \\
\text { Yield and CPD/other smoking behaviour variables }\end{array}$} & \multicolumn{2}{|c|}{$\begin{array}{l}\text { Number of dataset, table and } \\
\text { figure in which the reported } \\
\text { study results were used }\end{array}$} \\
\hline \multirow[t]{4}{*}{$\begin{array}{l}5 \\
\text { cont }\end{array}$} & & $\begin{array}{l}\text { SHEPPERD et al. } \\
(50)^{d}\end{array}$ & $\begin{array}{l}\text { Nic } Y(\text { ISO }) \\
(\mathrm{mg} / \mathrm{cig})\end{array}$ & $\mathrm{N}$ & $\begin{array}{c}\mathrm{Nic}+5 \\
(\mathrm{mg} / 24 \mathrm{~h})\end{array}$ & $\begin{array}{l}\text { CPD } \\
(\mathrm{cig} / \mathrm{d})\end{array}$ & \multirow{4}{*}{$\begin{array}{l}\text { Dataset (Model) \#: } \\
\text { Tables: } \\
\text { Figures: }\end{array}$} & $\begin{array}{l}3,7,8 \\
1,2,3,4 \\
-\end{array}$ \\
\hline & & & 0.12 & 48 & 7.1 & 18.5 & & \\
\hline & & & 0.45 & 45 & 12.4 & 19.8 & & \\
\hline & & & 0.83 & 47 & 18.0 & 21.1 & & \\
\hline
\end{tabular}

MUHAMMAD-KAH et The number of cigarettes smoked per day (CPD) is the most important factor in the al. (9) models for daily exposure to nicotine.

Other important smoking-related factors were number of years smoked, smoking behaviour questions from the FTND, topography parameters (i.e., total puff duration and puff count) and "tar" yield categories. When daily exposure to nicotine is adjusted by daily cigarette butts returned (Nic+5 per cig), the most important factors contributing to exposure are the topography parameters (total puff volume, puff count and total inter-puff interval).

"... In conclusion, the models investigated in the study, explain about $30-40 \%$ of variability in daily exposure to nicotine and carbon monoxide. ..."

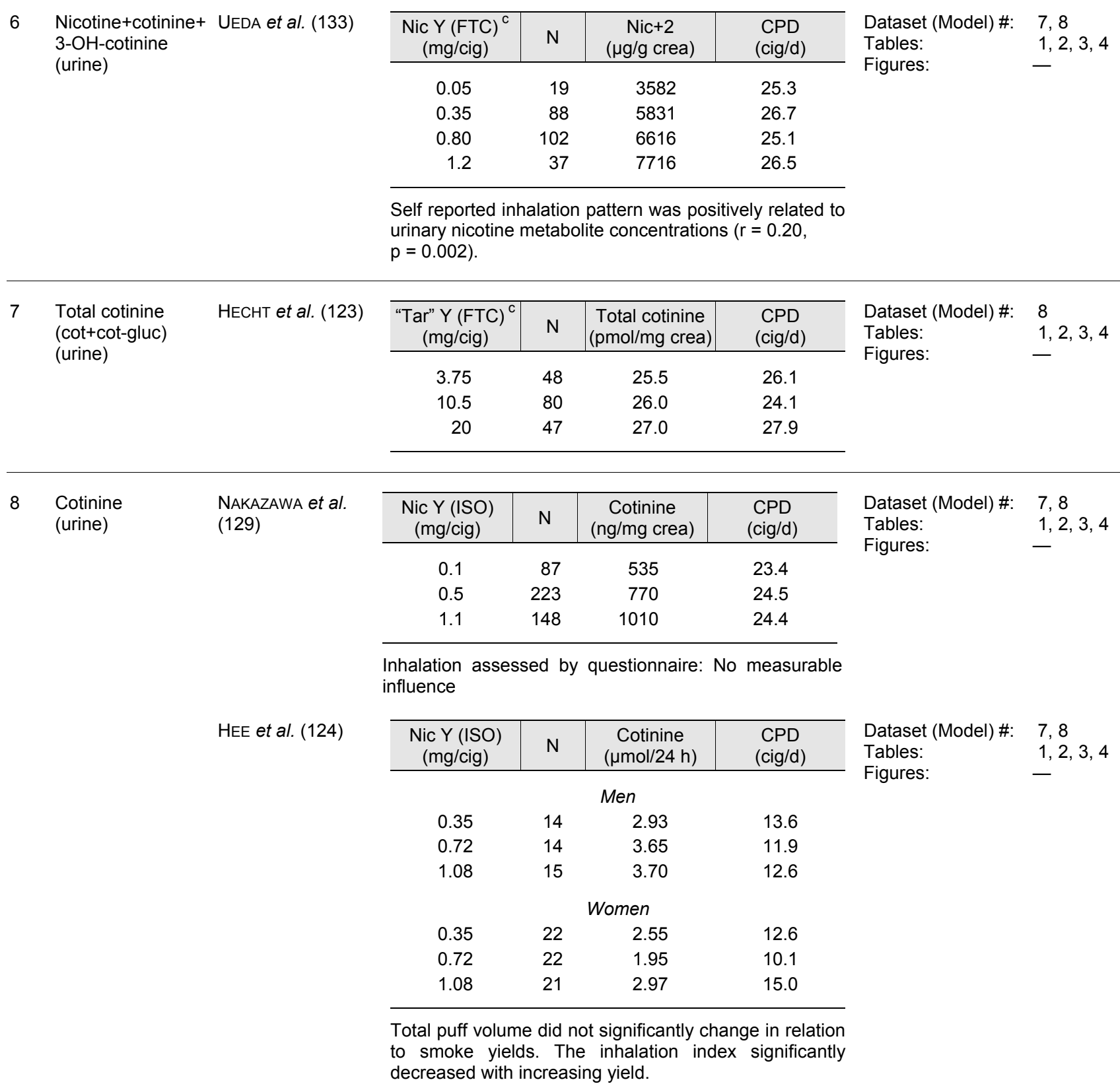


Selected studies with reported data used for the regression analyses. ${ }^{a, b}$ (contd.)

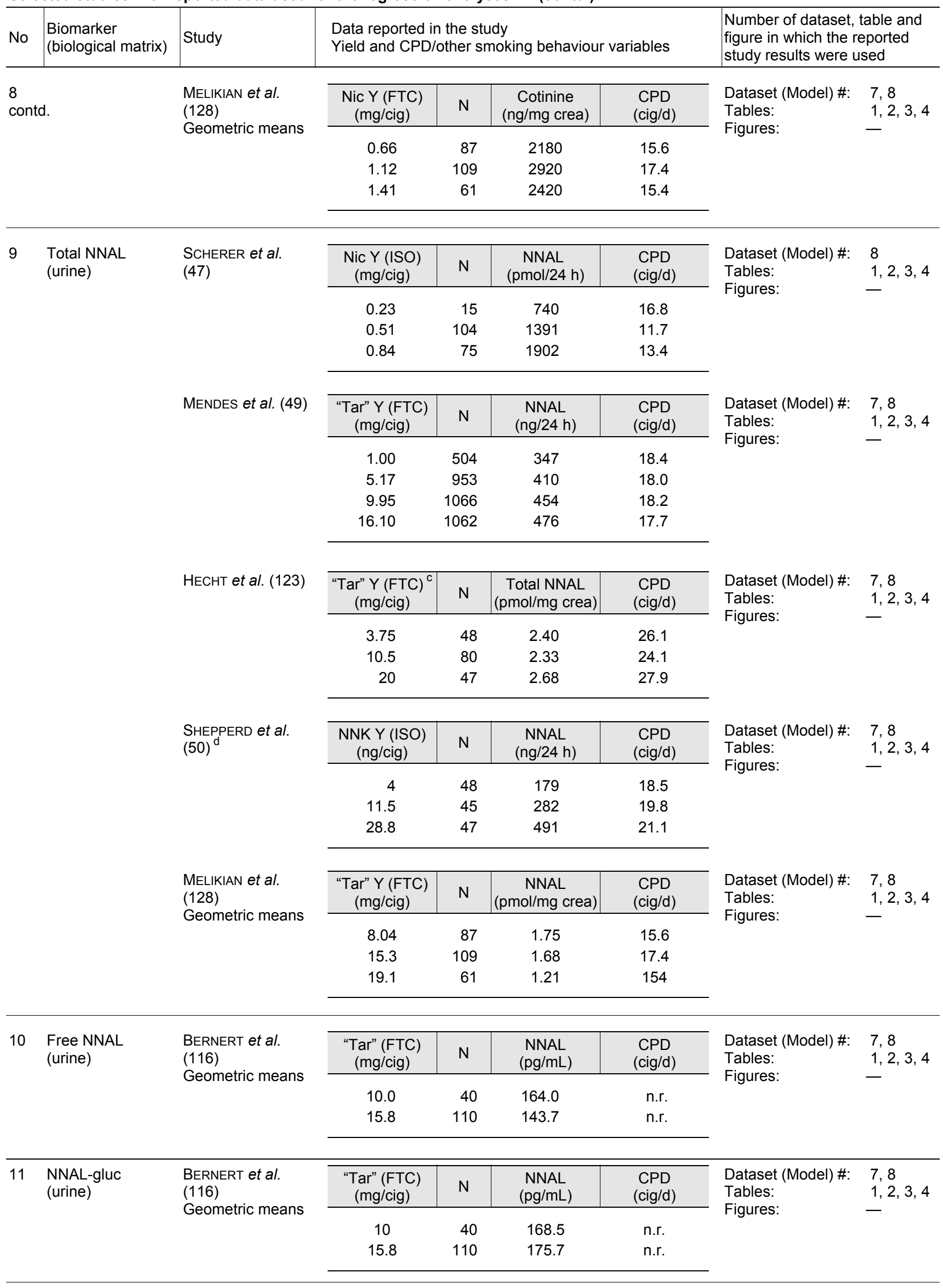


Selected studies with reported data used for the regression analyses. ${ }^{a, b}$ (contd.)

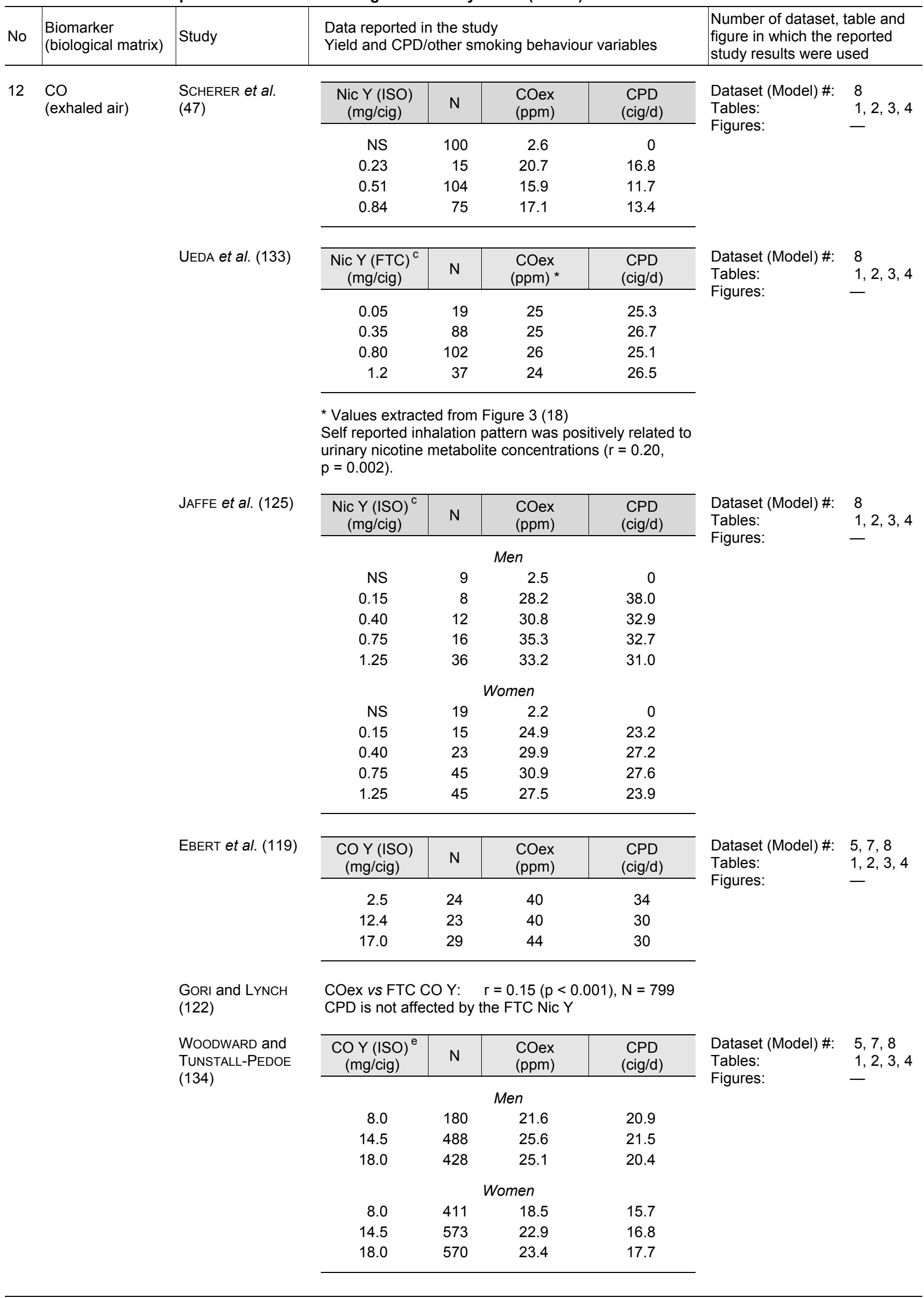


Selected studies with reported data used for the regression analyses. ${ }^{a, b}$ (contd.)

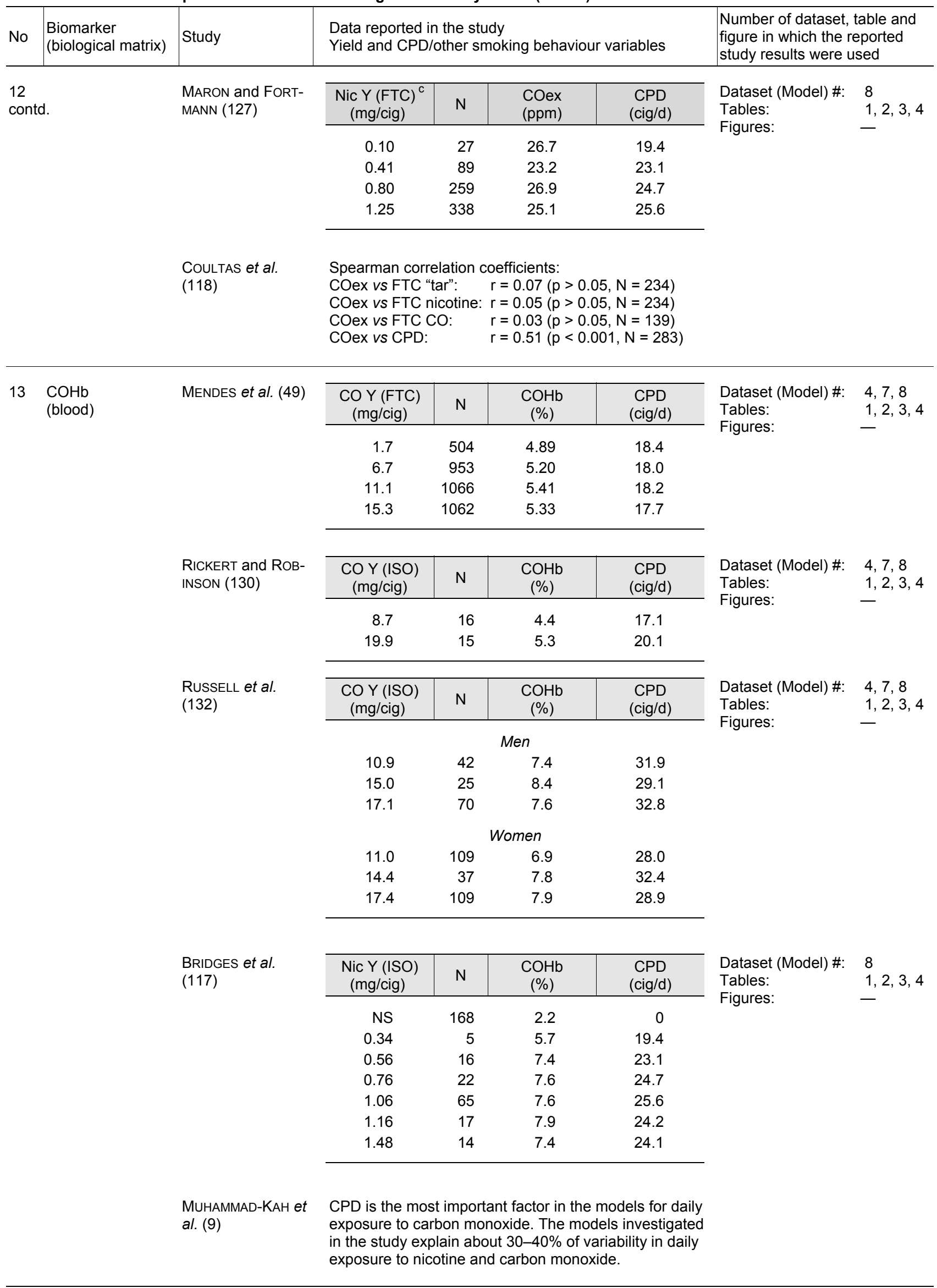


Selected studies with reported data used for the regression analyses. ${ }^{a, b}$ (contd.)

\begin{tabular}{|c|c|c|c|c|c|c|c|c|}
\hline No & $\begin{array}{l}\text { Biomarker } \\
\text { (biological matrix) }\end{array}$ & Study & \multicolumn{4}{|c|}{$\begin{array}{l}\text { Data reported in the study } \\
\text { Yield and CPD/other smoking behaviour variables }\end{array}$} & \multicolumn{2}{|c|}{$\begin{array}{l}\text { Number of dataset, table and } \\
\text { figure in which the reported } \\
\text { study results were used }\end{array}$} \\
\hline \multirow[t]{10}{*}{$\begin{array}{l}13 \\
\text { contc }\end{array}$} & & HEE et al. (124) & $\begin{array}{l}\mathrm{CO} Y(\mathrm{ISO}) \\
(\mathrm{mg} / \mathrm{cig})\end{array}$ & $\mathrm{N}$ & $\mathrm{COHb}(\%)$ & $\begin{array}{l}\text { CPD } \\
\text { (cig/d) }\end{array}$ & \multirow{10}{*}{$\begin{array}{l}\text { Dataset (Model) \#: } \\
\text { Tables: } \\
\text { Figures: }\end{array}$} & \multirow{10}{*}{$\begin{array}{l}4,7,8 \\
1,2,3,4 \\
-\end{array}$} \\
\hline & & & \multicolumn{4}{|c|}{ Men } & & \\
\hline & & & 3.24 & 14 & \multicolumn{2}{|l|}{4.80} & & \\
\hline & & & 9.09 & 14 & \multicolumn{2}{|l|}{5.23} & & \\
\hline & & & 13.60 & 15 & \multicolumn{2}{|l|}{5.74} & & \\
\hline & & & \multicolumn{4}{|c|}{ Women } & & \\
\hline & & & 3.24 & 22 & 4.82 & 12.6 & & \\
\hline & & & 9.09 & 22 & 5.94 & 10.1 & & \\
\hline & & & 13.60 & 21 & 6.73 & 15.0 & & \\
\hline & & & \multicolumn{4}{|c|}{$\begin{array}{l}\text { Total puff volume did not significantly change in relation } \\
\text { to smoke yields. } \\
\text { The inhalation index significantly decreased with in- } \\
\text { creasing yield. }\end{array}$} & & \\
\hline \multirow[t]{23}{*}{14} & \multirow[t]{23}{*}{$\begin{array}{l}\text { 1-OH-Pyr } \\
\text { (urine) }\end{array}$} & \multirow[t]{5}{*}{$\begin{array}{l}\text { SCHERER et al. } \\
(47)\end{array}$} & $\begin{array}{l}\text { Nic } Y(\text { ISO }) \\
(\mathrm{mg} / \mathrm{cig})\end{array}$ & $\mathrm{N}$ & $\begin{array}{l}\text { 1-OH-Pyr } \\
(\mu \mathrm{g} / 24 \mathrm{~h})\end{array}$ & $\begin{array}{l}\text { CPD } \\
\text { (cig/d) }\end{array}$ & \multirow{5}{*}{$\begin{array}{l}\text { Dataset (Model) \#: } \\
\text { Tables: } \\
\text { Figures: }\end{array}$} & \multirow{5}{*}{$\begin{array}{l}8 \\
1,2,3,4 \\
-\end{array}$} \\
\hline & & & NS & 100 & 0.101 & 0 & & \\
\hline & & & 0.23 & 15 & 0.165 & 16.8 & & \\
\hline & & & 0.51 & 101 & 0.194 & 11.7 & & \\
\hline & & & 0.84 & 73 & 0.205 & 13.4 & & \\
\hline & & \multirow[t]{5}{*}{$\begin{array}{l}\text { HAGEDORN et al. } \\
(83) \\
\text { Medians reported }\end{array}$} & $\begin{array}{l}\text { "Tar" Y (ISO) } \\
\text { (mg/cig) }\end{array}$ & $\mathrm{N}$ & $\begin{array}{l}\text { 1-OH-Pyr } \\
(\mu \mathrm{g} / 24 \mathrm{~h})\end{array}$ & $\begin{array}{l}\text { CPD } \\
\text { (cig/d) }\end{array}$ & \multirow[t]{5}{*}{$\begin{array}{l}\text { Dataset (Model) \#: } \\
\text { Tables: } \\
\text { Figures: }\end{array}$} & \multirow[t]{5}{*}{$\begin{array}{l}6,7,8 \\
1,2,3,4 \\
-\end{array}$} \\
\hline & & & NS & 25 & 0.18 & 0 & & \\
\hline & & & 1 & 24 & 0.20 & 21 & & \\
\hline & & & 4 & 33 & 0.32 & 25 & & \\
\hline & & & 10 & 25 & 0.37 & 23 & & \\
\hline & & \multirow[t]{5}{*}{ MENDEs et al. (49) } & $\begin{array}{c}\text { "Tar" Y (FTC) } \\
\text { (mg/cig) }\end{array}$ & $\mathrm{N}$ & $\begin{array}{l}\text { 1-OH-Pyr } \\
\text { (ng/24 h) }\end{array}$ & $\begin{array}{l}\text { CPD } \\
\text { (cig/d) }\end{array}$ & \multirow[t]{5}{*}{$\begin{array}{l}\text { Dataset (Model) \#: } \\
\text { Tables: } \\
\text { Figures: }\end{array}$} & \multirow[t]{5}{*}{$\begin{array}{l}6,7,8 \\
1,2,3,4 \\
-\end{array}$} \\
\hline & & & 1.00 & 504 & 294 & 18.4 & & \\
\hline & & & 5.17 & 953 & 279 & 18.0 & & \\
\hline & & & 9.95 & 1066 & 301 & 18.2 & & \\
\hline & & & 16.10 & 1062 & 356 & 17.7 & & \\
\hline & & \multirow[t]{4}{*}{ HECHT et al. (123) } & $\begin{array}{c}\text { "Tar" Y (FTC) }{ }^{c} \\
\text { (mg/cig) }\end{array}$ & $\mathrm{N}$ & \begin{tabular}{|c|} 
1-OH-Pyr \\
(pmol/mg crea)
\end{tabular} & $\begin{array}{l}\text { CPD } \\
\text { (cig/d) }\end{array}$ & \multirow[t]{4}{*}{$\begin{array}{l}\text { Dataset (Model) \#: } \\
\text { Tables: } \\
\text { Figures: }\end{array}$} & \multirow[t]{4}{*}{$\begin{array}{l}7,8 \\
1,2,3,4 \\
-\end{array}$} \\
\hline & & & 3.75 & 48 & 1.53 & 26.1 & & \\
\hline & & & 10.5 & 80 & 1.47 & 24.1 & & \\
\hline & & & 20 & 47 & 1.73 & 27.9 & & \\
\hline & & \multirow[t]{4}{*}{$\begin{array}{l}\text { MELIKIAN et al. } \\
(128) \\
\text { Geometric means }\end{array}$} & $\begin{array}{c}\text { “Tar" Y (FTC) } \\
\text { (mg/cig) }\end{array}$ & $\mathrm{N}$ & $\begin{array}{c}\text { 1-OH-Pyr } \\
\text { (pg/mg crea) }\end{array}$ & $\begin{array}{l}\text { CPD } \\
\text { (cig/d) }\end{array}$ & \multirow[t]{4}{*}{$\begin{array}{l}\text { Dataset (Model) \#: } \\
\text { Tables: } \\
\text { Figures: }\end{array}$} & \multirow[t]{4}{*}{$\begin{array}{l}7,8 \\
1,2,3,4 \\
-\end{array}$} \\
\hline & & & 8.04 & 87 & 378 & 15.6 & & \\
\hline & & & 15.3 & 109 & 396 & 17.4 & & \\
\hline & & & 19.1 & 61 & 347 & 15.4 & & \\
\hline
\end{tabular}


Selected studies with reported data used for the regression analyses. ${ }^{a, b}$ (contd.)

\begin{tabular}{|c|c|c|c|c|c|c|c|c|}
\hline No & $\begin{array}{l}\text { Biomarker } \\
\text { (biological matrix) }\end{array}$ & Study & \multicolumn{4}{|c|}{$\begin{array}{l}\text { Data reported in the study } \\
\text { Yield and CPD/other smoking behaviour variables }\end{array}$} & \multicolumn{2}{|c|}{$\begin{array}{l}\text { Number of dataset, table and } \\
\text { figure in which the reported } \\
\text { study results were used }\end{array}$} \\
\hline \multirow[t]{8}{*}{$\begin{array}{l}14 \\
\text { cont }\end{array}$} & & $\begin{array}{l}\text { SHEPPERD et al. } \\
(50)^{d}\end{array}$ & $\begin{array}{l}\text { Pyr } Y(\text { ISO) } \\
\text { (ng/cig) }\end{array}$ & $\mathrm{N}$ & $\begin{array}{l}\text { 1-OH-Pyr } \\
\text { (ng/24 h) }\end{array}$ & $\begin{array}{l}\text { CPD } \\
\text { (cig/d) }\end{array}$ & \multirow{4}{*}{$\begin{array}{l}\text { Dataset (Model) \#: } \\
\text { Tables: } \\
\text { Figures: }\end{array}$} & \multirow{4}{*}{$\begin{array}{l}7,8 \\
1,2,3,4 \\
-\end{array}$} \\
\hline & & & 11.2 & 48 & 147 & 18.5 & & \\
\hline & & & 33.0 & 45 & 254 & 19.8 & & \\
\hline & & & 49.4 & 47 & 335 & 21.1 & & \\
\hline & & \multirow[t]{4}{*}{ FENG et al. $(120)^{\mathrm{g}}$} & $\begin{array}{l}\text { "Tar" Y (FTC) } \\
\text { (mg/cig) }\end{array}$ & $\mathrm{N}$ & $\begin{array}{l}\text { 1-OH-Pyr } \\
(\mu \mathrm{g} / 24 \mathrm{~h})\end{array}$ & $\begin{array}{l}\text { CPD } \\
\text { (cig/d) }\end{array}$ & \multirow{4}{*}{$\begin{array}{l}\text { Dataset (Model) \#: } \\
\text { Tables: } \\
\text { Figures: }\end{array}$} & \multirow{4}{*}{$\begin{array}{l}6,7,8 \\
1,2,3,4 \\
-\end{array}$} \\
\hline & & & NS & 24 & 0.04 & 0 & & \\
\hline & & & 3 & 20 & 0.13 & 14.3 & & \\
\hline & & & 11 & 20 & 0.14 & 15.9 & & \\
\hline \multirow[t]{5}{*}{15} & \multirow[t]{5}{*}{$\begin{array}{l}\text { 1-OH-Nap } \\
\text { (urine) }\end{array}$} & \multirow[t]{5}{*}{$\begin{array}{l}\text { HAGEDORN et al. } \\
(83) \\
\text { Medians reported }\end{array}$} & $\begin{array}{l}\text { "Tar" Y (ISO) } \\
\text { (mg/cig) }\end{array}$ & $\mathrm{N}$ & $\begin{array}{l}\text { 1-OH-Nap } \\
(\mu \mathrm{g} / 24 \mathrm{~h})\end{array}$ & $\begin{array}{l}\text { CPD } \\
\text { (cig/d) }\end{array}$ & \multirow[t]{5}{*}{$\begin{array}{l}\text { Dataset (Model) \#: } \\
\text { Tables: } \\
\text { Figures: }\end{array}$} & \multirow[t]{5}{*}{$\begin{array}{l}7,8 \\
1,2,3,4 \\
-\end{array}$} \\
\hline & & & NS & 25 & 2.15 & 0 & & \\
\hline & & & 1 & 24 & 7.99 & 21 & & \\
\hline & & & 4 & 33 & 14.07 & 25 & & \\
\hline & & & 10 & 25 & 18.61 & 23 & & \\
\hline \multirow[t]{5}{*}{16} & \multirow[t]{5}{*}{$\begin{array}{l}\text { 2-OH-Nap } \\
\text { (urine) }\end{array}$} & \multirow[t]{5}{*}{$\begin{array}{l}\text { HAGEDORN et al. } \\
(83) \\
\text { Medians reported }\end{array}$} & $\begin{array}{l}\text { "Tar" Y (ISO) } \\
\text { (mg/cig) }\end{array}$ & $\mathrm{N}$ & $\begin{array}{l}\text { 2-OH-Nap } \\
(\mu g / 24 \mathrm{~h})\end{array}$ & $\begin{array}{l}\text { CPD } \\
\text { (cig/d) }\end{array}$ & \multirow[t]{5}{*}{$\begin{array}{l}\text { Dataset (Model) \#: } \\
\text { Tables: } \\
\text { Figures: }\end{array}$} & \multirow[t]{5}{*}{$\begin{array}{l}7,8 \\
1,2,3,4 \\
-\end{array}$} \\
\hline & & & NS & 25 & 3.22 & 0 & & \\
\hline & & & 1 & 24 & 10.43 & 21 & & \\
\hline & & & 4 & 33 & 16.26 & 25 & & \\
\hline & & & 10 & 25 & 20.56 & 23 & & \\
\hline \multirow[t]{5}{*}{17} & \multirow[t]{5}{*}{$\begin{array}{l}\text { 2-OH-Flu } \\
\text { (urine) }\end{array}$} & \multirow[t]{5}{*}{$\begin{array}{l}\text { HAGEDORN et al. } \\
(83) \\
\text { Medians reported }\end{array}$} & $\begin{array}{c}\text { "Tar" Y (ISO) } \\
\text { (mg/cig) }\end{array}$ & $\mathrm{N}$ & $\begin{array}{l}2-\mathrm{OH}-\mathrm{Flu} \\
(\mu \mathrm{g} / 24 \mathrm{~h})\end{array}$ & $\begin{array}{c}\text { CPD } \\
\text { (cig/d) }\end{array}$ & \multirow[t]{5}{*}{$\begin{array}{l}\text { Dataset (Model) \#: } \\
\text { Tables: } \\
\text { Figures: }\end{array}$} & \multirow[t]{5}{*}{$\begin{array}{l}7,8 \\
1,2,3,4 \\
-\end{array}$} \\
\hline & & & NS & 25 & 0.58 & 0 & & \\
\hline & & & 1 & 24 & 1.04 & 21 & & \\
\hline & & & 4 & 33 & 1.63 & 25 & & \\
\hline & & & 10 & 25 & 1.86 & 23 & & \\
\hline \multirow[t]{5}{*}{18} & \multirow[t]{5}{*}{$\begin{array}{l}\text { 2-/3-OH-Phe } \\
\text { (urine) }\end{array}$} & \multirow[t]{5}{*}{$\begin{array}{l}\text { HAGEDORN et al. } \\
(83) \\
\text { Medians reported }\end{array}$} & $\begin{array}{c}\text { “Tar” Y (ISO) } \\
\text { (mg/cig) }\end{array}$ & $\mathrm{N}$ & $\begin{array}{c}\text { 2-/3-OH-Phe } \\
(\mu \mathrm{g} / 24 \mathrm{~h})\end{array}$ & $\begin{array}{c}\text { CPD } \\
\text { (cig/d) }\end{array}$ & \multirow[t]{5}{*}{$\begin{array}{l}\text { Dataset (Model) \#: } \\
\text { Tables: } \\
\text { Figures: }\end{array}$} & \multirow[t]{5}{*}{$\begin{array}{l}7,8 \\
1,2,3,4 \\
-\end{array}$} \\
\hline & & & NS & 25 & 0.38 & 0 & & \\
\hline & & & 1 & 24 & 0.43 & 21 & & \\
\hline & & & 4 & 33 & 0.64 & 25 & & \\
\hline & & & 10 & 25 & 0.75 & 23 & & \\
\hline 19 & $\begin{array}{l}\text { 1-/9-OH-Phe } \\
\text { (urine) }\end{array}$ & $\begin{array}{l}\text { HAGEDORN et al. } \\
\text { (83) } \\
\text { Medians reported }\end{array}$ & $\begin{array}{c}\text { "Tar" Y (ISO) } \\
\text { (mg/cig) }\end{array}$ & $\mathrm{N}$ & $\begin{array}{c}\text { 1-/9-OH-Phe } \\
(\mu \mathrm{g} / 24 \mathrm{~h})\end{array}$ & $\begin{array}{c}\text { CPD } \\
\text { (cig/d) }\end{array}$ & $\begin{array}{l}\text { Dataset (Model) \#: } \\
\text { Tables: } \\
\text { Figures: }\end{array}$ & $\begin{array}{l}7,8 \\
1,2,3,4 \\
-\end{array}$ \\
\hline & & & NS & 25 & 0.28 & 0 & & \\
\hline & & & 1 & 24 & 0.37 & 21 & & \\
\hline & & & 4 & 33 & 0.58 & 25 & & \\
\hline & & & 10 & 25 & 0.67 & 23 & & \\
\hline
\end{tabular}


Selected studies with reported data used for the regression analyses. ${ }^{a, b}$ (contd.)

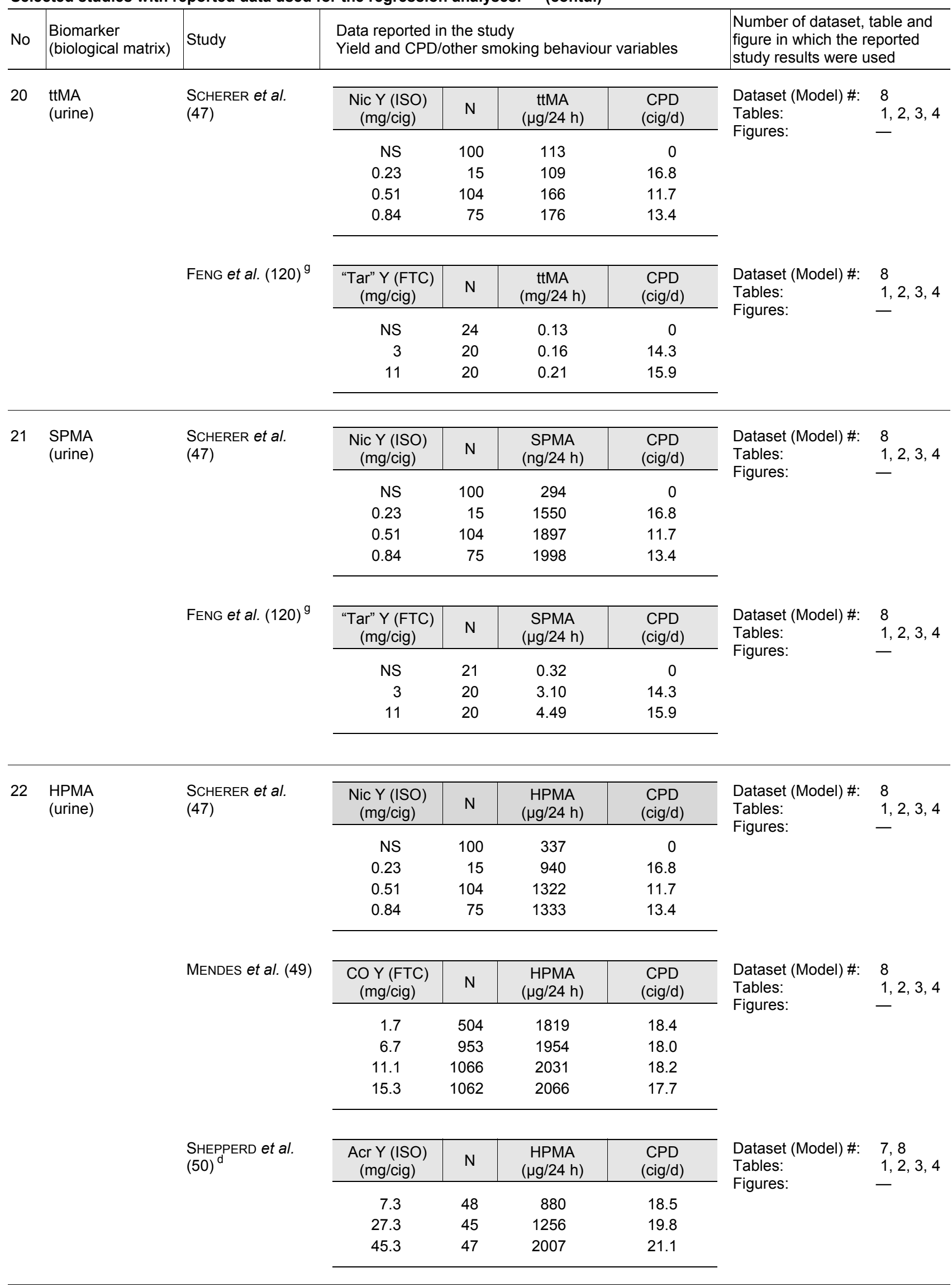


Selected studies with reported data used for the regression analyses. ${ }^{a, b}$ (contd.)

\begin{tabular}{|c|c|c|c|c|c|c|c|c|}
\hline No & $\begin{array}{l}\text { Biomarker } \\
\text { (biological matrix) }\end{array}$ & Study & \multicolumn{4}{|c|}{$\begin{array}{l}\text { Data reported in the study } \\
\text { Yield and CPD/other smoking behaviour variables }\end{array}$} & \multicolumn{2}{|c|}{$\begin{array}{l}\text { Number of dataset, table and } \\
\text { figure in which the reported } \\
\text { study results were used }\end{array}$} \\
\hline \multirow[t]{5}{*}{23} & $\begin{array}{l}\text { MHBMA } \\
\text { (urine) }\end{array}$ & MENDES et al. (49) & $\begin{array}{l}\mathrm{CO} \text { Y (FTC) } \\
(\mathrm{mg} / \mathrm{cig})\end{array}$ & $\mathrm{N}$ & $\begin{array}{l}\text { MHBMA } \\
(\mu g / 24 \mathrm{~h})\end{array}$ & $\begin{array}{l}\text { CPD } \\
\text { (cig/d) }\end{array}$ & \multirow{5}{*}{$\begin{array}{l}\text { Dataset (Model) \#: } \\
\text { Tables: } \\
\text { Figures: }\end{array}$} & \multirow{5}{*}{$\begin{array}{l}8 \\
1,2,3,4 \\
-\end{array}$} \\
\hline & & & 1.7 & 504 & 3.58 & 18.4 & & \\
\hline & & & 6.7 & 953 & 3.52 & 18.0 & & \\
\hline & & & 11.1 & 1066 & 3.58 & 18.2 & & \\
\hline & & & 15.3 & 1062 & 3.46 & 17.7 & & \\
\hline \multirow[t]{5}{*}{24} & $\begin{array}{l}\text { DHBMA } \\
\text { (urine) }\end{array}$ & MENDEs et al. (49) & $\begin{array}{l}\mathrm{CO} Y(\mathrm{FTC}) \\
(\mathrm{mg} / \mathrm{cig})\end{array}$ & $\mathrm{N}$ & $\begin{array}{l}\text { DHBMA } \\
(\mu \mathrm{g} / 24 \mathrm{~h})\end{array}$ & $\begin{array}{l}\text { CPD } \\
\text { (cig/d) }\end{array}$ & \multirow[t]{5}{*}{$\begin{array}{l}\text { Dataset (Model) \#: } \\
\text { Tables: } \\
\text { Figures: }\end{array}$} & \multirow[t]{5}{*}{$\begin{array}{l}8 \\
1,2,3,4 \\
-\end{array}$} \\
\hline & & & 1.7 & 504 & 516 & 18.4 & & \\
\hline & & & 6.7 & 953 & 548 & 18.0 & & \\
\hline & & & 11.1 & 1066 & 541 & 18.2 & & \\
\hline & & & 15.3 & 1062 & 560 & 17.7 & & \\
\hline \multirow[t]{13}{*}{25} & \multirow[t]{13}{*}{$\begin{array}{l}\text { Thiocyanate (sa- } \\
\text { liva) }\end{array}$} & \multirow[t]{7}{*}{ JAFFE et al. (125) } & $\begin{array}{l}\text { Nic Y (ISO) }{ }^{\mathrm{C}} \\
(\mathrm{mg} / \mathrm{cig})\end{array}$ & $\mathrm{N}$ & $\begin{array}{c}\mathrm{SCN} \\
(\mu \mathrm{g} / \mathrm{mL})\end{array}$ & $\begin{array}{l}\text { CPD } \\
\text { (cig/d) }\end{array}$ & \multirow{13}{*}{$\begin{array}{l}\text { Dataset (Model) \#: } \\
\text { Tables: } \\
\text { Figures: }\end{array}$} & $\begin{array}{l}8 \\
1,2,3,4 \\
-\end{array}$ \\
\hline & & & \multicolumn{4}{|c|}{ Men } & & \\
\hline & & & NS & 19 & 75 & 0 & & \\
\hline & & & 0.15 & 6 & 201 & 32.3 & & \\
\hline & & & 0.40 & 7 & 161 & 32.9 & & \\
\hline & & & 0.75 & 11 & 143 & 35.3 & & \\
\hline & & & 1.25 & 27 & 168 & 33.1 & & \\
\hline & & & \multicolumn{4}{|c|}{ Women } & & \\
\hline & & & NS & 33 & 67 & 0 & & \\
\hline & & & 0.15 & 12 & 154 & 17.2 & & \\
\hline & & & 0.40 & 18 & 194 & 27.6 & & \\
\hline & & & 0.75 & 32 & 173 & 28.7 & & \\
\hline & & & 1.25 & 37 & 159 & 24.2 & & \\
\hline \multirow[t]{16}{*}{26} & \multirow[t]{16}{*}{$\begin{array}{l}\text { Thiocyanate } \\
\text { (plasma/serum) }\end{array}$} & $\begin{array}{l}\text { RICKERT and ROB- } \\
\text { INSON (130) }\end{array}$ & $\begin{array}{l}\mathrm{HCN} Y(\text { ISO }) \\
(\mu \mathrm{g} / \mathrm{cig})\end{array}$ & $\mathrm{N}$ & $\begin{array}{c}\text { SCN }(P) \\
(\mu \mathrm{M})\end{array}$ & $\begin{array}{l}\text { CPD } \\
\text { (cig/d) }\end{array}$ & \multirow{3}{*}{$\begin{array}{l}\text { Dataset (Model) \#: } \\
\text { Tables: } \\
\text { Figures: }\end{array}$} & \multirow{3}{*}{$\begin{array}{l}7,8 \\
1,2,3,4 \\
-\end{array}$} \\
\hline & & & 73 & 16 & 71 & 17.1 & & \\
\hline & & & 274 & 15 & 85 & 20.1 & & \\
\hline & & \multirow[t]{8}{*}{$\begin{array}{l}\text { BRIDGES et al. } \\
(117)\end{array}$} & $\begin{array}{l}\text { Nic } \mathrm{Y}(\mathrm{ISO}) \\
(\mathrm{mg} / \mathrm{cig})\end{array}$ & $\mathrm{N}$ & $\begin{array}{l}\text { SCN } \\
(\mu \mathrm{M})\end{array}$ & $\begin{array}{c}\text { CPD } \\
\text { (cig/d) }\end{array}$ & \multirow{8}{*}{$\begin{array}{l}\text { Dataset (Model) \#: } \\
\text { Tables: } \\
\text { Figures: }\end{array}$} & $\begin{array}{l}8 \\
1,2,3,4 \\
-\end{array}$ \\
\hline & & & NS & 168 & 98.3 & 0 & & \multirow{12}{*}{$\begin{array}{l}8 \\
1,2,3,4 \\
-\end{array}$} \\
\hline & & & 0.34 & 5 & 132.2 & 19.4 & & \\
\hline & & & 0.56 & 16 & 160.7 & 23.1 & & \\
\hline & & & 0.76 & 22 & 175.9 & 24.7 & & \\
\hline & & & 1.06 & 65 & 163.6 & 25.6 & & \\
\hline & & & 1.16 & 17 & 143.8 & 24.2 & & \\
\hline & & & 1.48 & 14 & 162.3 & 24.1 & & \\
\hline & & \multirow[t]{5}{*}{$\begin{array}{l}\text { MARON and FORT- } \\
\text { MANN (127) }\end{array}$} & $\begin{array}{l}\text { Nic Y (FTC) })^{\mathrm{C}} \\
(\mathrm{mg} / \mathrm{cig})\end{array}$ & $\mathrm{N}$ & $\begin{array}{l}\text { SCN } \\
(\mu \mathrm{M})\end{array}$ & $\begin{array}{l}\text { CPD } \\
\text { (cig/d) }\end{array}$ & \multirow{5}{*}{$\begin{array}{l}\text { Dataset (Model) \#: } \\
\text { Tables: } \\
\text { Figures: }\end{array}$} & \\
\hline & & & 0.10 & 27 & 144.4 & 19.4 & & \\
\hline & & & 0.41 & 89 & 151.4 & 23.1 & & \\
\hline & & & 0,80 & 259 & 159.3 & 24.7 & & \\
\hline & & & 1.25 & 338 & 156.0 & 25.6 & & \\
\hline
\end{tabular}


Selected studies with reported data used for the regression analyses. ${ }^{a, b}$ (contd.)

\begin{tabular}{|c|c|c|c|c|c|c|c|c|}
\hline No & $\begin{array}{l}\text { Biomarker } \\
\text { (biological matrix) }\end{array}$ & Study & \multicolumn{4}{|c|}{$\begin{array}{l}\text { Data reported in the study } \\
\text { Yield and CPD/other smoking behaviour variables }\end{array}$} & \multicolumn{2}{|c|}{$\begin{array}{l}\text { Number of dataset, table and } \\
\text { figure in which the reported } \\
\text { study results were used }\end{array}$} \\
\hline \multirow[t]{10}{*}{$\begin{array}{l}26 \\
\text { contd }\end{array}$} & & $\begin{array}{l}\text { FoLsom et al. } \\
(121)\end{array}$ & $\begin{array}{l}\text { Partial correlati } \\
\text { SCN vs "tar" Y } \\
\text { SCN vs nicotin } \\
\text { SCN vs CO Y ( }\end{array}$ & $\begin{array}{l}\text { n coef } \\
\text { =TC): } \\
\text { Y (FT } \\
\text { TC): }\end{array}$ & 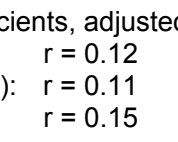 & CPD: & & \\
\hline & & \multirow[t]{9}{*}{$\begin{array}{l}\text { WOODWARD and } \\
\text { TUNSTALL-PEDOE } \\
(134)\end{array}$} & $\begin{array}{c}\mathrm{COY}(\mathrm{ISO})^{\mathrm{e}} \\
(\mathrm{mg} / \mathrm{cig})\end{array}$ & $\mathrm{N}$ & $\begin{array}{l}\text { SCN } \\
(\mu \mathrm{M})\end{array}$ & $\begin{array}{l}\text { CPD } \\
\text { (cig/d) }\end{array}$ & \multirow[t]{9}{*}{$\begin{array}{l}\text { Dataset (Model) \#: } \\
\text { Tables: } \\
\text { Figures: }\end{array}$} & \multirow[t]{9}{*}{$\begin{array}{l}8 \\
1,2,3,4 \\
-\end{array}$} \\
\hline & & & \multicolumn{4}{|c|}{ Men } & & \\
\hline & & & 8.0 & 180 & 114.3 & 20.9 & & \\
\hline & & & 14.5 & 488 & 115.9 & 21.5 & & \\
\hline & & & 18.0 & 428 & 123.9 & 20.4 & & \\
\hline & & & \multicolumn{4}{|c|}{ Women } & & \\
\hline & & & 8.0 & 411 & 121.3 & 15.7 & & \\
\hline & & & 14.5 & 573 & 132.8 & 16.8 & & \\
\hline & & & 18.0 & 570 & 139.8 & 17.7 & & \\
\hline \multirow[t]{5}{*}{27} & $\begin{array}{l}\text { CEVal-Hb } \\
\text { (blood) }\end{array}$ & $\begin{array}{l}\text { SCHERER et al. } \\
(47)\end{array}$ & $\begin{array}{l}\text { Nic Y (ISO) } \\
(\mathrm{mg} / \mathrm{cig})\end{array}$ & $\mathrm{N}$ & $\begin{array}{l}\text { CEVal-Hb } \\
(\mathrm{pmol} / \mathrm{g})\end{array}$ & $\begin{array}{l}\mathrm{CPD} \\
(\mathrm{cig} / \mathrm{d})\end{array}$ & \multirow[t]{5}{*}{$\begin{array}{l}\text { Dataset (Model) \#: } \\
\text { Tables: } \\
\text { Figures: }\end{array}$} & \multirow[t]{5}{*}{$\begin{array}{l}8 \\
1,2,3,4 \\
-\end{array}$} \\
\hline & & & NS & 100 & 6.5 & 0 & & \\
\hline & & & 0.23 & 65 & 143 & 16.8 & & \\
\hline & & & 0.51 & 121 & 94 & 11.7 & & \\
\hline & & & 0.84 & 78 & 115 & 13.4 & & \\
\hline \multirow[t]{5}{*}{28} & $\begin{array}{l}\text { OHEtVal-Hb } \\
\text { (blood) }\end{array}$ & $\begin{array}{l}\text { SCHERER et al. } \\
(47)\end{array}$ & $\begin{array}{l}\text { Nic Y (ISO) } \\
(\mathrm{mg} / \mathrm{cig})\end{array}$ & $\mathrm{N}$ & $\begin{array}{c}\text { OHEtVal-Hb } \\
(\mathrm{pmol} / \mathrm{g})\end{array}$ & $\begin{array}{l}\text { CPD } \\
(\mathrm{cig} / \mathrm{d})\end{array}$ & \multirow[t]{5}{*}{$\begin{array}{l}\text { Dataset (Model) \#: } \\
\text { Tables: } \\
\text { Figures: }\end{array}$} & \multirow[t]{5}{*}{$\begin{array}{l}8 \\
1,2,3, \\
-\end{array}$} \\
\hline & & & NS & 100 & 21.1 & 0 & & \\
\hline & & & 0.23 & 65 & 139 & 16.8 & & \\
\hline & & & 0.51 & 121 & 119 & 11.7 & & \\
\hline & & & 0.84 & 78 & 148 & 13.4 & & \\
\hline \multirow[t]{5}{*}{29} & $\begin{array}{l}\text { MeVal-Hb } \\
\text { (blood) }\end{array}$ & $\begin{array}{l}\text { SCHERER et al. } \\
(47)\end{array}$ & $\begin{array}{l}\text { Nic Y (ISO) } \\
(\mathrm{mg} / \mathrm{cig})\end{array}$ & $\mathrm{N}$ & $\begin{array}{c}\mathrm{MeVal-Hb} \\
(\mathrm{pmol} / \mathrm{g})\end{array}$ & $\begin{array}{l}\text { CPD } \\
\text { (cig/d) }\end{array}$ & \multirow[t]{5}{*}{$\begin{array}{l}\text { Dataset (Model) \#: } \\
\text { Tables: } \\
\text { Figures: }\end{array}$} & \multirow[t]{5}{*}{$\begin{array}{l}8 \\
1,2,3, \\
-\end{array}$} \\
\hline & & & NS & 100 & 304 & 0 & & \\
\hline & & & 0.23 & 65 & 392 & 16.8 & & \\
\hline & & & 0.51 & 121 & 390 & 11.7 & & \\
\hline & & & 0.84 & 78 & 418 & 13.4 & & \\
\hline \multirow[t]{5}{*}{30} & $\begin{array}{l}\text { AAVal-Hb } \\
\text { (blood) }\end{array}$ & $\begin{array}{l}\text { SCHERER et al. } \\
(47)\end{array}$ & $\begin{array}{l}\text { Nic Y (ISO) } \\
(\mathrm{mg} / \mathrm{cig})\end{array}$ & $\mathrm{N}$ & $\begin{array}{l}\text { AAVal-Hb } \\
\text { (pmol/g) }\end{array}$ & $\begin{array}{l}\text { CPD } \\
(\mathrm{cig} / \mathrm{d})\end{array}$ & \multirow{5}{*}{$\begin{array}{l}\text { Dataset (Model) \#: } \\
\text { Tables: } \\
\text { Figures: }\end{array}$} & \multirow[t]{5}{*}{$\begin{array}{l}8 \\
1,2,3,4 \\
-\end{array}$} \\
\hline & & & NS & 100 & 27.8 & 0 & & \\
\hline & & & 0.23 & 65 & 77.0 & 16.8 & & \\
\hline & & & 0.51 & 121 & 76.9 & 11.7 & & \\
\hline & & & 0.84 & 78 & 101 & 13.4 & & \\
\hline \multirow[t]{3}{*}{31} & $\begin{array}{l}\text { 4-ABP-Hb } \\
\text { (blood) }\end{array}$ & BERNERT et al. & $\begin{array}{l}\text { "Tar" (FTC) } \\
\text { (mg/cig) }\end{array}$ & $\mathrm{N}$ & $\begin{array}{l}\text { 4-ABP-Hb } \\
(\mathrm{pg} / \mathrm{g} \mathrm{Hb})\end{array}$ & $\begin{array}{l}\text { CPD } \\
(\mathrm{cig} / \mathrm{d})\end{array}$ & \multirow{3}{*}{$\begin{array}{l}\text { Dataset (Model) \#: } \\
\text { Tables: } \\
\text { Figures: }\end{array}$} & \multirow{3}{*}{$\begin{array}{l}8 \\
1,2,3,4 \\
-\end{array}$} \\
\hline & & & 10 & 40 & 104.4 & n.r. & & \\
\hline & & & 15.8 & 110 & 104.3 & n.r. & & \\
\hline
\end{tabular}


Selected studies with reported data used for the regression analyses. ${ }^{a, b}$ (contd.)

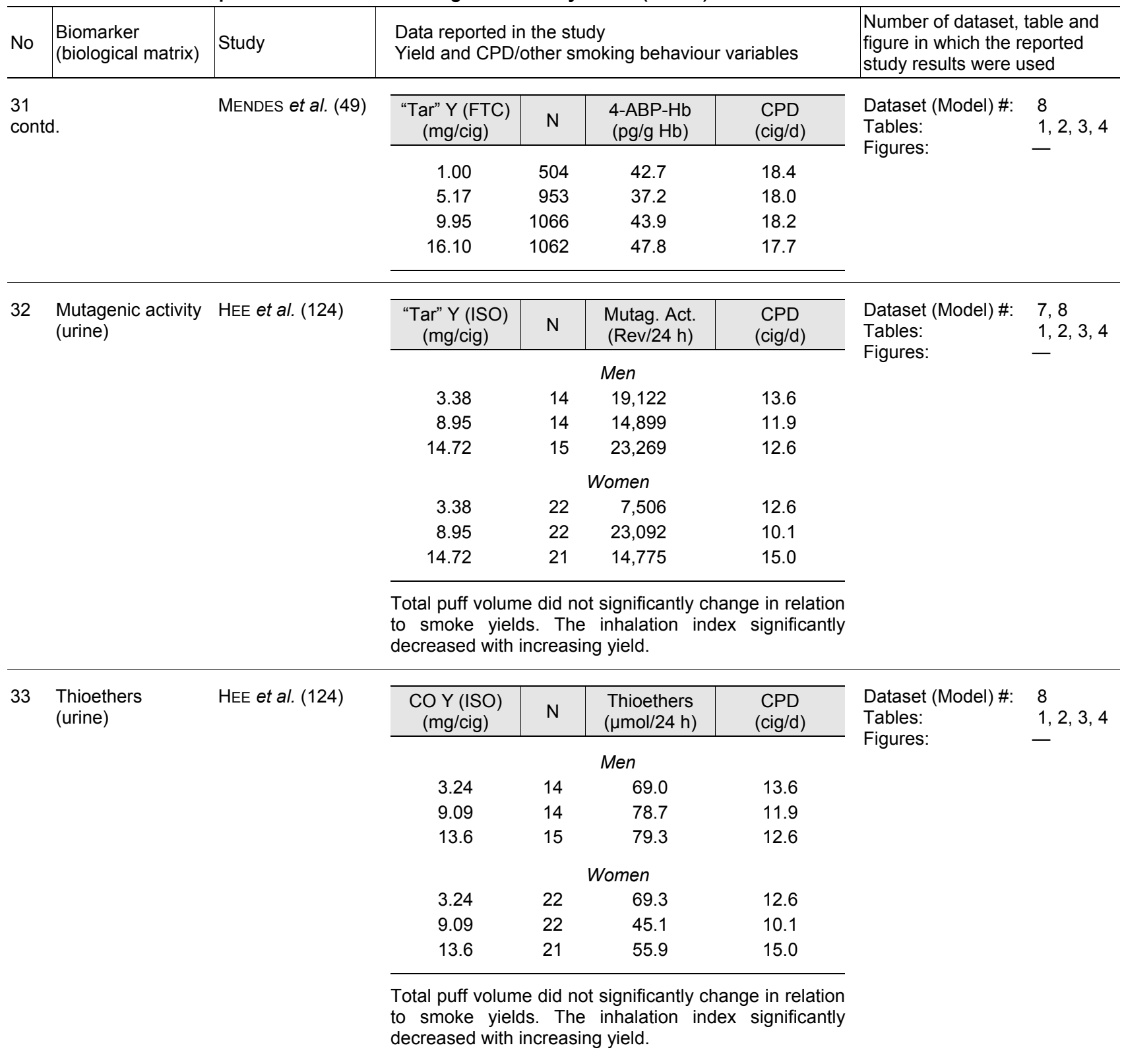

\begin{tabular}{|c|c|c|c|}
\hline \multicolumn{4}{|l|}{ a Abbreviations } \\
\hline 1-(2- etc.) $\mathrm{OH}-\mathrm{Phe}$ & 1- (2- etc.) Hydroxyphenanthrene & MHBMA & Monohydroxybutenyl-mercapturic acid \\
\hline 1-OH-Nap & 1-Hydroxynaphthalene & $\mathrm{N}$ & Number \\
\hline 1-OH-Pyr & 1-Hydroxypyrene & NNAL & 4-(methylnitrosamino)-1-(3-pyridyl)-1- \\
\hline 2-OH-Flu & 2-Hydroxyfluorene & & butanol \\
\hline 2-OH-Nap & 2-Hydroxynaphthalene & NNAL-gluc & NNAL-glucuronide \\
\hline 4-ABP-Hb & Hemoglobin adduct of 4-aminobiphenyl & $\mathrm{Nic}$ & Nicotine \\
\hline \multirow[t]{2}{*}{ AAVal-Hb } & Carbamoylethylvaline (hemoglobin & $\mathrm{Nic}+2$ & Nicotine + cotinine $+\mathrm{OH}-\mathrm{Cot}$ \\
\hline & adduct of acrylamide) & $\mathrm{Nic}+5$ & Nicotine equivalents in urine (nicotine, \\
\hline Acr & Acrolein & & cotinine, $\mathrm{OH}-\mathrm{Cot}$ and their respective \\
\hline \multirow[t]{2}{*}{ CeVal-Hb } & 2-Cyanoethylvaline ((hemoglobin & & glucuronides) \\
\hline & adduct of acrylonitrile) & $\mathrm{Nic}+7$ & Nic $+5+$ nicotine- $N$-oxide + cotinine- $N$-oxide \\
\hline $\mathrm{CO}$ & Carbon monoxide & $\mathrm{Nic}+8$ & Nic $+7+$ norcotinine \\
\hline COex & Carbon monoxide in exhaled breath & n.r. & Not reported \\
\hline $\mathrm{COHb}$ & Carboxyhemoglobin & NS & Non-smokers \\
\hline Cot & Cotinine & $\mathrm{OH}-\mathrm{Cot}$ & trans-3'-Hydroxycotinine \\
\hline Cot-gluc & Cotinine glucuronide & OHEtVal-Hb & 2-Hydroxyethylvaline (hemoglobin adduct of \\
\hline CPD & Cigarettes per day & & ethylene oxide) \\
\hline DHBMA & Dihydroxybutyl-mercapturic acid & $\mathrm{P}$ & Plasma \\
\hline FTC & Federal Trade Commission (USA) & Pyr & Pyrene \\
\hline FTND & Fagerstrom test for nicotine dependence & Rev & Revertants \\
\hline $\mathrm{HCN}$ & Hydrogen cyanide & Sal & Saliva \\
\hline HPMA & 3-Hydroxypropyl-mercapturic acid & SCN & Thiocyanate \\
\hline ISO & Int. Organization for Standardization & SPMA & S-Phenyl-mercapturic acid \\
\hline \multirow[t]{2}{*}{ MeVal-Hb } & Methylvaline (hemoglobin adducts of & ttMA & trans,trans-Muconic acid \\
\hline & methylating agents) & Y & Yield \\
\hline
\end{tabular}


Criteria for selection/inclusion of studies: (1) 2 Cigarettes types with different yields; (2) biomarker/yield of precursor (or surrogate) data presented; (3) CPD given or considered in data

Mean of yield range is used

Groups 1, 3 and 5 from study Period 1 were considered for evaluation

Estimated from reported data

Nicotine equivalents represent the molar sum of nicotine and various numbers of its major metabolites $(\mathrm{Nic}+2, \mathrm{Nic}+5$, etc., see Abbreviations for specifications)

$g$ Only Day 8 of the study and smokers of conventional cigarettes were considered for evaluation 